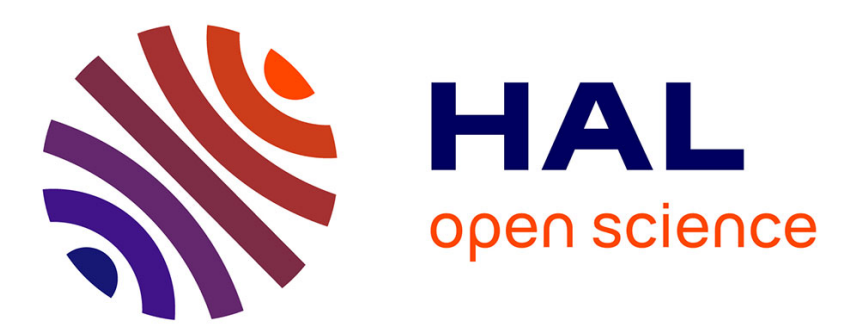

\title{
Photoreceptor cell replacement in macular degeneration and retinitis pigmentosa: a pluripotent stem cell-based approach
}

Giuliana Gagliardi, Karim Ben M'Barek, Olivier Goureau

\section{To cite this version:}

Giuliana Gagliardi, Karim Ben M'Barek, Olivier Goureau. Photoreceptor cell replacement in macular degeneration and retinitis pigmentosa: a pluripotent stem cell-based approach. Progress in Retinal and Eye Research, 2019, 71, pp.1-25. 10.1016/j.preteyeres.2019.03.001 . hal-02301567

\section{HAL Id: hal-02301567 \\ https: / hal.sorbonne-universite.fr/hal-02301567}

Submitted on 30 Sep 2019

HAL is a multi-disciplinary open access archive for the deposit and dissemination of scientific research documents, whether they are published or not. The documents may come from teaching and research institutions in France or abroad, or from public or private research centers.
L'archive ouverte pluridisciplinaire HAL, est destinée au dépôt et à la diffusion de documents scientifiques de niveau recherche, publiés ou non, émanant des établissements d'enseignement et de recherche français ou étrangers, des laboratoires publics ou privés. 
Photoreceptor cell replacement in macular degeneration and retinitis pigmentosa: a pluripotent stem cell-based approach

Giuliana Gagliardi ${ }^{1}$, Karim Ben M'Barek $^{2}$ and Olivier Goureau ${ }^{1}$

${ }^{1}$ Institut de la Vision, Sorbonne Université, INSERM, CNRS, F-75012 Paris, France

${ }^{2}$ Institute for Stem Cell Therapy and Exploration of Monogenic diseases, CECS, AFM, INSERM, F-91100 Corbeil-Essonnes, France.

Corresponding author: Olivier Goureau

Institut de la Vision, 17, Rue Moreau 75012 Paris, France

Email: olivier.goureau@inserm.fr

Tel: (33) 1.53.46.25.33 Fax: (33) 1. 44. 53.46.26.00 


\begin{abstract}
The human retina fails to regenerate and cell-based therapies offer options for treatment of blinding retinal diseases, such as macular degeneration and retinitis pigmentosa (RP). The last decade has witnessed remarkable advances in generation of retinal cells and retinal tissue from human pluripotent stem cells (PSCs). The development of 3D culture systems allowing generation of human retinal organoids has substantially increased the access to human material for future clinical applications aiming at replacing the lost photoreceptors in retinal degenerative diseases. This review outlines the advances that have been made toward generation and characterization of transplantable photoreceptors from PSCs and summarizes the current status of PSC-based preclinical studies for photoreceptor replacement conducted in animal models. Considering the recent turning point in our understanding of donor photoreceptor integration, this review focuses on the most crucial obstacles that hinder the photoreceptor replacement, discusses the most promising strategies to overcome them in the future, and provides a perspective on the approaching advancement in the application of PSC technology for treatment of photoreceptor degenerative diseases.
\end{abstract}

\title{
Keywords
}

Cell therapy

Induced Pluripotent stem cells

Retinal degeneration

Retinal development

Retinal organoids

Transplantation 
Table of Contents

\section{Introduction}

1.1 Macular degeneration and Retinitis Pigmentosa

1.2 Therapeutic strategies for photoreceptor degenerative diseases

\section{Retinal development}

2.1 Eye field specification and optic vesicle formation

\subsection{Differentiation of the neural retina}

\subsection{Photoreceptor specification and differentiation}

\section{Generation of photoreceptors from human ESCs and iPSCs}

3.1 Pioneering work on retinal and photoreceptor differentiation

3.2 Moving to 3D-based protocols: retinal organoids

3.3 Moving to future cell therapy products: Good Manufacturing Practices-compliant protocols

\subsection{Accelerating photoreceptor generation from human ESCs and iPSCs}

\section{Transplantation of ESC and iPSC-derivatives for retinal repair}

4.1 PSC-derived neural progenitors for retinal transplantation

4.2 PSC-derived retinal cells for photoreceptor replacement

4.3 Change of perspective on donor photoreceptor integration

4.3.1 Demonstration of cytoplasmic material exchange following transplantation

4.3.2 Cytoplasmic material exchange with mouse PSC-derived photoreceptors

\subsubsection{Identification of human cell following xeno-transplantation}

4.3.4 Cytoplasmic material exchange with human PSC-derived photoreceptors

4.4 Isolation and transplantation of photoreceptors derived from PSCs

4.4.1 Selection of mouse photoreceptor precursors by targeting different cell surface antigens 
4.4.2 Specific photoreceptor cell surface antigens to isolate transplantable photoreceptor precursors

\subsection{Transplantation of PSC-derived retinal sheets}

4.5.1 Transplantation of mouse PSC-derived retinal sheets

4.5.2 Transplantation of human PSC-derived retinal sheets

4.6 Toward long-term survival: the role of immune response following photoreceptor transplantation

5. Future directions and conclusion 


\section{Footnotes: Abbreviations}

age-related macular degeneration (AMD); adeno-associated virus (AAV); Bone morphogenetic protein (BMP); Cone-rod homeobox (Crx); Dickkopf-1 (Dkk-1); eye-field transcription factors (EFTFs); electroretinogram (ERG); embryoid bodies (EBs); embryonic stem cells (ESCs); Fluorescence activated cell sorting (FACS); Fibroblast growth factor (FGF); Fluorescence in situ hybridization (FISH); Green Fluorescent protein (GFP); G Protein Subunit Alpha Transducin 1(Gnat1); Good Manufacturing Practices (GMP); induced pluripotent stem cells (iPSCs); Inner Nuclear Layer (INL); Insulin-like growth factor (IGF); Magnetic-activated cell sorting (MACS); Microphthalmia-associated transcription factor (Mitf); multielectrode arrays (MEA); Neural retina leucine zipper (Nrl); Non-human primates (NHPs); Outer Nuclear Layer (ONL); Optic Vesicle (OV); Orthodenticle homeobox 2 (Otx2); Paired box protein 6 (Pax6); Pluripotent stem cells (PSCs); Retina and anterior neural fold homeobox (Rax); retinal ganglion cells (RGCs); Retinal pigment epithelium (RPE); Retinal progenitor cells (RPCs); Retinitis Pigmentosa (RP); Retinoic acid (RA); Retinoid-related orphan nuclear receptor $\beta$ (ROR $\beta$ ); Royal College of Surgeons (RCS); Serum-free floating embryoid bodies (SFEB); Sonic hedgehog (Shh); Transforming growth factor $\beta$ (TGF $\beta$ ); Visual system homeobox 2 (Vsx2); Wingless-Int (Wnt) 


\section{Introduction}

Vision is among the most important senses enabling major activities of daily living; it makes visual impairment or blindness a major handicap that profoundly impacts the life of over 200 million people worldwide (Bourne et al., 2017; Flaxman et al., 2017). The retina that lines the back of the eye is the light-sensitive neuronal tissue comprising multiple layers of distinct cell types. Most forms of untreatable blindness result from the death of these retinal neurons. The destruction of the retinal ganglion cells (RGCs) in glaucoma causes loss of vision in more than 5 million people worldwide. Retinal diseases caused by the death of photoreceptors and/or supporting retinal pigment epithelium (RPE) cells, such as diabetic retinopathies and age-related macular degeneration (AMD) are an increasing significant cause of incurable sight loss. By 2020, among the global population with moderate or severe visual impairment (240 million), the number of people affected by AMD and diabetic retinopathies is anticipated to rise to around to 9 and 3.5 million respectively (Flaxman et al., 2017; Mitchell et al., 2018). In addition, inherited retinal dystrophies (IRD) in which the photoreceptors die are another major cause of irreversible blindness worldwide (Berger et al., 2010; Verbakel et al., 2018). This group of genetic diseases -including Stargardt disease, retinitis pigmentosa (RP), Leber congenital amaurosis (LCA) and Usher syndrome- can arise from mutations in more than 200 different genes and presents high genetic heterogeneity.

\subsection{Macular degeneration and Retinitis Pigmentosa}

Rod photoreceptors, responsible for vision under dim light conditions, represent the vast majority of photoreceptors (95\%) in the human retina, while the $5 \%$ of cone photoreceptors are responsible for daylight vision. According to their light sensitivity, three types of cones (red, green and blue) are found in primates, permitting a trichromatic color vision. The rodfree fovea that lies in the middle of the macular area of the retina contains almost exclusively 
cones, while rods are located more peripherally. Monogenic diseases of the retina affect more than 2 million people worldwide (Haider et al., 2014; Hartong et al., 2006). Depending on the predominant type of photoreceptor involved, it is possible to discriminate cone-rod dystrophies, rod-cone dystrophies and generalized photoreceptor diseases, in which both cell types are affected (Figure 1). For each group of diseases, the ocular phenotype can be associated with symptoms affecting other tissues, corresponding to syndromic forms, and the mode of inheritance can be dominant, recessive, or X-linked (Berger et al., 2010; Hamel, 2006; Hartong et al., 2006).

Cone-dominated diseases, such as macular degenerations, cone and cone-rod dystrophies lead to severe visual impairment. Macular dystrophies are characterized by a disease restricted to the macula, whereas pure cone and cone-rod dystrophies are defined by a generalized cone dystrophy affecting both macular and peripheral cones, and a characteristic decrease in both cone or cone and rod responses at full field electroretinogram (ERG). Currently, about 20 genes have been shown to be responsible for non-syndromic progressive cone-rod dystrophies and 10 different genes were associated with monogenic macular dystrophies (Berger et al., 2010; Haider et al., 2014) (Figure 1). Stargardt disease (with its phenotypic variant fundus flavimaculatus), which has autosomal recessive inheritance, is the most common form of inherited juvenile macular degeneration ( 1 in 8,000 to 10,000 individuals) that is due to mutations in the ATP-binding cassette transporter (ABCA4) gene (Allikmets et al., 1997). Rare cases of Stargardt-like disease inherited as a dominant trait are due to mutations in the Elongation Of Very Long Chain Fatty Acids 4 (ELOVL4) gene (Haji Abdollahi and Hirose, 2013). Cones can also be affected in stationary disorders as part of cone dysfunction syndromes, the most common form of which is achromatopsia (complete and incomplete) (Zeitz et al., 2015). 
The most common form of rod-dominated diseases is retinitis pigmentosa (RP), also known as rod-cone dystrophy (Figure 1). RP is a term given to a set of clinically similar phenotypes associated with genetically heterogeneous causes (Hartong et al., 2006; Verbakel et al., 2018). Even though the onset and the progression of the disease vary between patients, typical symptoms include night blindness followed by visual field constriction, resulting in tunnel vision and leading, in many cases, to complete blindness due to the secondary loss of cones in later stages (Hamel, 2006; Hartong et al., 2006). The worldwide prevalence of RP is estimated at about 1 in 4000 people, for a total of 1.5 million affected individuals (Hartong et al., 2006; Verbakel et al., 2018). Among the most frequent syndromic forms of RP, Usher syndrome characterized by hearing loss and visual impairment and in some forms vestibular dysfunctions- accounts for about 20\% of all RP cases (Mathur and Yang, 2015). Bardet-Biedl syndrome is another syndromic RP that presents with hexadactyly, obesity, mental retardation and in some cases kidney disease. Mutations in 16 genes are known to cause Usher syndrome, while mutations in 18 genes cause Bardet-Biedl syndrome (Mathur and Yang, 2015; Mockel et al., 2011). Disease-causing mutations can be inherited in autosomal recessive (50 to 60\%), autosomal dominant (30 to $40 \%$ ) or X-linked (5 to 15\%) manner, and mutations in several genes can be either dominant or recessive. High-throughput "next-generation sequencing" approaches have allowed to identify novel RP genes and new mutations; more than 60 genes have been found involved in non-syndromic RP and more than 3000 mutations have been reported in these genes (Berger et al., 2010; Daiger et al., 2013). According to the presumed function of the encoded protein, the different RP-associated genes have been categorized into four major groups: phototransduction, retinal metabolism, cellular structure and splicing (Berger et al., 2010; Daiger et al., 2013). Most disease-causing gene mutations are specifically expressed in photoreceptors, such as Rhodopsin, which is the most commonly mutated RP gene $(25 \%$ of the autosomal dominant cases). Few genes are specifically expressed in the 
RPE, such as the genes coding for MER Proto-Oncogene Tyrosine Kinase (MERTK), Lecithin Retinol Acyltransferase (LRAT) or Retinol Dehydrogenase 5 (RDH5). As expected, mutations in one of these genes lead to dysfunction of the RPE (absence of photoreceptor outer segments phagocytosis, absence of re-isomerization of the retinal...) and, subsequently, to the death of photoreceptors. Interestingly, the genes coding for the pre-mRNA processing factor 3 (PRPF3), PRPF8 and PRPF31, implicated in around 10\% of the autosomal dominant cases, are ubiquitously expressed, although the phenotype of patients is restricted to the retina (Liu and Zack, 2013). Since the splicing activity is essential in almost all cell types, it is not clear why mutations in PRPF genes cause only a retina-specific disease and which is the specific retinal cell type(s) originally altered by these mutations. Although the functional properties of several RP-associated genes have largely been studied, the phenotype-genotype correlations yet not fully understood- remain to be further elucidated as a critical step in the diagnosis of RP.

In the group of generalized photoreceptor diseases (Figure 1), Leber congenital amaurosis (LCA) is one of the most common causes of blindness in children (frequency estimated at 2 to 3 per 100,000 newborns) (den Hollander et al., 2008; Haider et al., 2014). Currently, more than 25 genes were identified to carry mutations in LCA patients, with a mode of inheritance mostly autosomal recessive. Among these genes, around 50 mutations have been reported to cause LCA in each of four major genes coding for Centrosomal protein 290kDa (CEP290), Crumbs Family Member 1 (CRB1), Guanylate cyclase 2D (GUCY2D) and the RPE-Specific Protein 65kDa (RPE65) (den Hollander et al., 2008). Choroideremia (causal mutation in the gene coding for Rab escort protein-1) and Gyrate atrophy (causal mutation in the gene producing the enzyme ornithine aminotransferase) are two other major forms of nonsyndromic generalized photoreceptor diseases with an estimated incidence rate of 1:50,000 to 1:100,000 (Berger et al., 2010; Haider et al., 2014). 
In contrast to IRD, AMD is a multifactorial disease first affecting cone photoreceptors and caused by a combination of environmental and genetic risk factors (Ferris et al., 2013; Fritsche et al., 2013; Guillonneau et al., 2017). Genome-wide association studies have identified more than 30 different risk variants as well as major environmental risk factors including aging, smoking, sunlight exposure, body mass index and cardiovascular diseases. Early AMD is characterized by thickening of the Bruch's membrane and deposits under the RPE. In more advanced stages, the disease is generally subdivided into non-neovascular AMD (dry, atrophic AMD) and neovascular AMD (wet AMD), based respectively on the absence or presence of blood vessels growing from the choroid toward the retina (Ferris et al., 2013). Different clinical features can be observed in patients affected by dry or wet AMD but the resulting damage to the macular region leads, in both conditions, to a loss of vision in the central visual field in a large number of patients.

\subsection{Therapeutic strategies for photoreceptor degenerative diseases}

Despite their very different etiologies, the various retinal diseases mentioned above lead to the same end-result, namely the loss of photoreceptors. Since currently available treatments, such as the delivery of neurotrophic factors or anti-angiogenic agents, are limited to delaying the onset or slowing down the progress of visual impairment, extensive research efforts have recently focused on the development of novel therapeutic strategies, including gene and cell therapies. Indeed, the eye represents an ideal target for both gene and cell therapies because it is easily accessible and small (thus low volume of virus or cells would be sufficient for therapy), highly compartmentalized (permitting specific targeting of different ocular tissues) and separated from the rest of the body by the blood-retinal barrier (ensuring ocular immune privilege and minimal systemic dissemination). Lastly, the development of high-resolution 
and non-invasive imaging approaches, such as optical coherence tomography and adaptive optics, is of great value in evaluating the retinal changes after treatments.

In the last two decades, different strategies for gene therapy aiming at correcting the causative gene mutations (gene supplementation vs. endogenous gene suppression) have been developed in models of RP using mainly adeno-associated virus (AAV) or lentivirus as viral vectors, and promising results from animal studies (mouse, rat, dog) have paved the way toward first applications in humans. Since the approval of the first successful ocular gene therapy, by gene supplementation of RPE65 in patients with LCA, many clinical trials with gene therapies for IRD have been launched in the last two years (Dias et al., 2018; Verbakel et al., 2018). However, gene therapy to silence or replace a mutated gene would not be effective in retinal degenerative diseases associated with significant cell damage. For late stage diseases, when photoreceptor degeneration is too advanced, more suitable strategies aiming at restoring the light-sensitivity of the retina are currently investigated. These include optogenetic tools and photosensitive switches, two techniques allowing to induce lightsensitivity in remaining retinal neurons (dormant cones or inner retinal neurons) either by genetic introduction of microbial opsins, or the use of chemical photoswitches (Busskamp et al., 2012; Van Gelder, 2015; Yue et al., 2016). Another strategy to bypass photoreceptor activity consists in the insertion of bioelectronic prosthesis for external electrical stimulation of the remaining inner retinal neurons or RGCs (Cheng et al., 2017; Yue et al., 2016). Both epiretinal and subretinal implants, according to their ocular implantation, have already entered in clinical trial and practice now (Cheng et al., 2017; Dias et al., 2018; Yue et al., 2016). Unlike optogenetics and retinal protheses, cell therapy attempts at recreating the preexisting functional retinal system by replacing the degenerated cells with new cells. One of the main advantages of cell therapies is that they are mutation-independent and can be used in a wide range of retinal degenerative conditions. Over the past two decades, pluripotent stem cells 
have appeared as an attractive source of cells in regenerative medicine, due to the fact that they can be maintained indefinitely in an undifferentiated state in vitro and can differentiate into cells from all the three germ layers (endoderm, mesoderm, ectoderm). Human embryonic stem cells (ESCs) have been the best studied since their first isolation from the inner cell mass of a blastocyst (Thomson et al., 1998). In 2007, the group of S. Yamanaka generated another type of pluripotent stem cell by reprogramming human fibroblasts with four specific transcription factors, POU class 5 homeobox 1 (POU5F1, also known as OCT4), SRY (sex determining region Y)-box 2 (SOX2), Kruppel-like factor 4 (KLF4) and myc proto-oncogene protein (c-MYC) (Takahashi et al., 2007). These induced pluripotent stem cells (iPSCs) possess almost the same features as ESCs and represent an incredibly promising source of autologous cells for transplantation purposes. Following this original discovery, numerous studies reported the ability of different somatic cell types (such as keratinocytes or blood cells) to be reprogrammed and the development of non-integrative delivery methods (such as episomal plasmids or RNA) for reprogramming (González et al., 2011; Karagiannis et al., 2019).

The differentiation of mouse ESCs and also of human ESCs and iPSCs toward retinal lineages has progressed rapidly in the last decade. There has been a massive effort in recent years to differentiate RPE from human pluripotent stem cells for use in transplantation studies, and different groups reported encouraging morphological and functional results in animal models of retinal degeneration after transplantation of RPE cells, as nicely reviewed recently (Jones et al., 2017; Leach and Clegg, 2015; Nazari et al., 2015). Based on studies in animals, clinical trials for macular degeneration have started with the idea to replace the lost or dysfunctional RPE in AMD patients with healthy RPE cells derived from ESCs or iPSCs (Chichagova et al., 2018; Dalkara et al., 2016). First phase I/II trials sponsored by Astellas Pharma (formerly Ocata Therapeutics) were launched to evaluate the safety and tolerability of a subretinal 
injection of human ESC-derived RPE as cell suspension in patients with advanced dry AMD and Stargardt's disease (Mehat et al., 2018; Schwartz et al., 2015; Song et al., 2015). Safety and tolerability prospective clinical trials are also currently underway to evaluate subretinal injection of human ESC- or iPSC-derived RPE cell sheets (da Cruz et al., 2018; Kashani et al., 2018; Mandai et al., 2017b).

While RPE replacement alone may be used for specific disease indications, transplantation of photoreceptors -as a retinal sheet or as a suspension of dissociated cells- is required after extensive photoreceptor degeneration. Integration into the host retina and reconstruction of the neural circuitry and functionality are the major hurdles for successful cell transplantation. Prior studies in animal models revealed that photoreceptor transplantation is feasible when the donor cells are at a correct ontogenetic stage at the time of transplantation, corresponding to post mitotic committed photoreceptors (Pearson, 2014; Santos-Ferreira et al., 2017). Initial transplantation studies with photoreceptor precursor cells in different blind rodent models led the investigators to conclude that transplanted cells can survive within the degenerating retina, differentiate into partially mature photoreceptors, form some synaptic connections and that this functional integration could lead to visual improvement (Barber et al., 2013; Eberle et al., 2012; MacLaren et al., 2006; Pearson et al., 2012; Santos-Ferreira et al., 2015; Singh et al., 2013). However, with the very recent identification of cytoplasmic material exchange between donor and host photoreceptors (see chapter 5.3), former findings assuming donor cell integration in the host retinal circuitry with correct synaptic contacts need to be revisited (Nickerson et al., 2018; Santos-Ferreira et al., 2017).

In the following chapters, we focus our attention on recent advances in generating transplantation-competent cells from human pluripotent stem cell sources and discuss cell transplantation-based therapies using pluripotent stem cell-derived retinal cells for replacing dead or dying photoreceptors. 


\section{Retinal development}

The knowledge of eye development is the basis of regenerative medicine for retinal diseases. Indeed, the understanding of the regulatory pathways of eye development and retinal specification provides an important context for the development of robust and reliable protocols for generation of retinal cells from pluripotent stem cells. In this chapter, we describe the key steps of eye development, with specific emphasis on molecular and cellular mechanisms involved in photoreceptor specification and differentiation.

\subsection{Eye field specification and optic vesicle formation}

During embryogenesis, the eye of vertebrates is derived from three types of tissue: retina and RPE arise from the neural ectoderm, cornea and lens from the surface ectoderm, and sclera from the mesoderm. The eye formation initiates during gastrulation in connection with the induction and patterning of the neuroepithelium. A series of patterning events governed by specific signals lead to eye specification of a group of neuroepithelial cells within the midline of the anterior neural plate. Fundamental experiments from the last decades in different species (Graw, 2010; Zuber, 2010) demonstrated that the delimitation of the eye field territory is promoted by fibroblast growth factor (FGF) and insulin-like growth factor (IGF) signals and by repression of transforming growth factor $\beta$ (TGF $\beta$ )/bone morphogenetic protein (BMP) and Wingless-Int (Wnt) pathways. Secretion of endogenous antagonists such as Noggin/Chordin and Dickkopf lead respectively to the inhibition of the TGF $\beta / B M P$ and Wnt pathways, at the level of the presumptive eye field (Figure 2). At molecular level, this territory is characterized by the coordinated expression of specific intrinsic determinants called "eye-field transcription factors" (EFTFs). These specific transcription factors code for five different homeobox proteins (see below), one nuclear receptor $(\mathrm{Nr} 2 \mathrm{e} 1$, also known as 
Tlx), and one T-box protein (Tbx3), whose expression temporally and spatially overlap. The homeobox transcription factors LIM homeobox protein 2 (Lhx2), orthodenticle homeobox 2 (Otx2), paired box 6 (Pax6), Retina and anterior neural fold homeobox (Rax), sine oculisrelated homeobox 3 (Six3) and sine oculis-related homeobox 6 (Six6) act synergistically to form and maintain the eye field territory in a self-regulating feedback highly conserved between species (Zuber, 2010). Interestingly, pluripotent cells isolated from the xenopus pole of blastula-stage embryos misexpressing the EFTFs were able to generate eyes that were molecularly and functionally similar to the normal eye (Viczian et al., 2009).

During midline formation, the single eye field separates giving rise to two optic areas. Following eye field formation in each of these two areas, the neuroepithelium of the ventral forebrain (diencephalon) evaginates, resulting in the formation of optic vesicles. In the early optic vesicle all cells co-express the EFTFs and are competent to form neural retina, RPE or optic stalk. The specification of the neural retina and RPE domains takes place during the evagination process, with signaling molecules that coordinate the expression of intrinsic factors, allowing ultimately the differentiation of the cells in a specific lineage depending on their initial regionalization. The lens placode (that originates from the surface ectoderm after contacting the distal portion of the optic vesicle) invaginates into optic vesicle resulting in formation of the lens vesicle and the optic cup. The inner surface of the optic cup corresponds to the future neural retina, while the RPE emerges from the outer part of the optic cup. Exogenous signals coming from adjacent tissues influence the early specification of the optic vesicle into neural retina and RPE (Figure 2). FGF signal from the overlying lens ectoderm normally inhibits RPE specification and promotes neural retina lineage, while specification of the RPE requires input from the surrounding extra-ocular mesenchyme by members of the TGFß/BMP superfamily (Fuhrmann, 2010; Fuhrmann et al., 2014). These extrinsic cues regulate the expression of a specific set of transcription factors that are important for the 
development of the cell type in which they are expressed: the expression of the transcription factor Visual system homeobox 2 (Vsx2), also named Chx10, delineates the future neural retina, while the future RPE expresses the transcription factor Microphthalmia-associated transcription factor (Mitf) and the optic stalk expresses the paired box protein 2 (Pax2) (Adler and Canto-Soler, 2007; Fuhrmann et al., 2014). Reciprocal transcriptional repression between these transcription factors contributes to the establishment of boundaries between these developing territories.

\subsection{Differentiation of the neural retina}

Within the optic vesicle / cup, the neural retina is generated from common multipotent retinal progenitor cells (RPCs) expressing Vsx2 and Pax6. This will give rise to all types of cells in an orderly manner that is generally conserved among species. Retinal ganglion cells, amacrine and horizontal cells and cone photoreceptors are generated at relatively early stages, while rod photoreceptors, bipolar and Müller cells differentiate mainly at later stages (Turner and Cepko, 1987; Young, 1985). The widely accepted competence model of retinal histogenesis hypothesizes that RPCs progress through a competence time window during which they can generate specific cell types (Cepko, 2014). Recent live imaging studies consistent with a stochastic model (Gomes et al., 2011; He et al., 2012) suggest that RPCs can choose from multiple cell fate at any time, even though the transition of competence occurs in an unidirectional way (Boije et al., 2014). Several lines of evidence demonstrate that transcription factors expressed in RPCs, such as bHLH-type and homeobox-type factors, are required for the correct specification of retinal cell types (Bassett and Wallace, 2012; Livesey and Cepko, 2001; Ohsawa and Kageyama, 2008). A core transcriptional hierarchy is the basis of the molecular decisions made by the RPCs to acquire specific retinal fates. As nicely reviewed by Boije et al. (2014), expression of Vsx2 in proliferative RPCs allows the 
inhibition of transcription factors influencing specific cell fate such as Atonal bHLH transcription factor 7 (Atoh7; also known as Math5), Forkhead box N4 (FoxN4), Pancreas specific transcription factor 1a (Ptf1a) and Visual system homeobox 1 (Vsx1). As the development progresses this inhibition is abolished, and depending on the level of Atoh7 (promoting RGC lineage) and the presence or not of FoxN4 and Ptfla (promoters of amacrine and horizontal cells lineages), each RPC follows different paths giving rise to different cell fates. Loss of Atoh7 in RPCs provides a permissive environment in absence of FoxN4 and Ptfla for a photoreceptor fate (Bassett and Wallace, 2012; Boije et al., 2014).

\subsection{Photoreceptor specification and differentiation}

The process of photoreceptor development can be divided into different successive steps: initial specification and commitment of RPCs toward a photoreceptor cell fate after final mitosis followed by choice of cone or rod cell fate and, finally, selection of a sub-type of cones, corresponding to the maturation of photoreceptors with expression of photoreceptorspecific genes and outer segments biogenesis (Figure 2). Several intrinsic factors have been identified together with their gene regulation network, leading to a model in which differentiation into type S cones would be the default pathway (Brzezinski and Reh, 2015; Swaroop et al., 2010). The down regulation of Notch signaling and the implication of proneural genes, such as achaete-scute homologue 1 (ASCL1; also known as Mash1) and Neuronal differentiation 1 (NeuroD1) could be the earliest molecular mechanisms that prompt RPCs to adopt a photoreceptor fate over other cell fates (Hatakeyama and Kageyama, 2004; Jadhav, 2006). The coordinated action of six major transcription factors is required for the RPC commitment to rod or cone photoreceptor cell fate (Brzezinski and Reh, 2015; Swaroop et al., 2010): Cone-Rod homeobox (Crx), Otx2, neural retina leucine zipper (Nrl), orphan 
nuclear receptor Nr2e3, Retinoid-related orphan nuclear receptor $\beta(\operatorname{ROR} \beta)$ and Thyroid hormone receptor $\beta 2$ (THR $\beta 2$ ).

Otx2 is expressed in RPCs undergoing their final mitotic division and in early photoreceptor precursors, while Crx starts to be expressed in these post-mitotic committed precursors and its presence is important for the terminal differentiation of photoreceptors (Chen et al., 1997; Furukawa et al., 1997; Koike et al., 2007; Nishida et al., 2003). Otx2 biases the RPC to photoreceptor precursor fate and activates the expression of Crx; the combination of these two transcription factors is necessary and sufficient to induce the photoreceptor cell fate (Hennig et al., 2008; Nishida et al., 2003). Recent studies in mice have reported the role of photoreceptor domain zinc finger protein 1 (Prdm1), also known as Blimp1, in maintaining RPCs expressing Otx2 in the photoreceptor lineage (Brzezinski et al., 2013; Katoh et al., 2010). Prdm1 had the ability to repress genes involved in the specification of bipolar cells within Otx2-positive RPCs, stabilizing the commitment of these Otx2-expressing precursors to photoreceptor fate. The nuclear receptor ROR $\beta$ also plays a role in the specification of photoreceptors downstream Otx 2 and Onecut1 (OC1) and upstream of Nrl and Nr2e3. Ror $\beta$ participates in the induction of $\mathrm{Nrl}$ expression and the loss of function of ROR $\beta$ in the retina leads to a drastic decrease of rod number and to an increase in the population of cones, mainly non-functional since they lack of outer segments (Jia et al., 2009).

The transcription factor Nrl is a key player in the choice of RPCs to become rods or cones. Nrl can interact with Crx leading to a rod differentiation program (Akimoto et al., 2006; Mears et al., 2001). One of the direct transcriptional targets of $\mathrm{Nrl}$ is the nuclear receptor $\mathrm{Nr} 2 \mathrm{e} 3$ expressed in post-mitotic rod precursors (Oh et al., 2008). The Nrl-Nr2e3 complex can suppress the expression of cone-specific genes, leading to consolidation of the rod fate directed by Nrl (Chen, 2005; Cheng et al., 2006; Peng et al., 2005). Photoreceptor precursors can differentiate as cones only when $\mathrm{Nrl}$ and $\mathrm{Nr} 2 \mathrm{e} 3$ fail to act, corresponding to a low level of 
Nrl expression. In mouse and chicken, $\mathrm{OC} 1$ has been shown to act, together with Otx2, upstream $\mathrm{Nrl}$ as a repressor of early rod photoreceptor gene expression (Emerson et al., 2013). In these committed cone precursors, THR $\beta 2$ and its ligand triiodothyronine T3 induce $\mathrm{M}$ opsin and suppress $\mathrm{S}$ opsin expression (Ng et al., 2001). Other factors have been reported to be involved in $\mathrm{S}$ and $\mathrm{M}$ opsin patterning, including retinoid X receptor $\gamma(\mathrm{RXR} \gamma)$, Retinoidrelated orphan nuclear receptor $\alpha(\mathrm{ROR} \alpha)$ and Chicken ovalbumin upstream promoter (COUP) transcription factors (Fujieda et al., 2009; Roberts et al., 2005; Satoh et al., 2009). Owing to the advent of next-generation sequencing, we have gained a deeper and, at the same time, more global look at the transcriptional changes guiding the development of mouse and human retina (Aldiri et al., 2017; Hoshino et al., 2017; Mellough et al., 2019) or characterizing the rod and cone specific signature across mammalian retinas (Mustafi et al., 2016). Interestingly, Hoshino and colleagues compared the transcriptomic profiles of human and mouse retina during development, with mouse embryonic retina (E11-E16) correlating with human fetal retina at D52-D80 and postnatal P0-P4 mouse retina similar to D94-136 human fetal retina. Some genes exhibited a marked difference in their gene expression levels between the two species (Hoshino et al., 2017), such as DCC and NRTK1 (encoding respectively netrin and nerve growth factor receptors), confirming the necessity to investigate further the differences between human and mouse retinal development. These studies confirmed that the human retinal development basically occurs in three phases, each dominated by the emergence of specific cell types and the expression of specific genes: first progenitor cells and RGC production, then horizontal and amacrine cells and finally photoreceptors, bipolar cells and Müller glia. However, for all cell types, the morphological differentiation in the fovea is completed much earlier than in other regions of the retina. The differences in the timing of gene expression between central and peripheral retina should be considered when correlating temporal gene expression between human and mouse retina. The 
accelerated developmental timing in foveal formation may explain why rods are excluded from this region, as rods are among the last cell types to be generated (Hoshino et al., 2017). This type of study should provide significant help in dissecting and controlling gene networks associated with functional maturations of specific retinal cell types in human retina.

\section{Generation of photoreceptors from human ESCs and iPSCs.}

Protocols guiding human pluripotent stem cell differentiation have been developed during the last decade by mimicking the successive developmental steps in vitro (Table I). The concept consisted in determination of culture conditions that allow ESCs or iPSCs to adopt first a neuroectodermal identity, followed by eye field identity and their succeeding direction toward a neural retina lineage or a RPE lineage.

\subsection{Pioneering work on retinal and photoreceptor differentiation}

One of the first efficient protocols for generating neuroretinal cells has been developed in mouse ESCs by using factors normally required during anterior neural and retinal induction in vivo (Ikeda et al., 2005). It used a serum-free floating culture of embryoid bodies (called SFEB system) with addition of specific inducers: Lefty-A, a nodal antagonist, and Dickkopf-1 (Dkk-1), a Wnt antagonist that allowed the generation of ESC-derived rostral neuronal progenitors. The presence of serum and Activin-A in SFEB system, just before plating the cells, induced significant generation (25-30\%) of retinal progenitors co-expressing Pax6 and Rax. These cells did not efficiently differentiate into photoreceptor precursors unless they were cultured with embryonic retinal cells. Using this concept of sequential specification (anterior neurectoderm and eye field territory), the group of T. Reh reported the first production of retinal cells from human ESCs (Lamba et al., 2006). Neural induction was stimulated in SFEB system by addition of Dkk-1, Noggin (BMP antagonist) and IGF-1, and 
cells were plated on poly-D-lysine and Matrigel for further differentiation with the same combination of neural inducers in presence of FGF-2 and proneural medium supplements (B27 and N2). Under these conditions, the authors reported that almost $80 \%$ of the differentiated cells expressed the EFTFs after three weeks, with $10 \%$ average of photoreceptor precursors expressing $\mathrm{CRX}$, and less than $0.01 \%$ expressing mature markers of photoreceptors, S-Opsin and Rhodospin (Lamba et al., 2006).

Based on the so-called "Lamba protocol", combining suspension cultures (SFEB system) and adherent cultures (plating on different specific coating) in the presence of specific morphogens, other groups have made some changes to improve the generation of both retinal progenitors and their specification/differentiation into photoreceptors. Osakada and colleagues confirmed the importance of preventing BMP/TGF $\beta$ and WNT pathways in "neuronal-retinal commitment" by inhibition of the respective downstream signaling pathways, SMAD and $\beta$ Catenin pathways, using the chemical compounds SB431542 and CKI-7 (Osakada et al., 2008). The replacement of morphogens (Lefty-A and DKK1) by small molecules (SB431542 and CKI-7) appears of great importance for the development of retinal differentiation protocols to be used in the future clinical settings. Other small molecules such as Dorsomorphin and XAV939 have been also used instead of NOGGIN and DKK-1 to differentiate human iPSCs into retinal progenitors (Meyer et al., 2009). In the stepwise 3D/2D protocol (Lamba et al., 2006; Osakada et al., 2008), addition of factors known to be involved in photoreceptor differentiation during development has been evaluated after plating embryoid bodies (EBs) in order to improve the generation of photoreceptors. The presence of taurine and retinoic acid (RA) after 90 days of culture increased the number of CRX-and Rhodopsin-positive photoreceptors observed in cultures after 130 days (Osakada et al., 2009b). 
In agreement with these pioneering protocols, a variety of retinal differentiation protocols for human ESCs and iPSCs (Amirpour et al., 2012; Boucherie et al., 2013; Hirami et al., 2009; Krohne et al., 2012; Lamba et al., 2010; Mellough et al., 2012; Tucker et al., 2013; Yanai et al., 2013; Zhou et al., 2015) (Table I) demonstrated the requirement of preventing the endogenous activation of BMP/TGF $\beta$ and WNT pathways and the presence of IGF-1 or Insulin (a key compound of the N2 and B27 supplements) at early 3D stage of cultures. In some of these protocols, the differentiation of retinal progenitors into photoreceptors has been favored by the addition of specific factors, such as FGF1 and/or FGF2, triiodothyronine (also known as thyroid hormone T3) and Sonic hedgehog (Shh) (Amirpour et al., 2012; Mellough et al., 2012; Tucker et al., 2013; Yanai et al., 2013). Each of these compounds has been added in specific time windows during the 2D step of the process, when plated EBs were cultured in presence of taurine and RA with B27 and N2 supplements. Preferential differentiation toward S-cone photoreceptors was reported with the addition of Coco (Dand5), a member of the

Cerberus gene family, acting in synergy with IGF-1 (Zhou et al., 2015). In the presence of Coco, $60-80 \%$ of the cells corresponded to S-cone photoreceptors, while addition of thyroid hormone resulted in a mixed M/S-cone population. Another approach allowing the improvement of photoreceptor generation in the stepwise 3D/2D protocol of differentiation was the calibration of the size of the EBs in the 3D step (Yanai et al., 2013). Using sizecontrolled EBs (200 $\mu \mathrm{m}$ diameter and 1000 cells) followed by the addition of Taurine, FGF2 and T3 after EB plating on Matrigel, Yanai and colleagues have been able to generate more than $80 \%$ of CRX-positive cells after 17 days of culture (Yanai et al., 2013).

\subsection{Moving to 3D-based protocols: retinal organoids}

The stepwise 3D/2D method has been elegantly modified by the group of D. Gamm (Meyer et al., 2011) who added a third step of culture aiming at isolating the self-forming 
neuroepithelial structures. Following differentiation of EBs in cell suspension, cells were plated on laminin-coated plates, and neuroepithelial structures were then manually picked and further grown as suspension cultures again. The authors found that these human ESC and iPSC-derived neuroepithelial structures expressed all EFTFs and that the gene and protein expression profiles of the progenitors forming the vesicular structures reflected a differentiation state of retinal progenitors closed to the optic vesicle (OV) stage of retinal development (Meyer et al., 2011). In this study, it has been reported that early endogenous expression of DKK1 and NOGGIN in some pluripotent stem cell (PSC) lines was sufficient to induce the formation of OV-like structures without addition of small molecules antagonizing the BMP/TGF $\beta$ and Wnt pathways. Following isolation, floating OV-like structures continued to differentiate toward the photoreceptor lineage, with the expression of CRX and Recoverin between days 45-60 of culture and more mature photoreceptors expressing Rhodopsin or SOpsin after 100 days in culture (Meyer et al., 2011; Phillips et al., 2012). Recently, adaptation of this stepwise 3D/2D/3D (SFEB floating / plating / isolated OV-like structures in suspension) protocol of differentiation demonstrated that human iPSC lines could efficiently generate retinal structures (Zhong et al., 2014) (Figure 3). First, initial SFEBs cultured with N2 supplement have been plated in matrigel-coated dishes, instead of laminin coating. Secondarily, they demonstrated that the presence of serum, taurine and boost of RA in specific time windows during the floating cultures allowed the formation of 3D retinal cups that seemed properly laminated, as shown by the presence after 180 days of culture of mature photoreceptors forming outer segment discs. This study demonstrated for the first time that these iPSC-derived photoreceptors could be functional, as evidenced by patch-clamp recordings showing that some of them were able to respond to light stimuli (Zhong et al., 2014). 
Over the same period, a couple of very interesting papers from the group of Y. Sasai reported the formation of a bi-layered optic cup using re-aggregated human ESCs (Kuwahara et al., 2015; Nakano et al., 2012) cultured as SFEB in presence of Matrigel and under high oxygen conditions (40\%). Using RAX-reporter ESC lines, they demonstrated that these conditions permitted to replicate the first step of retinal morphogenesis, with evagination of the RAXexpressing areas forming structures similar to optic placode, and followed by invagination of these structures leading to the generation of a bilayered optic cup-like structures, generally denoted as retinal organoids (Nakano et al., 2012). Like in the eye, the inner part of the invaginated epithelium differentiated to neural retina and the outer layer toward RPE lineage. In contrast to mouse ESCs, the presence of WNT inhibitor (IWR1e) was required to counterbalance the undesired effect of caudalization due to the high concentration (20\%) of knockout serum replacement (KSR) necessary for human ESC differentiation. Furthermore, the formation of optic cup structures was less frequent (10\% of SFEB) than in mouse ESC culture and efficient induction in human ESCs required the presence in a specific time window of serum and a smoothened agonist (SAG), that mimicked the effect of SHH (Nakano et al., 2012). In these conditions, photoreceptors can be identified within neural rosettes formed in the 3D structures by the expression of CRX (by day 35), Recoverin (by day 60) and NRL and Rhodopsin (by day 120). Using this 3D culture technique, the same group established new culture conditions, called "stepwise induction reversal method" that enabled the adjacent formation of RPE and neural retina (Kuwahara et al., 2015). SFEB cultured with 10\% KSR were primed (day 6 to 18 ) with low concentrations of BMP4, transferred in medium with N2 supplement and successively treated first with inhibitors of the FGF receptor and Glycogen synthase kinase 3 (day 18 to 24) and then (after day 24) with serum, RA and taurine (Kuwahara et al., 2015). This stepwise protocol in 3D permitted the self-formation of welllaminated neural retina but did not modify the rate and the yield of photoreceptor generation 
in comparison to their previous protocol (Nakano et al., 2012). A similar approach has been proposed by Wahlin and colleagues (Wahlin et al., 2017). These authors optimized the neural induction from SFEBs by replacing KSR with E6 supplemented with pro-neural supplement B27, as previously tested (Reichman et al., 2017), and cultured each single isolated OVstructure separately. Isolated 3D retinal structures became organized into laminated structures with photoreceptors localized at the outer side. Consistently with the work by Zhong and colleagues (Zhong et al., 2014), photoreceptors developed outer segment-like structures. As previously mentioned, moving toward future clinical applications requires the development of simple, robust and reliable retinal differentiation process, which also should reduce the need for exogenous factors (particularly Matrigel with variable composition) and serum. In this context, Reichman and colleagues recently developed a retinal differentiation protocol, which bypasses the step of EBs formation and subsequent plating on adherent substrates (Reichman et al., 2014). They demonstrated that leaving human iPSCs to overgrow in absence of the pluripotency factor FGF2 allowed the endogenous production of DKK1 and NOGGIN and that in presence of N2 supplement the overgrowing iPSCs could simultaneously generate RPE cells and self-forming neural retinal (NR)-like structures within 2 weeks. Early generated structures containing retinal progenitors presented an OV phenotype revealed by the co-expression of the transcription factors PAX6 and RAX, and an opposite gradient of VSX2 and MITF transcription factors between the neuroepithelium and the RPE (Reichman et al., 2014). Floating cultures of isolated NR-like structures allowed the differentiation of RPCs into all retinal cell types, in a sequential manner consistent with the in vivo vertebrate retinogenesis (Reichman et al., 2014; Reichman and Goureau, 2014). In terms of timing, the detection of photoreceptor precursors expressing CRX and Recoverin was observed between day 30 and 40 whereas mature photoreceptors, identified by the expression of Opsin or Rhodopsin, were obtained after 80 days of culture (Reichman et al., 2014). 
Successively, other protocols have been developed starting from human ESCs or iPSCs in adherent conditions (Figure 3). Wang and colleagues reported the generation of self-forming retinal spheres comprising photoreceptors expressing CRX only in presence of KSR and N2 supplement (Wang et al., 2015). Other authors proposed an exclusively 2D protocol, where $3 \mathrm{D}$ retinal tissue was generated and maintained on Matrigel, by using Neurobasal medium, N2 and B27 supplements, with addition of NOGGIN for neural induction, replaced after four weeks by DKK-1 and IGF-1 (Singh et al., 2015). The major drawback of this method is that the retinal tissue could not be cultivated for more than 10-12 weeks, which limits the possibility of retinal maturation (no marker for mature photoreceptor were reported). Also, the emergence of retinal tissues was reported to be not homogenous, requiring a purification of retinal cells for downstream applications.

With the aim of generating a homogenous population of photoreceptor precursors for transplantation, a four-step protocol has been recently reported (Barnea-Cramer et al., 2016). Adherent ESCs or iPSCs, cultured on Matrigel, were directly switched into retinal induction medium containing the same components already described for retinal induction starting from EBs (N2, B27 supplements, Insulin and NOGGIN). After the differentiation of PSCs into eye field-specified progenitors, in around 20 days, cells were collected to form neural spheres in suspension culture and then plated again on Matrigel to allow expansion and differentiation of RPCs. After four passages, corresponding to three months of culture, more than $90 \%$ of cultured cells were reported to stain positively for photoreceptor markers (CRX, NRL and NR2E3), with less than $10 \%$ of cells expressing the cell proliferation marker Ki67. Further differentiation of these cells in the presence of RA, Brain-derived neurotrophic factor, Ciliary neurotrophic factor (CNTF) and inhibitor of Notch pathway led to the generation of rod-like photoreceptors expressing Rhodopsin, Recoverin and Phosphodiesterase-6- $\alpha$ (PDE6 $\alpha$ ), but lacking outer segments. These results are surprising, especially because the activation of the 
CNTF pathway has been largely described as inhibiting the photoreceptor differentiation (Ozawa et al., 2004; Rhee et al., 2004; Rhee and Yang, 2010).

Based on a combination of the protocols reported by O. Goureau and V. Canto-Soler groups (Reichman et al., 2014; Zhong et al., 2014), the 2D/3D retinal differentiation protocol has been modified very recently by the group of R. Ali (Gonzalez-Cordero et al., 2017) (Figure 3). As described in (Reichman et al., 2017), confluent iPSCs were cultured in absence of FGF2 for the first two days to induce differentiation, and then switched into a N2supplemented medium to guide differentiation toward a neural cell fate. Self-forming neuroretinal vesicles as well as RPE appeared between weeks 4 and 7 of differentiation. Retinal differentiation medium consisted of the same elements reported by Zhong et al., with the difference that after the boost with RA between week 10 and 12, a small concentration of RA was maintained in the medium with the addition of N2 supplement. The protocol efficiently generated photoreceptors bearing nascent outer segments and developing presynaptic structures. Interestingly, the proportion of cone was quite high, corresponding to $17.8 \%$ of cells within the retinal organoid at 20 weeks of differentiation and including both $\mathrm{S}$ and L/M cones (Gonzalez-Cordero et al., 2017).

\subsection{Moving to future cell therapy products: Good Manufacturing Practices-compliant}

\section{protocols}

Important for future clinical applications are the continuous efforts to achieve Good Manufacturing Practices (GMP)-compliant protocols for all processes involved: cell line generation, differentiation, storage and distribution. Nowadays human iPSCs are routinely cultured in feeder-free conditions; nevertheless, adaptation of retinal differentiation protocols, largely relying on undefined compounds and xenogeneic molecules, should require some substantial adjustments. For example, the group of D. Lamba described the differentiation of 
both retinal and RPE cells from a GMP-compliant human iPSC-line, but still using Matrigel and Fetal Bovine Serum (Zhu et al., 2018). To date, a full adaptation to GMP conditions has been reported by Wiley and colleagues (Wiley et al., 2016) who have derived 35 human iPSC lines from adult fibroblasts of patients affected by different inherited retinal degenerations. Patient-specific iPSCs were differentiated to post-mitotic photoreceptor precursors by using a stepwise GMP-compliant 3D differentiation protocol, modified from (Nakano et al., 2012). They validated the generation of retinal organoids, following the replacement of xenogeneic components with GMP-grade human serum and human proteins of the extracellular matrix. Reichman et al. recently reported the adaptation of their previous retinal differentiation protocol of adherent iPSCs (Reichman et al., 2014) to feeder free and xeno-free conditions, demonstrating the ability of human iPSCs to generate self-forming retinal organoids in the presence of minimal and GMP-compatible raw materials (Reichman et al., 2017). Despite being GMP-compliant, the protocols for generation of photoreceptor precursors for cell transplantation require multiple time-consuming steps (EB formation and/or manual repicking) that should be tackled for an immediate adaptation to large scale-production. Additionally, the heterogeneity in production, composition and maturation of organoids represent an important problematic for the entire stem cell field, with differentiation and maturation efficiencies varying not only between iPSC lines and the protocol in use, but even between organoids originated at the same time and within different regions of a same organoid. Recent effort to better evaluate the current capabilities and limitations of the retinal organoid culture has been performed by the group of D. Gamm that set up a single differentiation protocol incorporating advances described by multiple laboratories in the production of retinal organoids from 16 human PSC lines (Capowski et al., 2019). By monitoring the appearance and structural organization of retinal organoids, this study pointed out the organoid technology as a powerful tool to produce photoreceptors for cell therapy. 
Nevertheless, automation of as many cell culture steps as possible, such as iPSC generation, maintenance and differentiation, is definitely needed to achieve manufacturing standards for the manufacturing of cell therapy products and overcome heterogeneity. Another major challenge for clinical application is the development of protocols for cryopreservation allowing an easy distribution of the therapeutic cell products. Even though the possibility to cryopreserve retinal organoids in GMP-compliant approaches without affecting the photoreceptors has been demonstrated (Reichman et al., 2017), it would be essential to establish conditions that allow for a reliable cryopreservation of the final cell product, as reported for iPSC-derived dopaminergic neurons (Nolbrant et al., 2017).

\subsection{Accelerating photoreceptor generation from human ESCs and iPSCs}

Regarding a transplantable cell population, i.e photoreceptors precursors, preliminary strategies have been deployed in order to accelerate their differentiation and increase their number. The Notch signaling pathway has been shown to inhibit photoreceptor production in developing retina (Jadhav, 2006). Accordingly, addition of DAPT, an inhibitor of the $\gamma$ secretase, was able to promote photoreceptor development in mouse ESCs using the SFEB system (Osakada et al., 2008). Blocking the Notch pathway during the retinal differentiation of human ESCs or iPSCs led also to an increase of photoreceptor precursors in the "3D retinal structures" generated using the previously described stepwise differentiation protocols (Kuwahara et al., 2015; Reichman et al., 2014; Tucker et al., 2013; Wahlin et al., 2017). Efficiently, the addition of an inhibitor of the $\gamma$-secretase at early stage of differentiation, when RPCs were still dividing, was sufficient to induce cell cycle exit for the large majority of progenitors, allowing the generation of about $40 \%$ of photoreceptor precursors expressing CRX, after only 35 days of culture (Reichman et al., 2014). While making possible the photoreceptor precursor enrichment within organoids, corresponding to the cell type desired 
for transplantation, these protocols do not allow to obtain a pure population of transplantable cells. The purification of ESC and iPSC-derived precursors of photoreceptors and the characterization of the developmental stage of these precursors represent a crucial point for future clinical applications. With retinal organoids recapitulating more and more faithfully human retinal differentiation, it has already been possible to test some candidate markers (see chapter 5.3).

\section{Transplantation of ESC and iPSC-derivatives for retinal repair}

\subsection{PSC-derived neural progenitors for retinal transplantation}

Historically, the first attempts of retinal neuron replacement using cells derived from PSCs concerned the delivery of neural progenitors into the vitreous or the subretinal space, where transplanted cells were expected to acquire a mature retinal identity by inductive signals operating in the retinal microenvironment. In 2006, Banin and colleagues reported the injection of 60,000 -100,000 neural progenitors derived from human ESCs into immunesuppressed rats (Banin et al., 2006). Presumed integration into the host retina was observed independently of the site of injection, but only a very low percentage of the engrafted cells $(<1.5 \%)$ expressed Rhodopsin, whereas $10 \%$ of cells were positive for the proliferative marker Ki67. Nevertheless, no tumor formation was detected by 16 weeks post-operation. Both intravitreal and subretinal transplanted neural progenitors also differentiated into glial and neuronal lineage, indicating a broad neural developmental potential as well as an insufficient competence for photoreceptor generation (Banin et al., 2006).

A similar kind of cell population (human ESC-derived neural progenitors) was transplanted in not immune-suppressed wild-type mice, in order to investigate the long-term survival together with the differentiation into the host retina (Hambright et al., 2012). The transplanted cells expressed specific markers of RPCs (RAX, SIX6, VSX2 and NEUROD1), but no markers of 
photoreceptor lineage such as CRX and NRL. Findings indicated that the survival of xenogeneic human grafts was better when the host RPE/choroid was not damaged, confirming that preservation of the blood-retinal barrier integrity well correlated with protection from immune-inflammatory responses and survival of the transplanted cells. Regarding cell maturation, at 3 months following transplantation, $67.5 \%$ of cells within the graft coexpressed Recoverin together with the human nuclear protein epitope, exclusively in the case of subretinal injection but not after intravitreal injection. No immunohistochemical assay for further photoreceptor maturation was reported.

The proof-of-concept that neural progenitors derived from both human ESCs and iPSCs could be effective in preserving vision has been reported by Wang and colleagues (Lu et al., 2013; Tsai et al., 2015) in Royal College of Surgeons (RCS) rats (classical rat model of RP). Subretinally transplanted human cells exerted a neuroprotective effect similar to the one observed after grafts of human fetal-derived neural progenitors (Cuenca et al., 2013; Gamm et al., 2007; Luo et al., 2014). Both human ESC- and iPSC-derived neural progenitors remained as phenotypically uncommitted progenitors following transplantation, since they continued to express Nestin but failed to express specific retinal markers. A small portion of the transplanted cell population was found to be immunoreactive for Ki67, but no tumor formation was observed in any of the studies. Visual function assays (optokinetic response, ERG and luminance threshold recording) showed that the vision loss was significantly slowed down in grafted eyes although not completely halted (Tsai et al., 2015). These findings are in agreement with histological results indicating that the transplanted neural progenitors preserved the endogenous photoreceptors, since the Outer Nuclear Layer (ONL) in the transplanted eyes was thicker than in the dystrophic control at all time points tested. The authors suggested that photoreceptor- and consequently vision preservation were mediated by the capacity of the injected neural progenitors to phagocyte photoreceptor outer segments. In 
support of this hypothesis, they found that human iPSC-derived neural progenitors expressed genes relevant for phagocytosis, and that they could phagocytose and degrade outer segments in vitro and in vivo, as supported by the detection of engulfed membranous discs detected within the cytoplasm of grafted neural progenitor cells. It seems that human iPSC-derived neural progenitors can compensate for dysfunctional phagocytosis in RCS rats, thus preserving visual function. Nevertheless, an additional paracrine effect of human neural progenitors through secretion of neurotrophic factors may also play an important role in retarding retinal degeneration in this rodent model (Luo et al., 2014).

\subsection{PSC-derived retinal cells for photoreceptor replacement}

The first transplants of human PSCs directed to a retinal fate was reported by the group of T. Reh (Lamba et al., 2009). Human ESCs were differentiated for 3 weeks accordingly to their "retinal determination" protocol (Lamba et al., 2006) in order to obtain a population composed of $80 \%$ retinal cells. Between 50,000 and 80,000 cells were transplanted without any prior selection and followed for up to 6 weeks, thanks to the labeling with Green Fluorescent protein (GFP)-expressing viruses before transplantation. In a first series of experiments aiming at evaluating the ability for integration and differentiation of the transplanted cells into a host retina, cells were injected either into the vitreous of new-born wild-type mice or into the subretinal space of adult wild-type mice. In both cases, the GFPpositive cells observed in the host ONL showed expression of rod and cone photoreceptor markers. The intravitreal injections resulted in a presence of GFP-positive cells not only in the ONL but also in the Inner Nuclear layer (INL) and the ganglion cell layer (Lamba et al., 2009). The connection of the presumptive human cells co-expressing GFP and photoreceptor markers to the host inner retinal circuitry was assessed by immunohistochemical analysis of synaptic markers, synaptophysin and post-synaptic density protein 95 (PSD95). In order to 
determine whether transplanted photoreceptors were functional, they performed xeno-graft experiments into $\mathrm{Crx}^{-/-}$mice, where photoreceptors failed to develop outer segments and ERG responses were non-recordable (Furukawa et al., 1997). After 2 to 3 weeks from the subretinal injection of human ESC-derived retinal cells, a partial restoration of light response was detected by ERG analysis compared to non-injected eyes (Lamba et al., 2009). The amplitude of the b-wave response correlated with the number of GFP-positive cells, with an average of 3000 cells per retina, although they did not bear any detectable outer segments. By using the same retinal differentiation protocol with human iPSCs, they also obtained photoreceptor-like cells and labeled them with a lentiviral vector driving the expression of the GFP under the control of the photoreceptor-specific promoter Inter-photoreceptor retinol binding protein (IRBP) (Lamba et al., 2010). After 8 weeks of differentiation, about $10 \%$ of cells within the total cell population expressed GFP, consistently with the two photoreceptor markers OTX2 and CRX (Lamba et al., 2010). Following Fluorescence activated cell sorting (FACS) and transplantation of 50,000 cells into the sub-retinal space of adult wild-type mice, only approximately 50 GFP-positive cells per eye were located into the ONL, as FACS was found to affect cell survival. Mature markers of photoreceptors, such as Rhodospin and Recoverin, were found to be co-expressed with GFP into the ONL, even if GFP-positive cells maintained a rounded morphology, with no outer segment formation (Lamba et al., 2010). With these studies, Lamba and colleagues (Lamba et al., 2010, 2009) concluded that human PSCs following differentiation to a retinal fate seemed able to integrate into the host retina and form functional photoreceptors, similarly to photoreceptor precursors isolated from a postnatal mouse retina (MacLaren et al., 2006).

As the time scale of retinal differentiation is much shorter in mice than in humans (weeks vs. months), a larger number of studies have been subsequently conducted by using differentiated mouse PSCs as source of cells for transplantation (Table 2). In 2011, Tucker and colleagues 
investigated the safety and the capacity of transplanted photoreceptors derived from a mouse reporter iPSC line to restore visual function. In brief, by exposing a mouse DsRed-iPSC line to differentiation medium containing Wnt and BMP pathway inhibitors, plus IGF and FGF-2, they obtained $33 \%$ of cells expressing Crx and $22 \%$ of cells expressing Recoverin by day 33 of differentiation (Tucker et al., 2011). However, approximately $30 \%$ of the cells were still undifferentiated, as showed by the expression of the pluripotency marker SSEA1, and transplantation of this heterogeneous population resulted in teratoma formation. In order to deplete the cell population of SSEA1-positive cell population, two consecutive rounds of Magnetic-activated cell sorting (MACS) were performed prior the sub-retinal injection into Rhodopsin ${ }^{-/}$mice. DsRed-positive cells within the host ONL have been described as expressing Retinal Outer Segment Membrane Protein 1 (ROM1) and several synaptic markers. The ERG analysis of transplanted eyes showed an increase in b-wave amplitude (Tucker et al., 2011), demonstrating for the first time that transplantation of iPSC-derived photoreceptors could mediate vision improvement. In another study, Homma and colleagues also investigated the in vivo functionality of mouse iPSC-derived photoreceptors after transplantation. To easily identify differentiating photoreceptor precursors, they used an iPSC line generated from transgenic Nrlp.EGFP mouse fibroblasts. GFP-positive cells isolated by FACS were transplanted into a wild type adult mouse retina. The calcium responses measured in grafted iPSC-derived rods 2 weeks after transplantation were comparable to those measured in native adult mouse rods, suggesting similar functionality (Homma et al., 2013). With the publication by Eiraku and colleagues of a protocol recapitulating major steps of eye and retinal development (Eiraku et al., 2011), the retinal differentiation in 2D was abandoned in favor of an organoid-like approach using mouse ESCs. Different groups have investigated the capability of photoreceptor precursors derived from 3D mouse ESC cultures to integrate into adult host retina and to mature into new photoreceptors (Table 2). Two early studies have 
focused on the identification of in vitro ontogenetic equivalent of well-characterized in vivo postnatal photoreceptor precursors (Decembrini et al., 2014; Gonzalez-Cordero et al., 2013). By using an adeno-associated viral (AAV) vector carrying GFP under the control of a Rhodopsin promoter (AVV2/9.Rhop.GFP), Gonzalez-Cordero and colleagues focused their study on rod precursors. They analyzed and compared gene expression profiles of Rhop.GFPpositive cells from mouse P12 rods, and from 26- or 34-day-old retinal organoids derived from mouse ESC line. Rhop.GFP-positive cells from 26-day-old organoids were selected for transplantation studies in Gnat $1^{-/-}$mice, as Rhop.GFP-positive cells closely resembled to P12 rods. Identification of presumptive integrated cells was based on acquisition of a mature phenotype and co-expression of G Protein Subunit Alpha Transducin 1 (Gnat1) and GFP, which was found only in $0.3 \%$ out of 200,000 injected cells (Gonzalez-Cordero et al., 2013). The number of GFP-positive cells in the ONL was consistently lower compared to the one obtained by transplanting primary mouse photoreceptor precursors. Possibly, the choice of P12 rods as primary cells of reference, as well as the choice of Rhodopsin promoter (instead of $\mathrm{Nrl}$ ) to label the cells of interest may have led to the selection of more mature rods derived from mouse ESCs, and not immature rod precursors. Transplantation into two additional mouse photoreceptor-degenerative models $\left(R h o^{-/-}\right.$and $\left.\operatorname{Prph} 2^{r d 2 / r d 2}\right)$ resulted in a lower number of GFP-positive cells in the ONL than in Gnat $1^{-/-}$mice, in agreement with previous work showing that the type or the stage of the disease has a major impact on the outcome of primary photoreceptor precursor transplantation (Barber et al., 2013). Similar percentage of fluorescent cells detected within the host ONL of wild type immunodeficient mice, close to $0.4 \%$, was reported in another study using photoreceptors from mouse ESC-derived retinal organoids (Decembrini et al., 2014). Importantly, the use of a transgenic mouse ESC line expressing GFP under the control of Crx promoter minimized the risk of false positive results deriving from the transduction of viral particles. This reporter cell line also allowed to follow 
developing photoreceptors in optic cup-like structures and to purify GFP-positive differentiating photoreceptors by FACS (Decembrini et al., 2014).

The abovementioned studies from different groups were interpreted at that time as a demonstration of the competence of photoreceptors derived from mouse ESCs and iPSCs (2D and $3 \mathrm{D}$ differentiation protocols), to integrate (though in very small numbers) into a host retina and drive a partial restoration of visual function.

\subsection{Change of perspective on donor photoreceptor integration}

\subsubsection{Demonstration of cytoplasmic material exchange following transplantation}

The evaluation of donor photoreceptor contribution to host retinal repair in animal models has relied on the presence of donor cells labeled with fluorescent reporters, with the assumption that the fluorescent-positive cells corresponded to the injected cells. This strategy led to the conclusion that donor photoreceptor precursors transplanted into the subretinal space of different blind mice models can physically integrate into the degenerating retina, differentiate into mature photoreceptors, form synaptic connections and possibly lead to recovery of visual function (Barber et al., 2013; MacLaren et al., 2006; Pearson et al., 2012). Over the last two years, the interpretation of these results has been reconsidered after the publication of several studies showing that fluorescent-positive photoreceptors are almost exclusively endogenous host photoreceptors resulting from a cytoplasmic material exchange between donor and host cells (Decembrini et al., 2017; Ortin-Martinez et al., 2017; Pearson et al., 2016; SantosFerreira et al., 2016a; Singh et al., 2016). According to these new findings, it appears that transplanted photoreceptors do not migrate and integrate within the host ONL, instead, most probably they stay in the subretinal space. Material exchange has been demonstrated to be bidirectional, meaning that host photoreceptors can transfer cytoplasmic compounds to the transplanted cells in the subretinal space (Ortin-Martinez et al., 2017; Pearson et al., 2016; 
Santos-Ferreira et al., 2016a; Singh et al., 2016). The mechanisms of this process are yet not clearly understood; it does not seem to involve nuclear fusion or uptake of free-floating proteins (Nickerson et al., 2018; Santos-Ferreira et al., 2017). Furthermore, whether material exchange could span synaptic connections and extend to host cells within the INL is still questioned. The presence of a low GFP signal beyond the ONL, in bipolar and Müller glial cells, has been reported. These observations were restricted to mouse $\mathrm{Nrl}^{-/-}$recipients following Nrl:EGFP donor cell transplantation (Ortin-Martinez et al., 2017) and need to be corroborated by further studies in different models. In addition to being donor cell-stage dependent, the extent of the phenomenon also correlates with the host retina cytoarchitecture; specifically, the integrity of the outer limiting membrane (OLM) could play a controversial role in enhancing (Waldron et al., 2018) or impeding (Ortin-Martinez et al., 2017) the material transfer. Indeed, it is still debated whether breaks in the OLM could facilitate the cell-cell contact or cytoplasmic material transfer via noncontact-mediated mechanisms, or could actually facilitate the cell integration within the host ONL.

\subsubsection{Cytoplasmic material exchange with mouse PSC-derived photoreceptors}

According to recent studies, not only mouse post-natal photoreceptor precursors but also mouse ESCs-derived photoreceptors can engage into cytoplasmic material exchange (Kruczek et al., 2017; Pearson et al., 2016; Waldron et al., 2018). In particular, these authors sought to determine whether mouse ESC-derived and primary donor-derived cones could truly integrate in different mouse models of retinal degeneration. Results from previous studies that used mouse primary cone precursors or cone-rod intermediates "cods" from $\mathrm{Nrl}^{-/}$retinas (Decembrini et al., 2017; Santos-Ferreira et al., 2015; Smiley et al., 2016) and failed to produce cells exhibiting cone morphologies, had contributed to the raise of questions about the nature of integrated cells. Transplantation of cones in rod-dominant recipients is particularly suitable to investigate donor-host material exchange, as cone nuclei bear multiple 
chromocenters and are bigger than rod nuclei, providing an additional contrast between donor and host cells. Results from Waldron and colleagues (Waldron et al., 2018) confirmed that, regardless of their origin, mouse ESC-derived cones, donor-derived cones and cone-like cells underwent cytoplasmic material transfer with rods and accounted for the majority of GFPpositive cells found in wildtype or degenerative retinas of the recipients. As expected, the recipient retinal environment impacted the transplantation outcome, with the highest number of transplanted cells counted when $\mathrm{Nrl}^{-/-}$and $\operatorname{Prph}^{r d 2 / r d 2}$ mouse models were used as host retina. These dystrophic retinas, in which the integrity of the OLM was disrupted, supported an increased number of integrated donor cone photoreceptors, compared to wildtype recipients, in addition to cytoplasmic material transfer events. These results suggested that the relative contributions of material transfer and donor cell integration to the transplantation outcomes could depend on the disease etiology and the host retinal environment. To avoid material transfer events between donor and host photoreceptors, Kruczek and colleagues (Kruczek et al., 2017) transplanted mouse ESC-derived cones into Aipl1/- mice, a model of end-stage LCA characterized by rapid and extensive photoreceptor loss (Ramamurthy et al., 2004). Starting from the protocol previously established by the group (Gonzalez-Cordero et al., 2013), the generation of cones within retinal organoids was increased by adding a short RA pulse and the mouse ESC-derived cones were isolated by viral labeling using a AAV2/9 vector encoding the GFP under the control of a fragment of the human L/M Opsin promoter. Analysis of GFP-positive cells 3 weeks after transplantation demonstrated that despite lacking morphological features of mature photoreceptors, expression of phototransduction-related and synaptic markers was detected within the transplanted cells clustered in close proximity to the host INL (Kruczek et al., 2017). Although further studies assessing functionality of the transplanted cells are required, these 
results showed for the first time that purified mouse ESC-derived cones can survive in a degenerated retinal environment.

\subsubsection{Identification of human cells following retinal xeno-transplantations}

Most of the studies so far have been conducted in mouse-to-mouse conditions. Regarding xenotransplantation of human photoreceptors into rodent host retina (Table 3), the number of studies specifically addressing cytoplasmic material transfer from human donor cells to mouse host cells are still limited and appropriate multiple controls are required. The presence of species-specific antigens and the nuclear cytological heterogeneity have already proved to be a valuable tools to distinguish, for example, human photoreceptors from mouse or rat photoreceptors (Gagliardi et al., 2018; Nickerson et al., 2018). Nevertheless, immunostaining of cytoplasmic components, useful for morphological interpretation, should always be employed in combination with nuclear labeling through human probes for fluorescent in situ hybridization to identify material exchange events (Figure 4). Antibodies targeting human nuclear antigens could also be used, but it should be taken in consideration that nucleartargeted proteins, such as Cre-recombinase, can also be exchanged (Nickerson et al., 2018; Pearson et al., 2016; Santos-Ferreira et al., 2016a). To our knowledge, the exchange of speciespecific nuclear antigens has never been reported so far. As it seems unlikely that human cells would have the capacity to adopt the size and the nuclear features of mouse photoreceptors (MacLaren, 2017), the identical morphology exhibited by labeled donor cells and host photoreceptors observed in some xenograft approaches (Lamba et al., 2009; Zhu et al., 2017) might be explained by the exchange of cell material rather than integration of donor cells, in the absence of further staining to confirm human nuclei identity. For instance, as shown in Figure 4, human cells can be easily distinguished from host rat retinal cells after subretinal transplantation in a photoreceptor degenerative model, the Rhodopsin $\mathrm{P} 23 \mathrm{H}$ transgenic rat (LaVail et al., 2018). Human retinal cells could be identified by specific antibodies against 
human antigens, by the specific morphology of their nuclei and by Fluorescence in situ hybridization (FISH) using probes targeting species-specific chromosome (human Y chromosome) combined with immunostaining for the cytoplasmic human marker STEM121 (Figure 4).

\subsubsection{Cytoplasmic material exchange with human PSC-derived photoreceptors}

Similar to experiments with mouse ESC-derived photoreceptors, subsequent transplantation studies with human PSC-derived retinal cells have been performed preferentially in hosts with no remaining ONL in order to reduce the possibility of labeling artifacts due to cytoplasmic material exchanges (Table 3). A study from Barnea-Cramer and colleagues described transplantation of human ESC- and iPSC-derived retinal cells (Barnea-Cramer et al., 2016) into $r d 1$ mice, a widely used model of end-stage RP. As this protocol was supposed to result into generation of a homogenous population of photoreceptor progenitors expressing CRX, NRL and NR2E3, retinal cells were directly transduced with AAV driving the GFP expression by the photoreceptor-specific rhodopsin-kinase promoter, without any preliminary selection prior to the eye implantation. Subretinal transplantation into fully degenerated $r d 1$ mice showed survival of GFP-positive cells three weeks after transplantation in mice treated with cyclosporine to prevent immune rejection, with transplanted human cells forming a distinct layer in the subretinal space and expressing phototransduction-related markers (Barnea-Cramer et al., 2016). The authors also showed that undifferentiated retinal progenitors did not survive following transplantation, confirming the importance of the developmental stage for donor cells. Recovery of visual response evaluated by both optomotor test and light avoidance assay was observed and correlated with the number of surviving donor cells (Barnea-Cramer et al., 2016).

All the studies described so far used unsorted human PSC-derived retinal cells differentiated with 2D culture systems. In 2017, Gonzalez-Cordero and colleagues reported for the first time 
the transplantation of human cones isolated from retinal organoids. The development of a new differentiation system, as we have previously detailed in paragraph 4.1, allowed for the generation of 3D retinal structures sufficiently enriched in cones to support efficient isolation by FACS of virally labeled L/M cones expressing GFP (Gonzalez-Cordero et al., 2017).

Transplantations were performed in two mouse models, the $\mathrm{Nrl}^{-/}$mouse, in which the ONL is preserved, and the Aipl1 ${ }^{-/}$mouse, lacking ONL. Donor human cells were identified in three ways: using antibodies against human markers comparing the size of nuclei of GFP-positive and host photoreceptors, and by performing FISH for mouse Y chromosome and transplanting sex-mismatched human cells. Evidence from these experiments allowed to confirm the human identity of the majority of GFP-positive cells, predominantly located within the subretinal space. In $\mathrm{Nrl}^{-/}$recipients, a small number of human GFP-positive cells, positively stained with Human Nuclear Antigen (HNA) and displaying significantly larger cell bodies and nuclei than the surrounding host photoreceptors, were incorporated into the host ONL cells. A minority of GFP-positive cells localized within the ONL was positive for mouse Y chromosome but negative for HNA staining, and bore morphologies and nuclear sizes typical of murine photoreceptors, indicating that human photoreceptors could also be engaged in material exchange with mouse photoreceptors. However, material transfer does not seem to be the prevalent phenomenon accounting for the presence of human GFP-positive cones in $\mathrm{Nrl}^{-/-}$ mice, contrary to what has been shown for mouse ESC-derived cones (Waldron et al., 2018). Nevertheless, none of the two mechanisms should be excluded when assessing transplantation outcomes in future experiments with human PSC-derived retinal cells. When transplanted in the end-stage degeneration model (Aipl1 ${ }^{-/}$mouse), human PSC-derived cones formed a distinct layer adjacent to the host INL, in close proximity to the terminals of host PKC $\alpha$ expressing bipolar cells, but they did not develop outer segments (Gonzalez-Cordero et al., 2017). 


\subsection{Isolation and transplantation of photoreceptors derived from PSCs}

4.4.1 Selection of mouse photoreceptor precursors by targeting different cell surface antigens The whole of the studies discussed so far showed an increasing attention toward the necessity of selecting photoreceptor precursors before transplantation. With the exception of the study by Tucker and colleagues (Tucker et al., 2011), which as described above adopted a negative selection approach, the majority of the works was based on a positive selection of the population of interest (Decembrini et al., 2014; Gonzalez-Cordero et al., 2013; Lamba et al., 2010). These studies have focused on characterization of the developmental stage of ESC and iPSC-derived photoreceptors corresponding to P4 photoreceptor precursors (MacLaren et al., 2006; Pearson et al., 2012). For this purpose, reporter cell lines have been used, enabling the identification of photoreceptors via the expression of a fluorescent protein under the control of a photoreceptor-specific promoter or knock-in in a photoreceptor-specific locus. However, as genetically or virally labeled cells are not suitable for clinical applications, several studies have been focusing on the identification of cell surface markers characterizing photoreceptor precursors for future isolation (Figure 5). In this context, the plasma membrane protein Cluster of Differentiation 73 (CD73), also known as ecto-5'-nucleotidase, has been reported to be specifically expressed in the developing photoreceptors of mouse retina (Koso et al., 2009), and was concomitantly indicated as an effective surface antigen for the selection of transplantation competent photoreceptor precursors from early postnatal mouse retina (Eberle et al., 2011; Lakowski et al., 2011). Selection based on CD73 was equally effective with FACS and MACS approaches, leading to a significant enrichment of photoreceptor precursor population with both methods. Lakowski and colleagues performed photoreceptor precursor isolation also by using CD73 in combination with another cell surface marker, CD24 (Lakowski et al., 2011). Contrary to CD73, CD24 is expressed in the embryonic retina and is 
down regulated shortly after birth in mouse. Therefore, a combined selection for doublepositive CD73/CD24 cells should allow for exclusive purification of photoreceptor precursors, by excluding mature photoreceptor cells which maintain CD73 but not CD24 expression. Nevertheless, the CD73-positive and the CD73/CD24-double positive populations integrated with the same efficiency (Lakowski et al., 2011). As CD73 expression was maintained in mature photoreceptors, an additional combination of four CD markers, CD73, CD24, CD133 and CD47, has been proposed in order to select exclusively the cell corresponding to post-mitotic precursors in mouse ESC-derived retinal organoids (Lakowski et al., 2015). CD73 and CD133 were found to be highly expressed in Nrl-expressing rod precursors, conferring thus the rod lineage specificity, while CD47 and CD24 expressed in young post-mitotic cells confer specificity for the appropriate ontogenetic stage. At Day (D) 27 , identified as developmental stage to obtain transplantation-competent cells, the four CD markers were co-expressed in $25 \%$ of cells in mouse ESC-derived retinal organoids. The authors also identified a marker for the negative selection of potentially harmful mitotically active cells, CD15, therefore proposing a combination of positive and negative approaches as photoreceptor precursor purification strategy. Following transplantation into the subretinal space of either wild-type or Gnat1 $^{-/-}$mice of 200,000 cells isolated by FACS, some cells were detected into the recipient retina bearing typical rod morphology, probably resulting from donor-host material exchange (Lakowski et al., 2015).

Contrary to these combined strategies, Santos-Ferreira and colleagues demonstrated that the targeting of a single cell surface antigen, CD73, was sufficient to efficiently enrich a homogenous population of rod precursors from mouse ESC-derived organoids (SantosFerreira et al., 2016b). At D26, cells expressing CD73 corresponded to $60 \%$ of the total cell population from dissociated organoids, consistent with the percentage of CD73-positive cells measured in P4 mouse retina (Eberle et al., 2011). MACS selection allowed an enrichment of 
85\% of CD73-positive cells. When CD73-sorted cells were transplanted into a mouse model of severe photoreceptor degeneration $\left(C p f l 1 / R h o^{-/}\right)$, they survived in the subretinal space and expressed rod-specific markers but did not acquire a mature photoreceptor morphology; in addition, the expression of synaptic markers was reduced and the ERG recording failed to show functional improvements in the transplanted eyes (Santos-Ferreira et al., 2016b).

\subsubsection{Specific photoreceptor cell surface antigens to isolate transplantable human} photoreceptor precursors

In a human context, CD73 has been reported to be specifically expressed in CRX/Recoverindouble positive photoreceptor precursors derived from human iPSCs (Reichman et al., 2017, 2014), as confirmed recently in fetal and adult human retinas in vivo (Lakowski et al., 2018, 2015). The combination of positive and negative selection based on the specific expression of a panel of cell surface antigens (CD73, CD24, CD133, CD47 and CD15) described in mouse (Lakowski et al., 2015) was not suitable for selection of human photoreceptor precursors, as only CD73 and CD133 were identified in a screening for cell surface biomarkers expressed in human adult and fetal retinas (Lakowski et al., 2018). The approach consequently proposed by these authors to isolate photoreceptor precursors from human PSC-derived organoids consisted in a preliminary double negative selection against CD29 and SSEA-1, before proceeding with a positive selection targeting CD73. However, both the efficiency and the yield of cells following such triple selection by FACS seem still too low to satisfy the potential demand in clinical cell therapy. Surprisingly, targeting CD73 allowed a photoreceptor enrichment from old fetal retinal tissue, but not from old retinal organoids derived from human iPSCs (Lakowski et al., 2018).

The specificity of CD73 expression for a given subtype of human photoreceptors, rods or cones, is still debated. A recent study focalized on cone transcriptome during human development, with the intent of comparing fetal and PSC-derived cones (Welby et al., 2017). 
Cones in both human retinal explants and organoids were labeled for sorting by using AAV2/9 vector encoding the GFP under the control of a fragment of the human L/M Opsin promoter. Having defined the transcriptomic signature of human fetal L/M opsin cones at different stages of fetal development, they first demonstrated that PSC-derived cones shared a similar gene expression signature. They then used these data in attempt to identify cell surface markers whose expression was upregulated in GFP-positive fetal cones to further isolate cones from both human retinal explants and organoids. Interestingly, the CD73 expression was not found upregulated in their dataset and no single cell surface markers were exclusively expressed in the GFP-positive cell population. A combination of different markers, CD26, CD147 and CD133, was proposed to isolate human cones from human ESC-derived retinal organoids, but the enrichment achieved $(30 \pm 16 \%)$ requires further optimization (Welby et al., 2017). To this purpose, the use of a more specific construction to identify cones should lead to a refined analysis. For example, the vector AAV2-7m8 in conjunction with the short human Opsin promoter PR1.7 has been described as an ideal combination to target foveal cones in non-human primates (NHPs) (Khabou et al., 2018).

Unlike these results, Reichman and colleagues demonstrated the co-expression of CD73 with cone markers by immunofluorescence analysis on sections of human iPSC-derived retinal organoid (Reichman et al., 2017). These results were subsequently confirmed by gene expression analysis on isolated CD73-positive cells (Gagliardi et al., 2018), indicating that CD73 is a marker for both human rods and cones. Targeting of CD73 by MACS in dissociated cells from retinal organoids between 100 and 130 days of differentiation allowed the separation of a significantly enriched population of photoreceptor precursors that could be used for transplantation studies in immunodeficient rats or in a rat model of photoreceptor degeneration. Authors further confirmed the identity of CD73-positive cells as photoreceptors by performing CD73-based MACS on retinal organoids derived from a fluorescent Crx 
human iPSC reporter line generated by targeting the adeno-associated virus integration site 1 (AAVS1) locus with CRISPR/Cas9 strategy (Gagliardi et al., 2018). Targeting of CD73 has also been successfully used to sort photoreceptors from human iPSC-derived neural retina (Lidgerwood et al., 2018). With the advancements in RNA-sequencing (RNA-Seq), even to a single cell level, different studies have started looking deeper to compare the transcriptome dynamics of developing photoreceptors during human development in vivo and in vitro, within 3D retinal structures derived from human PSCs. Kaewkhaw and colleagues correlated for the first time immunohistochemistry data with photoreceptor transcriptomic profile obtained by RNA-Seq using a human ESC reporter line carrying in the AAVS1 locus the GFP under the control of Crx promoter (Kaewkhaw et al., 2015). Unfortunately, since the analysis was focused on early developmental stages of photoreceptors $(37,47,67$ and 90 days of differentiation), before the onset of Opsin and Rhodopsin expression, it was unable to provide a full characterization of gene expression profiles during rod and cone maturation. Different proteins were proposed as candidate cell surface markers for human photoreceptors, such as Sodium-dependent neutral amino acid transporter SLC6A17, Solute carrier family 40 member 1 and Potassium voltage-gated channel $\mathrm{KCNH} 2$. Another Potassium voltage-gated channel, KCNV2, was also identified as a candidate marker for human photoreceptors, as previously suggested for mouse photoreceptors (Postel et al., 2013). No direct comparison with global gene expression profile of human photoreceptors during embryonic development was performed in this study. As previously mentioned (chapter 3), further data from transcriptomic analysis, such as single cell RNA-Seq, will be of great utility not only to discover new potential markers of photoreceptors but also to precisely characterize the ontogenic stage of retinal organoids and to facilitate the acquisition of human PSC-derived cells equivalent to fetal retinal cells. 


\subsection{Transplantation of PSC-derived retinal sheets}

\subsubsection{Transplantation of mouse PSC-derived retinal sheets}

As mentioned above, several retinal differentiation protocols allowed for the generation of photoreceptor precursors organized in a pseudo ONL within 3D organoids (Gonzalez-Cordero et al., 2017; Nakano et al., 2012; Reichman et al., 2014; Zhong et al., 2014), providing opportunity for grafting retinal sheets derived from PSCs (Table 3; Figure 5); a previously explored approach that used for donor grafts either fetal retinal or fetal photoreceptor sheets (Seiler and Aramant, 2012).

In a proof-of-concept study, the group of $\mathrm{M}$. Takahashi reported the first transplantation using mouse ESC- and iPSC-derived 3D retinal sheets (Assawachananont et al., 2014). As retinal sheet transplantation has been suggested to be more effective in advanced stages of retinal degeneration when the ONL is completely gone (Seiler and Aramant, 2012), the $r d 1$ mouse model was suitable to recapitulate the clinical scenario of end-stage retinal degeneration, with complete loss of rods occurring by 3 weeks of age (Lolley et al., 1994). Retinal sheets were prepared at different stages from optic cup-like structures generated from both Rx-GFP knock-in ESC line and Nrl-GFP knock-in iPSC line that could be identically differentiated toward retinal and photoreceptor lineage (Assawachananont et al., 2014). Grafts of retinal derivatives between D11 and 17 of differentiation were found to have the best competence to form structured ONL containing photoreceptors with different degrees of inner and outer segment formation. "Older grafts", between D18 and D24, showed the tendency to become disorganized and integration occurred with individual cells, similarly to cell suspension transplantation. The integration pattern of the grafts was mainly associated with their subsequent structural integrity. Indeed, the presence of an INL-like layer in the grafts can interfere and prevent direct contact between graft photoreceptors and host INL. In grafted sheets presenting an incomplete INL, graft ONL formed rosette-like structures and were able 
to make a direct contact with host bipolar cells. However, these rosettes often had INL-like layer surrounding the ONL, blocking the contact with host RPE on the other side (Assawachananont et al., 2014). Aiming at visualizing a direct host-graft synaptic contact, the same group generated a specific mouse reporter iPSC line to derive retinal sheets that express CtBP2-tdTomato at photoreceptor synaptic terminals (Nrl-GFP/ROSA::Nrl-CtBP2-tdTomato) after differentiation (Mandai et al., 2017a). To identify rod bipolar cells, the authors generated L7-GFP/rd1 mice, by crossing $r d 1$ mice with L7-GFP mice that express GFP in rod bipolar cells. Transplanted grafts of Nrl-GFP/ROSA::Nrl-CtBP2-tdTomato retinal sheets cut out from D13 OV-like structures could mature and establish synaptic connections into L7-GFP/rdI mice after three weeks. Ex vivo multielectrode array (MEA) recordings demonstrated that light-responsive signals were transmitted to bipolar cells and then to host RGCs in the grafted area, although the measured amplitudes were smaller than those of wild-type retina and displayed more variable patterns. The optokinetic test failed to show a visual improvement in transplanted animals over dystrophic controls, while light-responsive behavior, analyzed through an adaptation of a shuttle-avoidance system in mice pre-selected to have substantial amount of subretinal grafts, were detected in around half of the tested animals (Mandai et al., 2017a). This proof-of-concept study showed that iPSC-derived retinal sheets can developed a mature ONL when transplanted into the subretinal space of end-stage retinal-degeneration mice and can respond to light.

\subsubsection{Transplantation of human PSC-derived retinal sheets}

Human ESC and iPSC-derived retinal sheets have also been demonstrated to survive and mature following transplantation in a degenerated retinal environment in different animal models (Iraha et al., 2018; McLelland et al., 2018; Shirai et al., 2016; Tu et al., 2019). In a context of xenografts, the development of immunodeficient retinal dystrophic rodents as recipient models has allowed to monitor the long-term transplant growth and survival. In a 
first study, retinal sheets derived from two human ESC reporter lines (RX::Venus and CRX::Venus) at different stages of differentiation were transplanted in immunodeficient NUDE rats or in immunodeficient retinal degenerated rho S334ter-3 NUDE rats (Shirai et al., 2016). The majority of the grafts observed at D240-270 developed ONL in rosette-like structures, where the development of inner segment/outer segment structures can be observed, and the regular presence of human INL cells in the graft prevented the direct contact of human photoreceptors with host bipolar cells (Shirai et al., 2016). Very recently, similar immunodeficient retinal dystrophic rats have been used to evaluate the potential of human ESC-derived retinal sheets to restore the visual function up to 10 months post-surgery (McLelland et al., 2018). Based on the differentiation protocol adapted from Zhong and colleagues (Zhong et al., 2014), retinal sheets were prepared from retinal organoids between D30 and 65 of differentiation, when no mature photoreceptors should be present. The transplanted sheets differentiated into functional photoreceptors, leading to visual improvements as evaluated by the optokinetic testing and the electrophysiologic recording in the superior colliculus at 2 to 4 months after transplantation. Interestingly, up to 7 months after transplantation, when no active host photoreceptors were supposed to remain, 9 of 13 rats showed responses to flashes of light in the superior colliculus, with no responses detected in the controls (McLelland et al., 2018).

With the same purpose, to monitor the xenograft maturation for extended time, Iraha and colleagues (Iraha et al., 2018) established a new mouse model with a complete degeneration of ONL by crossing $r d 1$ mouse with immune-compromised $I L 2 R g^{\text {null }}$ (NOG) mouse. As in the previous study (Shirai et al., 2016), retinal sheets around D60 derived from a human transgenic CRX::Venus ESC line were used for transplantation; immunohistological analysis performed 4 months later confirmed long-term survival and maturation of the grafted photoreceptor layer, without rejection or tumorigenesis (Iraha et al., 2018). While full-field 
ERG responses were not successful, the authors reported light responses from the host RGCs by MEA directly in the grafted area from 3 out of 8 transplanted retinas. Interestingly, mouse retinas with human ESC-derived grafts showed a lower responsiveness compared to mouse iPSC-derived transplants, highlighting how the use of allografts versus xenografts can have an impact that should be considered in the evaluation of the transplantation outcome.

Based on these background data, transplantation of human ESC-derived retinal tissues was then performed into two new monkey models of retinal degeneration (Shirai et al., 2016; Tu et al., 2019). In these models, a large perimacular area of the ONL was selectively targeted for damage either by subretinal injection of cobalt chloride solution or by 577-nm optically pumped semiconductor laser photocoagulation. Given their immature developmental stage, retinal tissues at the moment of transplantation were enriched in proliferating progenitors, potentially dangerous in a clinical context. Even though very few animals (one eye of the laser-induced model and three eyes of the cobalt-induced model) were transplanted, no tumor formation was observed, and at the time of graft histological analysis, around 140 days after transplantation, a few proliferative cells were still present (Shirai et al., 2016). Similar to experiments in rats, cells within the grafts gave rise to different cell types, including rod and cones but also bipolar cells expressing PKC $\alpha$. Immunohistochemical analysis suggested the formation of host-graft synaptic connections but no functional recovery was detected by focal ERG, maybe due to the small size of the graft (Shirai et al., 2016; Tu et al., 2019). Even though the authors transplanted only two monkeys, they were able to observe a mild recovery of visually guided saccade in one animal 1.5 year after transplantation (Tu et al., 2019). These studies showed that, as with human primary fetal sheet, human ESC-derived retinal tissues have a relatively good capacity to grow, differentiate and maturate in a retinal environment mimicking human retinal dystrophies, with promising potential for vision 
restoration. They also pointed out the importance of using immunodeficient models for testing cell replacement therapies with retinal derivatives from human PSCs.

\subsection{Toward long-term survival: the role of immune response following photoreceptor transplantation}

To date, much of the work reported for cell transplantation using ESC or iPSC-derived photoreceptors have been accomplished with mouse donor cells in mouse models. Regarding retinal derivatives of human ESCs or iPSCs immune responses and subsequent rejection of transplanted cells remains an important challenge. With transplantation surgery potentially damaging the blood-retina barrier, the subretinal microenvironment could lose its immunopriviledged because immune cells may enter the retina and favor grafted cell rejection. A more comprehensive understanding of the host immunological responses after human iPSC-derived photoreceptor transplantation is needed. Unfortunately, in the works published so far modulation of the host immune system is not a consistent factor, varying from use of immune-compromised recipients, use of immunosuppressive drugs and no immunosuppression at all. The necessity to use immunosuppressed recipients to achieve a long-term cell survival has been demonstrated (Zhu et al., 2017) and in addition to adaptive immune system, innate immune system has been shown to play a role following photoreceptor transplantation in mouse (Neves et al., 2016). The expression of mesencephalic astrocyte-derived neurotrophic factor (MANF) in CD11b-positive innate immune cells can promote retinal repair after injury and when MANF was supplemented to donor mouse photoreceptors, the number of grafted cells in the recipient retina increased (Neves et al., 2016). Nevertheless, it is still unclear how to regulate this mechanism. The use of immunecompromised photoreceptor degenerative models in the case of xenografts is becoming more common (Iraha et al., 2018; McLelland et al., 2018; Shirai et al., 2016). This strategy seems 
more reliable when long-term immunosuppression is needed compared to immunosuppressive drugs and should avoid the severe side effects caused by long-term immunosuppressive treatment.

Another open question concerning the use of human iPSC for cell therapy is whether xenograft models are truly predictive of transplantation efficacy for allografts in humans. In order to test the relevance of matching MHC-haplotypes of donors and recipients, NHPs could be useful as an alternative to classical xenograft experiments by employing specific photoreceptors derived from homozygous Mafa haplotyped macaque iPSCs, as previously developed for RPE cell transplantation (Sugita et al., 2016). Currently, the major scientific limitation to research with NHPs is the lack of reproducible models of photoreceptor degeneration, even though preliminary results have been reported on a very restricted number of animals (Chao et al., 2017; Shirai et al., 2016). Nevertheless, transplantation in larger animals displaying close-to-human visual anatomy and function, especially in NHPs because their retinas present a fovea (the specific targeted region of photoreceptor cell therapy) is required for a better understanding of the mechanisms governing the integration, differentiation and survival of photoreceptor precursors following transplantation into the retina.

Since use of human PSC derivatives is limited by the rejection of transplanted cells due to differences in their human leukocyte antigen (HLA) genes, the possibility to create a bank of iPSC lines providing adequately HLA-matched iPSC line should limit immune cell response. Preliminary studies highlighted the feasibility of a haplobank approach by selecting HLA homozygous donors (Gourraud et al., 2012; Taylor et al., 2012), but one major challenge is to ensure that the stocked iPSCs can actually cover a wide population. Simulations of the estimated number of homozygous HLA lines required to provide HLA-B, HLA-B and HLADR compatible cells in various populations have shown that a relatively low number (50 to 
150) of selected donors could match for 50 to $90 \%$ of the respective populations (Gourraud et al., 2012; Taylor et al., 2012). The development of a global iPSC library within an international network is under consideration (Turner et al., 2013).

\section{Futures directions and conclusion}

As described above, there is now considerable basic research in producing photoreceptors from PSCs and the perspectives for clinical application of cell therapy for photoreceptor replacement seem promising. Nonetheless, there are many key issues to validate before taking this into the clinic: i) adequate production and purification of donor cell types with elimination of contaminating cells, 2) improvement of cell transplantation approaches, 3) immunogenicity and long-term graft survival.

To move to clinical applications, all phases of generation of retinal cells must be performed following current GMP guidelines with clinical grade lines of human ESCs or iPSCs, which must be generated using a non-integrative approach and cultivated with chemically defined products. With a few feeder-free and xeno-free differentiation protocols already reported (Reichman et al., 2017; Wiley et al., 2016), further efforts are required to improve reproducibility and scalability. It is also indispensable that these GMP-compliant protocols include steps of storage and purification of the human ESC or iPSC retinal derivates. Indeed, the development of appropriate cryopreservation methods suitable for photoreceptor precursors will be important to have access to cells at any time. Encouraging data reporting the use of cryopreserved retinal organoids as a source of transplantable photoreceptor precursors (Gagliardi et al., 2018) provide a relevant option of frozen stocks of differentiating retinal cells. Isolation of human ESC/iPSC-derived photoreceptor precursors from an undifferentiated cell population is absolutely required for the future transplantation of a homogenous and safe population of cells. Targeting of CD73, alone or in combination with 
other surface antigens, could be used for isolation of photoreceptors from human fetal retinas (Lakowski et al., 2018) and human retinal organoids (Gagliardi et al., 2018; Lidgerwood et al., 2018).

The new interpretation of the mechanisms associated with photoreceptor transplantation has reopened questions about the optimal developmental stage, maturation and functional integration capabilities of transplanted cells. It is now established that when the transplantation is performed in an animal recipient model with residual ONL, functional improvements as well phenotypic rescue may be mediated by the exchange of cytoplasmic material between host and donor photoreceptors. It is important to further define when the host/donor material exchange can happen and to understand the mechanisms underlying this process. Having excluded the complete cell-cell fusion and the uptake of free molecules, transient cell-cell connections, tunneling nanotubes or vesicular transports should be investigated (Nickerson et al., 2018; Santos-Ferreira et al., 2017; Zhou et al., 2018). We also need to investigate the cell material exchange phenomenon in different transplantation scenarios, such as in allografts and xenografts in non-human primates and lastly in humans. The elucidation of material exchange processes could lead to new therapeutic options for cell therapy applications, in which donor cells can be considered as a vector to deliver a missing protein or other molecules to the endogenous mutated photoreceptors. For example, rod $\alpha$ transducin was detected in Gnat1-/- recipients following transplantation of wild-type photoreceptor precursors (Pearson et al., 2016). For the repair of cardiac tissue, it has been shown that cell-free components, such as exosomes, are the main mediators of regenerative responses in target cells, as stem cell-derived exosomes recapitulated the same effects obtained with stem cell therapy (Khan et al., 2015; Singla, 2016). A similar approach may be considered for the treatment of certain photoreceptor degenerative diseases, at least for the stages in which the ONL is totally or partially intact. 
Current photoreceptor replacement strategies with PSC-derivatives, transplanted either as retinal sheet or as a photoreceptor cell suspension, showed some limitations (Figure 5). Retinal sheet transplants could lead to some functional restoration (Mandai et al., 2017a; McLelland et al., 2018; Shirai et al., 2016); nevertheless, the presence of retinal cell types other than photoreceptors, as well as the assembling into neural rosettes reduces the ability of transplanted retinal cells to reconnect within the host tissue and restore the visual function. On the contrary, transplantation of cell suspensions, if appropriately selected, can lead to a homogenous population of photoreceptors, although only a fraction of these cells can survive after the injection (Gagliardi et al., 2018). A remaining obstacle is that such transplanted cells have to develop into functional photoreceptors. Transplanted cells not only have to connect to the inner host retina, but also to develop light-sensitive outer segments. This requires interaction with the underlying RPE that maintains the photoreceptor structure and function via continuous disc shedding and renewal, including the regeneration of visual pigments in order to maintain the light sensitivity (Strauss, 2005). In all of the photoreceptor replacement strategies presented in this review, the photoreceptor morphological and functional maturation is still unsatisfactory in the transplanted cells, despite the expression of mature photoreceptor markers. Engineering scaffolds to support the photoreceptor maturation and polarization, as largely developed for RPE cell replacement strategies (Ben M’Barek et al., 2017; da Cruz et al., 2018; Hunt et al., 2018; Kashani et al., 2018), have started being developed in attempt to overcome these problems (Figure 5). Advancements in 3D printing technologies have made possible the creation of polymers with tightly controlled structure, in addition to chemical and mechanical features. Two-photon polymerization, a high-resolution 3D printing technique, has been used to create structures that facilitated the alignment of RPCs, maximizing their density on the surface and facilitating nutrient diffusion throughout the scaffold (Worthington et al., 2017). Validating the ability of 
these cells to differentiate into mature photoreceptors with formation of an outer segment structure as well as their in vivo functionality will be the next challenge. A novel microscaffold enabling to package transplantable photoreceptors has been recently reported. The "wine glass" scaffold designed by Jung and collaborators promoted organization and polarization of human PSC-derived photoreceptors (Jung et al., 2018) that is well-suited for cell replacement therapy. Bioprinting should allow to precisely control the distribution of cells on scaffolds and to obtain multi-layered structures combining RPE and photoreceptors, as recently demonstrated using both RPE and retinoblastoma cell lines (Shi et al., 2018). This approach could provide more appropriate treatment for advanced stages of AMD, when both RPE and photoreceptors need to be replaced.

An alternative option, given the difficulty of transplanted photoreceptors to form functional outer segments, may be offered by the combination of stem cell therapy with optogenetics to artificially confer light sensitivity to the donor cells. Based on the strategy to convert surviving retinal cells into light-sensitive cells (Busskamp et al., 2012), targeting dormant cones lacking light-sensitive outer segments with AAV expressing hyperpolarizing microbial opsin can restore light sensitivity in mouse models of retinitis pigmentosa (Busskamp et al., 2010). The introduction of optogenetic sensors in PSC-derived photoreceptor precursors could bypass the need for a functional maturation of transplanted cells, while preserving the localization of photosensitive cells as initial triggers in the transmission chain of visual signal. Furthermore, the insertion of light-sensors into PSC-derived photoreceptor precursors would make transplanted cells immediately able to respond to light, independently of the formation of outer segments and the presence of RPE. Optimization of major key-elements (AAV subtype, Promoter, microbial opsin trafficking) to ensure the safety and the efficacy of microbial opsins to establish reliable optogenetic therapies for retinal diseases is already well advanced (Khabou et al., 2018; Simunovic et al., 2019). Downstream transmission of visual 
signals to the other retinal neurons relies obviously on the capacity of transplanted cells to form synaptic connections with the host INL. Additionally, the major obstacle to clinical translation of this technology is that the microbial opsins used so far would not be activated in normal daylight, requiring illumination at specific wavelengths and intensities. Further engineering of new light-sensors together with improved integration of transplanted cells may represent substantial advancements for the efficacy of cell replacement using optogenetic sensor-expressing iPSC-derived photoreceptor precursors.

The achievement of fully successful photoreceptor replacement will rely on coimplementation of multiple strategies in all the steps leading to a cell therapy application, from cell product manufacturing, to surgical delivering and functional restoration. While significant hurdles need to be addressed before achieving any therapeutic ends, most of these open challenges do not concern exclusively the development of outer retinal cell therapies, but they are common to all stem cell-based treatments. Collaborative efforts from not only distinct stem cell domains, but also different scientific disciplines (biologists, engineers and clinicians) should accelerate the progress of regenerative medicine. Together these developments are likely to bring iPSC applications to clinical trials and whilst many challenges remain, they offer a hope for patients with untreatable retinal diseases to preserve, improve or restore visual function. 


\section{References}

Adler, R., Canto-Soler, M.V., 2007. Molecular mechanisms of optic vesicle development: Complexities, ambiguities and controversies. Dev. Biol. 305, 1-13. https://doi.org/10.1016/j.ydbio.2007.01.045

Akimoto, M., Cheng, H., Zhu, D., Brzezinski, J.A., Khanna, R., Filippova, E., Oh, E.C.T., Jing, Y., Linares, J.-L., Brooks, M., Zareparsi, S., Mears, A.J., Hero, A., Glaser, T., Swaroop, A., 2006. Targeting of GFP to newborn rods by Nrl promoter and temporal expression profiling of flow-sorted photoreceptors. Proc. Natl. Acad. Sci. U. S. A. 103, 3890-3895. https://doi.org/10.1073/pnas.0508214103

Aldiri, I., Xu, B., Wang, L., Chen, X., Hiler, D., Griffiths, L., Valentine, M., Shirinifard, A., Thiagarajan, S., Sablauer, A., Barabas, M.E., Zhang, J., Johnson, D., Frase, S., Zhou, X., Easton, J., Zhang, J., Mardis, E.R., Wilson, R.K., Downing, J.R., Dyer, M.A., 2017. The Dynamic Epigenetic Landscape of the Retina During Development, Reprogramming, and Tumorigenesis. Neuron 94, 550-568. https://doi.org/10.1016/j.neuron.2017.04.022

Allikmets, R., Singh, N., Sun, H., Shroyer, N.F., Hutchinson, A., Chidambaram, A., Gerrard, B., Baird, L., Stauffer, D., Peiffer, A., Rattner, A., Smallwood, P., Li, Y., Anderson, K.L., Lewis, R.A., Nathans, J., Leppert, M., Dean, M., Lupski, J.R., 1997. A photoreceptor cell-specific ATP-binding transporter gene (ABCR) is mutated in recessive Starqardt macular dystrophy. Nat. Genet. 15, 236-246. https://doi.org/10.1038/ng0397-236

Amirpour, N., Karamali, F., Rabiee, F., Rezaei, L., Esfandiari, E., Razavi, S., Dehghani, A., Razmju, H., Nasr-Esfahani, M.H., Baharvand, H., 2012. Differentiation of Human Embryonic Stem Cell-Derived Retinal Progenitors into Retinal Cells by Sonic Hedgehog and/or Retinal Pigmented Epithelium and Transplantation into the Subretinal Space of Sodium Iodate-Injected Rabbits. Stem Cells Dev. 21, 42-53. https://doi.org/10.1089/scd.2011.0073

Assawachananont, J., Mandai, M., Okamoto, S., Yamada, C., Eiraku, M., Yonemura, S., Sasai, Y., Takahashi, M., 2014. Transplantation of Embryonic and Induced Pluripotent Stem Cell-Derived 3D Retinal Sheets into Retinal Degenerative Mice. Stem Cell Reports 2, 662-674. https://doi.org/10.1016/j.stemcr.2014.03.011

Banin, E., Obolensky, A., Idelson, M., Hemo, I., Reinhardtz, E., Pikarsky, E., Ben-Hur, T., Reubinoff, B., 2006. Retinal Incorporation and Differentiation of Neural Precursors Derived from Human Embryonic Stem Cells. Stem Cells 24, 246-257. https://doi.org/10.1634/stemcells.2005-0009

Barber, A.C., Hippert, C., Duran, Y., West, E.L., Bainbridge, J.W.B., Warre-Cornish, K., Luhmann, U.F.O., Lakowski, J., Sowden, J.C., Ali, R.R., Pearson, R.A., 2013. Repair of the degenerate retina by photoreceptor transplantation. Proc. Natl. Acad. Sci. 110, 354359. https://doi.org/10.1073/pnas. 1212677110

Barnea-Cramer, A.O., Wang, W., Lu, S.-J., Singh, M.S., Luo, C., Huo, H., McClements, M.E., Barnard, A.R., MacLaren, R.E., Lanza, R., 2016. Function of human pluripotent stem cell-derived photoreceptor progenitors in blind mice. Sci. Rep. 6, 29784. https://doi.org/10.1038/srep29784

Bassett, E.A., Wallace, V.A., 2012. Cell fate determination in the vertebrate retina. Trends Neurosci. 35, 565-573. https://doi.org/10.1016/j.tins.2012.05.004

Ben M'Barek, K., Habeler, W., Plancheron, A., Jarraya, M., Regent, F., Terray, A., Yang, Y., 
Chatrousse, L., Domingues, S., Masson, Y., Sahel, J.-A., Peschanski, M., Goureau, O., Monville, C., 2017. Human ESC-derived retinal epithelial cell sheets potentiate rescue of photoreceptor cell loss in rats with retinal degeneration. Sci. Transl. Med. 9, eaai7471. https://doi.org/10.1126/scitranslmed.aai7471

Berger, W., Kloeckener-Gruissem, B., Neidhardt, J., 2010. The molecular basis of human retinal and vitreoretinal diseases. Prog. Retin. Eye Res. 29, 335-375.

https://doi.org/10.1016/j.preteyeres.2010.03.004

Boije, H., MacDonald, R.B., Harris, W.A., 2014. Reconciling competence and transcriptional hierarchies with stochasticity in retinal lineages. Curr. Opin. Neurobiol. 27, 68-74. https://doi.org/10.1016/j.conb.2014.02.014

Boucherie, C., Mukherjee, S., Henckaerts, E., Thrasher, A.J., Sowden, J.C., Ali, R.R., 2013. Brief Report: Self-Organizing Neuroepithelium from Human Pluripotent Stem Cells Facilitates Derivation of Photoreceptors. Stem Cells 31, 408-414. https://doi.org/10.1002/stem.1268

Bourne, R.R.A., Flaxman, S.R., Braithwaite, T., Cicinelli, M.V., Das, A., Jonas, J.B., Keeffe, J., Kempen, J.H., Leasher, J., Limburg, H., Naidoo, K., Pesudovs, K., Resnikoff, S., Silvester, A., Stevens, G.A., Tahhan, N., Wong, T.Y., Taylor, H.R., Bourne, R., Ackland, P., Arditi, A., Barkana, Y., Bozkurt, B., BRAITHWAITE, T., Bron, A., Budenz, D., Cai, F., Casson, R., Chakravarthy, U., Choi, J., Cicinelli, M.V., Congdon, N., Dana, R., Dandona, R., Dandona, L., Das, A., Dekaris, I., Del Monte, M., Deva, J., Dreer, L., Ellwein, L., Frazier, M., Frick, K., Friedman, D., Furtado, J., Gao, H., Gazzard, G., George, R., Gichuhi, S., Gonzalez, V., Hammond, B., Hartnett, M.E., He, M., Hejtmancik, J., Hirai, F., Huang, J., Ingram, A., Javitt, J., Jonas, J., Joslin, C., Keeffe, J., Kempen, J., Khairallah, M., Khanna, R., Kim, J., Lambrou, G., Lansingh, V.C., Lanzetta, P., Leasher, J., Lim, J., LIMBURG, H., Mansouri, K., Mathew, A., Morse, A., Munoz, B., Musch, D., Naidoo, K., Nangia, V., PALAIOU, M., Parodi, M.B., Pena, F.Y., Pesudovs, K., Peto, T., Quigley, H., Raju, M., Ramulu, P., Resnikoff, S., Robin, A., Rossetti, L., Saaddine, J., SANDAR, M., Serle, J., Shen, T., Shetty, R., Sieving, P., Silva, J.C., Silvester, A., Sitorus, R.S., Stambolian, D., Stevens, G., Taylor, H., Tejedor, J., Tielsch, J., Tsilimbaris, M., van Meurs, J., Varma, R., Virgili, G., Volmink, J., Wang, Y.X., Wang, N.-L., West, S., Wiedemann, P., Wong, T., Wormald, R., Zheng, Y., 2017. Magnitude, temporal trends, and projections of the global prevalence of blindness and distance and near vision impairment: a systematic review and meta-analysis. Lancet Glob. Heal. 5, e888-e897. https://doi.org/10.1016/S2214109X(17)30293-0

Brzezinski, J.A., Reh, T.A., 2015. Photoreceptor cell fate specification in vertebrates. Development 142, 3263-3273. https://doi.org/10.1242/dev.127043

Brzezinski, J.A., Uoon Park, K., Reh, T.A., 2013. Blimp1 (Prdm1) prevents re-specification of photoreceptors into retinal bipolar cells by restricting competence. Dev. Biol. 384, 194-204. https://doi.org/10.1016/j.ydbio.2013.10.006

Busskamp, V., Duebel, J., Balya, D., Fradot, M., Viney, T.J., Siegert, S., Groner, A.C., Cabuy, E., Forster, V., Seeliger, M., Biel, M., Humphries, P., Paques, M., Mohand-Said, S., Trono, D., Deisseroth, K., Sahel, J.A., Picaud, S., Roska, B., 2010. Genetic Reactivation of Cone Photoreceptors Restores Visual Responses in Retinitis Pigmentosa. Science (80-. ). 329, 413-417. https://doi.org/10.1126/science.1190897

Busskamp, V., Picaud, S., Sahel, J.A., Roska, B., 2012. Optogenetic therapy for retinitis pigmentosa. Gene Ther. 19, 169-175. https://doi.org/10.1038/gt.2011.155 
Capowski, E.E., Samimi, K., Mayerl, S.J., Phillips, M.J., Pinilla, I., Howden, S.E., Saha, J., Jansen, A.D., Edwards, K.L., Jager, L.D., Barlow, K., Valiauga, R., Erlichman, Z., Hagstrom, A., Sinha, D., Sluch, V.M., Chamling, X., Zack, D.J., Skala, M.C., Gamm, D.M., 2019. Reproducibility and staging of 3D human retinal organoids across multiple pluripotent stem cell lines. Development 146, dev171686.

https://doi.org/10.1242/dev.171686

Cepko, C., 2014. Intrinsically different retinal progenitor cells produce specific types of progeny. Nat. Rev. Neurosci. 15, 615-627. https://doi.org/10.1038/nrn3767

Chao, J.R., Lamba, D.A., Klesert, T.R., Torre, A. La, Hoshino, A., Taylor, R.J., Jayabalu, A., Engel, A.L., Khuu, T.H., Wang, R.K., Neitz, M., Neitz, J., Reh, T.A., 2017. Transplantation of Human Embryonic Stem Cell-Derived Retinal Cells into the Subretinal Space of a Non-Human Primate. Transl. Vis. Sci. Technol. 6, 4. https://doi.org/10.1167/tvst.6.3.4

Chen, J., 2005. The Rod Photoreceptor-Specific Nuclear Receptor Nr2e3 Represses Transcription of Multiple Cone-Specific Genes. J. Neurosci. 25, 118-129. https://doi.org/10.1523/JNEUROSCI.3571-04.2005

Chen, S., Wang, Q.L., Nie, Z., Sun, H., Lennon, G., Copeland, N.G., Gilbert, D.J., Jenkins, N.A., Zack, D.J., 1997. Crx, a novel Otx-like paired-homeodomain protein, binds to and transactivates photoreceptor cell-specific genes. Neuron 19, 1017-1030.

Cheng, D.L., Greenberg, P.B., Borton, D.A., 2017. Advances in Retinal Prosthetic Research: A Systematic Review of Engineering and Clinical Characteristics of Current Prosthetic Initiatives. Curr. Eye Res. 42, 334-347. https://doi.org/10.1080/02713683.2016.1270326

Cheng, H., Aleman, T.S., Cideciyan, A. V, Khanna, R., Jacobson, S.G., Swaroop, A., 2006. In vivo function of the orphan nuclear receptor NR2E3 in establishing photoreceptor identity during mammalian retinal development. Hum. Mol. Genet. 15, 2588-2602. https://doi.org/10.1093/hmg/dd1185

Chichagova, V., Hallam, D., Collin, J., Zerti, D., Dorgau, B., Felemban, M., Lako, M., Steel, D.H., 2018. Cellular regeneration strategies for macular degeneration: past, present and future. Eye 32, 946-971. https://doi.org/10.1038/s41433-018-0061-z

Cuenca, N., Fernández-Sánchez, L., McGill, T.J., Lu, B., Wang, S., Lund, R., Huhn, S., Capela, A., 2013. Phagocytosis of Photoreceptor Outer Segments by Transplanted Human Neural Stem Cells as a Neuroprotective Mechanism in Retinal Degeneration. Investig. Opthalmology Vis. Sci. 54, 6745-6756. https://doi.org/10.1167/iovs.13-12860

da Cruz, L., Fynes, K., Georgiadis, O., Kerby, J., Luo, Y.H., Ahmado, A., Vernon, A., Daniels, J.T., Nommiste, B., Hasan, S.M., Gooljar, S.B., Carr, A.-J.F., Vugler, A., Ramsden, C.M., Bictash, M., Fenster, M., Steer, J., Harbinson, T., Wilbrey, A., Tufail, A., Feng, G., Whitlock, M., Robson, A.G., Holder, G.E., Sagoo, M.S., Loudon, P.T., Whiting, P., Coffey, P.J., 2018. Phase 1 clinical study of an embryonic stem cell-derived retinal pigment epithelium patch in age-related macular degeneration. Nat. Biotechnol. 36, 328-337. https://doi.org/10.1038/nbt.4114

Daiger, S.P., Sullivan, L.S., Bowne, S.J., 2013. Genes and mutations causing retinitis pigmentosa. Clin. Genet. 84, 132-141. https://doi.org/10.1111/cge.12203

Dalkara, D., Goureau, O., Marazova, K., Sahel, J.-A., 2016. Let There Be Light: Gene and Cell Therapy for Blindness. Hum. Gene Ther. 27, 134-147.

https://doi.org/10.1089/hum.2015.147 
Decembrini, S., Koch, U., Radtke, F., Moulin, A., Arsenijevic, Y., 2014. Derivation of Traceable and Transplantable Photoreceptors from Mouse Embryonic Stem Cells. Stem Cell Reports 2, 853-865. https://doi.org/10.1016/j.stemcr.2014.04.010

Decembrini, S., Martin, C., Sennlaub, F., Chemtob, S., Biel, M., Samardzija, M., Moulin, A., Behar-Cohen, F., Arsenijevic, Y., 2017. Cone Genesis Tracing by the Chrnb4 -EGFP Mouse Line: Evidences of Cellular Material Fusion after Cone Precursor Transplantation. Mol. Ther. 25, 634-653. https://doi.org/10.1016/j.ymthe.2016.12.015

den Hollander, A.I., Roepman, R., Koenekoop, R.K., Cremers, F.P.M., 2008. Leber congenital amaurosis: Genes, proteins and disease mechanisms. Prog. Retin. Eye Res. 27, 391-419. https://doi.org/10.1016/j.preteyeres.2008.05.003

Dias, M.F., Joo, K., Kemp, J.A., Fialho, S.L., da Silva Cunha, A., Woo, S.J., Kwon, Y.J., 2018. Molecular genetics and emerging therapies for retinitis pigmentosa: Basic research and clinical perspectives. Prog. Retin. Eye Res. 63, 107-131. https://doi.org/10.1016/j.preteyeres.2017.10.004

Eberle, D., Kurth, T., Santos-Ferreira, T., Wilson, J., Corbeil, D., Ader, M., 2012. Outer Segment Formation of Transplanted Photoreceptor Precursor Cells. PLoS One 7, e46305. https://doi.org/10.1371/journal.pone.0046305

Eberle, D., Schubert, S., Postel, K., Corbeil, D., Ader, M., 2011. Increased Integration of Transplanted CD73-Positive Photoreceptor Precursors into Adult Mouse Retina. Investig. Opthalmology Vis. Sci. 52, 6462-6471. https://doi.org/10.1167/iovs.11-7399

Eiraku, M., Takata, N., Ishibashi, H., Kawada, M., Sakakura, E., Okuda, S., Sekiguchi, K., Adachi, T., Sasai, Y., 2011. Self-organizing optic-cup morphogenesis in threedimensional culture. Nature 472, 51-56. https://doi.org/10.1038/nature09941

Emerson, M.M., Surzenko, N., Goetz, J.J., Trimarchi, J., Cepko, C.L., 2013. Otx2 and Onecutl promote the fates of cone photoreceptors and horizontal cells and repress rod photoreceptors. Dev. Cell 26, 59-72. https://doi.org/10.1016/j.devcel.2013.06.005

Ferris, F.L., Wilkinson, C.P., Bird, A., Chakravarthy, U., Chew, E., Csaky, K., Sadda, S.R., 2013. Clinical Classification of Age-related Macular Degeneration. Ophthalmology 120, 844-851. https://doi.org/10.1016/j.ophtha.2012.10.036

Flaxman, S.R., Bourne, R.R.A., Resnikoff, S., Ackland, P., Braithwaite, T., Cicinelli, M.V., Das, A., Jonas, J.B., Keeffe, J., Kempen, J.H., Leasher, J., Limburg, H., Naidoo, K., Pesudovs, K., Silvester, A., Stevens, G.A., Tahhan, N., Wong, T.Y., Taylor, H.R., Bourne, R., Ackland, P., Arditi, A., Barkana, Y., Bozkurt, B., Braithwaite, T., Bron, A., Budenz, D., Cai, F., Casson, R., Chakravarthy, U., Choi, J., Cicinelli, M.V., Congdon, N., Dana, R., Dandona, R., Dandona, L., Das, A., Dekaris, I., Del Monte, M., Deva, J., Dreer, L., Ellwein, L., Frazier, M., Frick, K., Friedman, D., Furtado, J., Gao, H., Gazzard, G., George, R., Gichuhi, S., Gonzalez, V., Hammond, B., Hartnett, M.E., He, M., Hejtmancik, J., Hirai, F., Huang, J., Ingram, A., Javitt, J., Jonas, J., Joslin, C., Keeffe, J., Kempen, J., Khairallah, M., Khanna, R., Kim, J., Lambrou, G., Lansingh, V.C., Lanzetta, P., Leasher, J., Lim, J., LIMBURG, H., Mansouri, K., Mathew, A., Morse, A., Munoz, B., Musch, D., Naidoo, K., Nangia, V., Palaiou, M., Parodi, M.B., Pena, F.Y., Pesudovs, K., Peto, T., Quigley, H., Raju, M., Ramulu, P., Rankin, Z., Resnikoff, S., Reza, D., Robin, A., Rossetti, L., Saaddine, J., Sandar, M., Serle, J., Shen, T., Shetty, R., Sieving, P., Silva, J.C., Silvester, A., Sitorus, R.S., Stambolian, D., Stevens, G., Taylor, H., Tejedor, J., Tielsch, J., Tsilimbaris, M., van Meurs, J., Varma, R., Virgili, G., Wang, Y.X., Wang, N.-L., West, S., Wiedemann, P., Wong, T., Wormald, 
R., Zheng, Y., 2017. Global causes of blindness and distance vision impairment 19902020: a systematic review and meta-analysis. Lancet Glob. Heal. 5, e1221-e1234. https://doi.org/10.1016/S2214-109X(17)30393-5

Fritsche, L.G., Chen, W., Schu, M., Yaspan, B.L., Yu, Y., Thorleifsson, G., Zack, D.J., Arakawa, S., Cipriani, V., Ripke, S., Igo, R.P., Buitendijk, G.H.S., Sim, X., Weeks, D.E., Guymer, R.H., Merriam, J.E., Francis, P.J., Hannum, G., Agarwal, A., Armbrecht, A.M., Audo, I., Aung, T., Barile, G.R., Benchaboune, M., Bird, A.C., Bishop, P.N., Branham, K.E., Brooks, M., Brucker, A.J., Cade, W.H., Cain, M.S., Campochiaro, P.A., Chan, C.C., Cheng, C.-Y., Chew, E.Y., Chin, K.A., Chowers, I., Clayton, D.G., Cojocaru, R., Conley, Y.P., Cornes, B.K., Daly, M.J., Dhillon, B., Edwards, A.O., Evangelou, E., Fagerness, J., Ferreyra, H.A., Friedman, J.S., Geirsdottir, A., George, R.J., Gieger, C., Gupta, N., Hagstrom, S.A., Harding, S.P., Haritoglou, C., Heckenlively, J.R., Holz, F.G., Hughes, G., Ioannidis, J.P.A., Ishibashi, T., Joseph, P., Jun, G., Kamatani, Y., Katsanis, N., N Keilhauer, C., Khan, J.C., Kim, I.K., Kiyohara, Y., Klein, B.E.K., Klein, R., Kovach, J.L., Kozak, I., Lee, C.J., Lee, K.E., Lichtner, P., Lotery, A.J., Meitinger, T., Mitchell, P., Mohand-Saïd, S., Moore, A.T., Morgan, D.J., Morrison, M.A., Myers, C.E., Naj, A.C., Nakamura, Y., Okada, Y., Orlin, A., Ortube, M.C., Othman, M.I., Pappas, C., Park, K.H., Pauer, G.J.T., Peachey, N.S., Poch, O., Priya, R.R., Reynolds, R., Richardson, A.J., Ripp, R., Rudolph, G., Ryu, E., Sahel, J.-A., Schaumberg, D.A., Scholl, H.P.N., Schwartz, S.G., Scott, W.K., Shahid, H., Sigurdsson, H., Silvestri, G., Sivakumaran, T.A., Smith, R.T., Sobrin, L., Souied, E.H., Stambolian, D.E., Stefansson, H., Sturgill-Short, G.M., Takahashi, A., Tosakulwong, N., Truitt, B.J., Tsironi, E.E., Uitterlinden, A.G., van Duijn, C.M., Vijaya, L., Vingerling, J.R., Vithana, E.N., Webster, A.R., Wichmann, H.-E., Winkler, T.W., Wong, T.Y., Wright, A.F., Zelenika, D., Zhang, M., Zhao, L., Zhang, K., Klein, M.L., Hageman, G.S., Lathrop, G.M., Stefansson, K., Allikmets, R., Baird, P.N., Gorin, M.B., Wang, J.J., Klaver, C.C.W., Seddon, J.M., Pericak-Vance, M.A., Iyengar, S.K., Yates, J.R.W., Swaroop, A., Weber, B.H.F., Kubo, M., DeAngelis, M.M., Léveillard, T., Thorsteinsdottir, U., Haines, J.L., Farrer, L.A., Heid, I.M., Abecasis, G.R., 2013. Seven new loci associated with age-related macular degeneration. Nat. Genet. 45, 433-439. https://doi.org/10.1038/ng.2578

Fuhrmann, S., 2010. Eye Morphogenesis and Patterning of the Optic Vesicle, in: Current Topics in Developmental Biology. pp. 61-84. https://doi.org/10.1016/B978-0-12385044-7.00003-5

Fuhrmann, S., Zou, C., Levine, E.M., 2014. Retinal pigment epithelium development, plasticity, and tissue homeostasis. Exp. Eye Res. 123, 141-150. https://doi.org/10.1016/j.exer.2013.09.003

Fujieda, H., Bremner, R., Mears, A.J., Sasaki, H., 2009. Retinoic acid receptor-related orphan receptor $\alpha$ regulates a subset of cone genes during mouse retinal development. J. Neurochem. 108, 91-101. https://doi.org/10.1111/j.1471-4159.2008.05739.x

Furukawa, T., Morrow, E.M., Cepko, C.L., 1997. Crx, a novel otx-like homeobox gene, shows photoreceptor-specific expression and regulates photoreceptor differentiation. Cell 91, 531-541.

Gagliardi, G., Ben M'Barek, K., Chaffiol, A., Slembrouck-Brec, A., Conart, J.-B., Nanteau, C., Rabesandratana, O., Sahel, J.-A., Duebel, J., Orieux, G., Reichman, S., Goureau, O., 2018. Characterization and Transplantation of CD73-Positive Photoreceptors Isolated from Human iPSC-Derived Retinal Organoids. Stem Cell Reports 11, 665-680. https://doi.org/10.1016/j.stemcr.2018.07.005 
Gamm, D.M., Wang, S., Lu, B., Girman, S., Holmes, T., Bischoff, N., Shearer, R.L., Sauvé, Y., Capowski, E., Svendsen, C.N., Lund, R.D., 2007. Protection of Visual Functions by Human Neural Progenitors in a Rat Model of Retinal Disease. PLoS One 2, e338. https://doi.org/10.1371/journal.pone.0000338

Gomes, F.L.A.F., Zhang, G., Carbonell, F., Correa, J.A., Harris, W.A., Simons, B.D., Cayouette, M., 2011. Reconstruction of rat retinal progenitor cell lineages in vitro reveals a surprising degree of stochasticity in cell fate decisions. Development 138, 227 235. https://doi.org/10.1242/dev.059683

Gonzalez-Cordero, A., Kruczek, K., Naeem, A., Fernando, M., Kloc, M., Ribeiro, J., Goh, D., Duran, Y., Blackford, S.J.I., Abelleira-Hervas, L., Sampson, R.D., Shum, I.O., Branch, M.J., Gardner, P.J., Sowden, J.C., Bainbridge, J.W.B., Smith, A.J., West, E.L., Pearson, R.A., Ali, R.R., 2017. Recapitulation of Human Retinal Development from Human Pluripotent Stem Cells Generates Transplantable Populations of Cone Photoreceptors. Stem Cell Reports 9, 820-837. https://doi.org/10.1016/j.stemcr.2017.07.022

Gonzalez-Cordero, A., West, E.L., Pearson, R.A., Duran, Y., Carvalho, L.S., Chu, C.J., Naeem, A., Blackford, S.J.I., Georgiadis, A., Lakowski, J., Hubank, M., Smith, A.J., Bainbridge, J.W.B., Sowden, J.C., Ali, R.R., 2013. Photoreceptor precursors derived from three-dimensional embryonic stem cell cultures integrate and mature within adult degenerate retina. Nat. Biotechnol. 31, 741-747. https://doi.org/10.1038/nbt.2643

González, F., Boué, S., Belmonte, J.C.I., 2011. Methods for making induced pluripotent stem cells: reprogramming à la carte. Nat. Rev. Genet. 12, 231-242. https://doi.org/10.1038/nrg2937

Gourraud, P.-A., Gilson, L., Girard, M., Peschanski, M., 2012. The Role of Human Leukocyte Antigen Matching in the Development of Multiethnic "Haplobank" of Induced Pluripotent Stem Cell Lines. Stem Cells 30, 180-186. https://doi.org/10.1002/stem.772

Graw, J., 2010. Eye Development, in: Current Topics in Developmental Biology. pp. 343386. https://doi.org/10.1016/S0070-2153(10)90010-0

Guillonneau, X., Eandi, C.M., Paques, M., Sahel, J.-A., Sapieha, P., Sennlaub, F., 2017. On phagocytes and macular degeneration. Prog. Retin. Eye Res. 61, 98-128. https://doi.org/10.1016/j.preteyeres.2017.06.002

Haider, N.B., Cruz, N.M., Allocca, M., Yuan, J., 2014. Pathobiology of the Outer Retina: Genetic and Nongenetic Causes of Disease. Pathobiol. Hum. Dis. https://doi.org/http://dx.doi.org/10.1016/B978-0-12-386456-7.04706-7

Haji Abdollahi, S., Hirose, T., 2013. Stargardt-Fundus Flavimaculatus: Recent Advancements and Treatment. Semin. Ophthalmol. 28, 372-376. https://doi.org/10.3109/08820538.2013.825286

Hambright, D., Park, K.-Y., Brooks, M., McKay, R., Swaroop, A., Nasonkin, I.O., 2012. Long-term survival and differentiation of retinal neurons derived from human embryonic stem cell lines in un-immunosuppressed mouse retina. Mol. Vis. 18, 920-936.

Hamel, C., 2006. Retinitis pigmentosa. Orphanet J. Rare Dis. 1, 40. https://doi.org/10.1186/1750-1172-1-40

Hartong, D.T., Berson, E.L., Dryja, T.P., 2006. Retinitis pigmentosa. Lancet 368, 1795-809. https://doi.org/10.1016/S0140-6736(06)69740-7

Hatakeyama, J., Kageyama, R., 2004. Retinal cell fate determination and bHLH factors. Semin. Cell Dev. Biol. 15, 83-89. https://doi.org/10.1016/j.semcdb.2003.09.005 
He, J., Zhang, G., Almeida, A.D., Cayouette, M., Simons, B.D., Harris, W.A., 2012. How Variable Clones Build an Invariant Retina. Neuron 75, 786-798. https://doi.org/10.1016/j.neuron.2012.06.033

Hennig, A.K., Peng, G.-H., Chen, S., 2008. Regulation of photoreceptor gene expression by Crx-associated transcription factor network. Brain Res. 1192, 114-133. https://doi.org/10.1016/j.brainres.2007.06.036

Hirami, Y., Osakada, F., Takahashi, K., Okita, K., Yamanaka, S., Ikeda, H., Yoshimura, N., Takahashi, M., 2009. Generation of retinal cells from mouse and human induced pluripotent stem cells. Neurosci. Lett. 458, 126-131. https://doi.org/10.1016/j.neulet.2009.04.035

Homma, K., Okamoto, S., Mandai, M., Gotoh, N., Rajasimha, H.K., Chang, Y.-S., Chen, S., Li, W., Cogliati, T., Swaroop, A., Takahashi, M., 2013. Developing Rods Transplanted into the Degenerating Retina of Crx-Knockout Mice Exhibit Neural Activity Similar to Native Photoreceptors. Stem Cells 31, 1149-1159. https://doi.org/10.1002/stem. 1372

Hoshino, A., Ratnapriya, R., Brooks, M.J., Chaitankar, V., Wilken, M.S., Zhang, C., Starostik, M.R., Gieser, L., La Torre, A., Nishio, M., Bates, O., Walton, A., Bermingham-McDonogh, O., Glass, I.A., Wong, R.O.L., Swaroop, A., Reh, T.A., 2017. Molecular Anatomy of the Developing Human Retina. Dev. Cell 43, 763-779.e4. https://doi.org/10.1016/j.devcel.2017.10.029

Hunt, N.C., Hallam, D., Chichagova, V., Steel, D.H., Lako, M., 2018. The Application of Biomaterials to Tissue Engineering Neural Retina and Retinal Pigment Epithelium. Adv. Healthc. Mater. 7, 1800226. https://doi.org/10.1002/adhm.201800226

Ikeda, H., Osakada, F., Watanabe, K., Mizuseki, K., Haraguchi, T., Miyoshi, H., Kamiya, D., Honda, Y., Sasai, N., Yoshimura, N., Takahashi, M., Sasai, Y., 2005. Generation of $\mathrm{Rx}+/$ Pax6+ neural retinal precursors from embryonic stem cells. Proc. Natl. Acad. Sci. 102, 11331-11336. https://doi.org/10.1073/pnas.0500010102

Iraha, S., Tu, H.Y., Yamasaki, S., Kagawa, T., Goto, M., Takahashi, R., Watanabe, T., Sugita, S., Yonemura, S., Sunagawa, G.A., Matsuyama, T., Fujii, M., Kuwahara, A., Kishino, A., Koide, N., Eiraku, M., Tanihara, H., Takahashi, M., Mandai, M., 2018. Establishment of Immunodeficient Retinal Degeneration Model Mice and Functional Maturation of Human ESC-Derived Retinal Sheets after Transplantation. Stem Cell Reports 10, 1059-1074. https://doi.org/10.1016/j.stemcr.2018.01.032

Jadhav, A.P., 2006. Notch 1 inhibits photoreceptor production in the developing mammalian retina. Development 133, 913-923. https://doi.org/10.1242/dev.02245

Jia, L., Oh, E.C.T., Ng, L., Srinivas, M., Brooks, M., Swaroop, A., Forrest, D., 2009. Retinoid-related orphan nuclear receptor ROR is an early-acting factor in rod photoreceptor development. Proc. Natl. Acad. Sci. 106, 17534-17539. https://doi.org/10.1073/pnas.0902425106

Jin, Z.-B., Okamoto, S., Osakada, F., Homma, K., Assawachananont, J., Hirami, Y., Iwata, T., Takahashi, M., 2011. Modeling Retinal Degeneration Using Patient-Specific Induced Pluripotent Stem Cells. PLoS One 6, e17084. https://doi.org/10.1371/journal.pone.0017084

Jones, M.K., Lu, B., Girman, S., Wang, S., 2017. Cell-based therapeutic strategies for replacement and preservation in retinal degenerative diseases. Prog. Retin. Eye Res. 58, 1-27. https://doi.org/10.1016/j.preteyeres.2017.01.004 
Jung, Y.H., Phillips, M.J., Lee, J., Xie, R., Ludwig, A.L., Chen, G., Zheng, Q., Kim, T.J., Zhang, H., Barney, P., Min, J., Barlow, K., Gong, S., Gamm, D.M., Ma, Z., 2018. 3D Microstructured Scaffolds to Support Photoreceptor Polarization and Maturation. Adv. Mater. 30, 1803550. https://doi.org/10.1002/adma.201803550

Kaewkhaw, R., Kaya, K.D., Brooks, M., Homma, K., Zou, J., Chaitankar, V., Rao, M., Swaroop, A., 2015. Transcriptome Dynamics of Developing Photoreceptors in ThreeDimensional Retina Cultures Recapitulates Temporal Sequence of Human Cone and Rod Differentiation Revealing Cell Surface Markers and Gene Networks. Stem Cells 33, 3504-3518. https://doi.org/10.1002/stem.2122

Karagiannis, P., Takahashi, K., Saito, M., Yoshida, Y., Okita, K., Watanabe, A., Inoue, H., Yamashita, J.K., Todani, M., Nakagawa, M., Osawa, M., Yashiro, Y., Yamanaka, S., Osafune, K., 2019. Induced Pluripotent Stem Cells and Their Use in Human Models of Disease and Development. Physiol. Rev. 99, 79-114.

https://doi.org/10.1152/physrev.00039.2017

Kashani, A.H., Lebkowski, J.S., Rahhal, F.M., Avery, R.L., Salehi-Had, H., Dang, W., Lin, C.-M., Mitra, D., Zhu, D., Thomas, B.B., Hikita, S.T., Pennington, B.O., Johnson, L. V., Clegg, D.O., Hinton, D.R., Humayun, M.S., 2018. A bioengineered retinal pigment epithelial monolayer for advanced, dry age-related macular degeneration. Sci. Transl. Med. 10, eaao4097. https://doi.org/10.1126/scitranslmed.aao4097

Katoh, K., Omori, Y., Onishi, A., Sato, S., Kondo, M., Furukawa, T., 2010. Blimp1 Suppresses Chx10 Expression in Differentiating Retinal Photoreceptor Precursors to Ensure Proper Photoreceptor Development. J. Neurosci. 30, 6515-6526. https://doi.org/10.1523/JNEUROSCI.0771-10.2010

Khabou, H., Garita-Hernandez, M., Chaffiol, A., Reichman, S., Jaillard, C., Brazhnikova, E., Bertin, S., Forster, V., Desrosiers, M., Winckler, C., Goureau, O., Picaud, S., Duebel, J., Sahel, J.-A., Dalkara, D., 2018. Noninvasive gene delivery to foveal cones for vision restoration. JCI Insight 3. https://doi.org/10.1172/jci.insight.96029

Khan, M., Nickoloff, E., Abramova, T., Johnson, J., Verma, S.K., Krishnamurthy, P., Mackie, A.R., Vaughan, E., Garikipati, V.N.S., Benedict, C., Ramirez, V., Lambers, E., Ito, A., Gao, E., Misener, S., Luongo, T., Elrod, J., Qin, G., Houser, S.R., Koch, W.J., Kishore, R., 2015. Embryonic Stem Cell-Derived Exosomes Promote Endogenous Repair Mechanisms and Enhance Cardiac Function Following Myocardial Infarction. Circ. Res. 117, 52-64. https://doi.org/10.1161/CIRCRESAHA.117.305990

Koike, C., Nishida, A., Ueno, S., Saito, H., Sanuki, R., Sato, S., Furukawa, A., Aizawa, S., Matsuo, I., Suzuki, N., Kondo, M., Furukawa, T., 2007. Functional Roles of Otx2 Transcription Factor in Postnatal Mouse Retinal Development. Mol. Cell. Biol. 27, 8318-8329. https://doi.org/10.1128/MCB.01209-07

Koso, H., Minami, C., Tabata, Y., Inoue, M., Sasaki, E., Satoh, S., Watanabe, S., 2009. CD73, a Novel Cell Surface Antigen That Characterizes Retinal Photoreceptor Precursor Cells. Investig. Opthalmology Vis. Sci. 50, 54115-418. https://doi.org/10.1167/iovs.08-3246

Krohne, T.U., Westenskow, P.D., Kurihara, T., Friedlander, D.F., Lehmann, M., Dorsey, A.L., Li, W., Zhu, S., Schultz, A., Wang, J., Siuzdak, G., Ding, S., Friedlander, M., 2012. Generation of Retinal Pigment Epithelial Cells from Small Molecules and OCT4 Reprogrammed Human Induced Pluripotent Stem Cells. Stem Cells Transl. Med. 1, 96109. https://doi.org/10.5966/sctm.2011-0057

Kruczek, K., Gonzalez-Cordero, A., Goh, D., Naeem, A., Jonikas, M., Blackford, S.J.I., Kloc, 
M., Duran, Y., Georgiadis, A., Sampson, R.D., Maswood, R.N., Smith, A.J., Decembrini, S., Arsenijevic, Y., Sowden, J.C., Pearson, R.A., West, E.L., Ali, R.R., 2017. Differentiation and Transplantation of Embryonic Stem Cell-Derived Cone Photoreceptors into a Mouse Model of End-Stage Retinal Degeneration. Stem Cell Reports 8, 1659-1674. https://doi.org/10.1016/j.stemcr.2017.04.030

Kuwahara, A., Ozone, C., Nakano, T., Saito, K., Eiraku, M., Sasai, Y., 2015. Generation of a ciliary margin-like stem cell niche from self-organizing human retinal tissue. Nat. Commun. 6, 6286. https://doi.org/10.1038/ncomms7286

Lakowski, J., Gonzalez-Cordero, A., West, E.L., Han, Y.-T., Welby, E., Naeem, A., Blackford, S.J.I., Bainbridge, J.W.B., Pearson, R.A., Ali, R.R., Sowden, J.C., 2015. Transplantation of Photoreceptor Precursors Isolated via a Cell Surface Biomarker Panel from Embryonic Stem Cell-Derived Self-Forming Retina. Stem Cells 33, 2469-2482. https://doi.org/10.1002/stem.2051

Lakowski, J., Han, Y.-T., Pearson, R., Gonzalez-Cordero, A., West, E., Gualdoni, S., Barber, A., Hubank, M., Ali, R., Sowden, J., 2011. Effective Transplantation of Photoreceptor Precursor Cells Selected via Cell Surface Antigen Expression. Stem Cells 29, 13911404. https://doi.org/10.1002/stem.694

Lakowski, J., Welby, E., Budinger, D., Di Marco, F., Di Foggia, V., Bainbridge, J.W.B., Wallace, K., Gamm, D.M., Ali, R.R., Sowden, J.C., 2018. Isolation of Human Photoreceptor Precursors via a Cell Surface Marker Panel from Stem Cell-Derived Retinal Organoids and Fetal Retinae. Stem Cells 36, 709-722. https://doi.org/10.1002/stem.2775

Lamba, D.A., Gust, J., Reh, T.A., 2009. Transplantation of Human Embryonic Stem CellDerived Photoreceptors Restores Some Visual Function in Crx-Deficient Mice. Cell Stem Cell 4, 73-79. https://doi.org/10.1016/j.stem.2008.10.015

Lamba, D.A., Karl, M.O., Ware, C.B., Reh, T.A., 2006. Efficient generation of retinal progenitor cells from human embryonic stem cells. Proc. Natl. Acad. Sci. 103, 12769 12774. https://doi.org/10.1073/pnas.0601990103

Lamba, D.A., McUsic, A., Hirata, R.K., Wang, P.-R., Russell, D., Reh, T.A., 2010. Generation, Purification and Transplantation of Photoreceptors Derived from Human Induced Pluripotent Stem Cells. PLoS One 5, e8763. https://doi.org/10.1371/journal.pone.0008763

LaVail, M.M., Nishikawa, S., Steinberg, R.H., Naash, M.I., Duncan, J.L., Trautmann, N., Matthes, M.T., Yasumura, D., Lau-Villacorta, C., Chen, J., Peterson, W.M., Yang, H., Flannery, J.G., 2018. Phenotypic characterization of P23H and S334ter rhodopsin transgenic rat models of inherited retinal degeneration. Exp. Eye Res. 167, 56-90. https://doi.org/10.1016/j.exer.2017.10.023

Leach, L.L., Clegg, D.O., 2015. Concise Review: Making Stem Cells Retinal: Methods for Deriving Retinal Pigment Epithelium and Implications for Patients With Ocular Disease. Stem Cells 33, 2363-2373. https://doi.org/10.1002/stem.2010

Li, G., Xie, B., He, L., Zhou, T., Gao, G., Liu, S., Pan, G., Ge, J., Peng, F., Zhong, X., 2018. Generation of Retinal Organoids with Mature Rods and Cones from Urine-Derived Human Induced Pluripotent Stem Cells. Stem Cells Int. 2018, 1-12. https://doi.org/10.1155/2018/4968658

Lidgerwood, G.E., Morris, A.J., Conquest, A., Daniszewski, M., Rooney, L.A., Lim, S.Y., 
Hernández, D., Liang, H.H., Allen, P., Connell, P.P., Guymer, R.H., Hewitt, A.W., Pébay, A., 2018. Role of lysophosphatidic acid in the retinal pigment epithelium and photoreceptors. Biochim. Biophys. Acta - Mol. Cell Biol. Lipids 1863, 750-761. https://doi.org/10.1016/j.bbalip.2018.04.007

Liu, M.M., Zack, D.J., 2013. Alternative splicing and retinal degeneration. Clin. Genet. 84, 142-149. https://doi.org/10.1111/cge.12181

Livesey, F.J., Cepko, C.L., 2001. Vertebrate neural cell-fate determination: Lessons from the retina. Nat. Rev. Neurosci. 2, 109-118. https://doi.org/10.1038/35053522

Lolley, R.N., Rong, H., Craft, C.M., 1994. Linkage of photoreceptor degeneration by apoptosis with inherited defect in phototransduction. Investig. Ophthalmol. Vis. Sci. 35, $358-362$.

Lu, B., Morgans, C.W., Girman, S., Luo, J., Zhao, J., Du, H., Lim, S., Ding, S., Svendsen, C., Zhang, K., Wang, S., 2013. Neural Stem Cells Derived by Small Molecules Preserve Vision. Transl. Vis. Sci. Technol. 2, 1. https://doi.org/10.1167/tvst.2.1.1

Luo, J., Baranov, P., Patel, S., Ouyang, H., Quach, J., Wu, F., Qiu, A., Luo, H., Hicks, C., Zeng, J., Zhu, J., Lu, J., Sfeir, N., Wen, C., Zhang, M., Reade, V., Patel, S., Sinden, J., Sun, X., Shaw, P., Young, M., Zhang, K., 2014. Human Retinal Progenitor Cell Transplantation Preserves Vision. J. Biol. Chem. 289, 6362-6371. https://doi.org/10.1074/jbc.M113.513713

MacLaren, R.E., 2017. Cone fusion confusion in photoreceptor transplantation. Stem Cell Investig. 4, 71-71. https://doi.org/10.21037/sci.2017.08.02

MacLaren, R.E., Pearson, R.A., MacNeil, A., Douglas, R.H., Salt, T.E., Akimoto, M., Swaroop, A., Sowden, J.C., Ali, R.R., 2006. Retinal repair by transplantation of photoreceptor precursors. Nature 444, 203-207. https://doi.org/10.1038/nature05161

Mandai, M., Fujii, M., Hashiguchi, T., Sunagawa, G.A., Ito, S., Sun, J., Kaneko, J., Sho, J., Yamada, C., Takahashi, M., 2017a. iPSC-Derived Retina Transplants Improve Vision in rd1 End-Stage Retinal-Degeneration Mice. Stem Cell Reports 8, 69-83. https://doi.org/10.1016/j.stemcr.2016.12.008

Mandai, M., Watanabe, A., Kurimoto, Y., Hirami, Y., Morinaga, C., Daimon, T., Fujihara, M., Akimaru, H., Sakai, N., Shibata, Y., Terada, M., Nomiya, Y., Tanishima, S., Nakamura, M., Kamao, H., Sugita, S., Onishi, A., Ito, T., Fujita, K., Kawamata, S., Go, M.J., Shinohara, C., Hata, K.-I., Sawada, M., Yamamoto, M., Ohta, S., Ohara, Y., Yoshida, K., Kuwahara, J., Kitano, Y., Amano, N., Umekage, M., Kitaoka, F., Tanaka, A., Okada, C., Takasu, N., Ogawa, S., Yamanaka, S., Takahashi, M., 2017b. Autologous Induced Stem-Cell-Derived Retinal Cells for Macular Degeneration. N. Engl. J. Med. 376, 1038-1046. https://doi.org/10.1056/NEJMoa1608368

Mathur, P., Yang, J., 2015. Usher syndrome: Hearing loss, retinal degeneration and associated abnormalities. Biochim. Biophys. Acta - Mol. Basis Dis. 1852, 406-420. https://doi.org/10.1016/j.bbadis.2014.11.020

McLelland, B.T., Lin, B., Mathur, A., Aramant, R.B., Thomas, B.B., Nistor, G., Keirstead, H.S., Seiler, M.J., 2018. Transplanted hESC-Derived Retina Organoid Sheets Differentiate, Integrate, and Improve Visual Function in Retinal Degenerate Rats. Investig. Opthalmology Vis. Sci. 59, 2586-2603. https://doi.org/10.1167/iovs.17-23646

Mears, A.J., Kondo, M., Swain, P.K., Takada, Y., Bush, R.A., Saunders, T.L., Sieving, P.A., Swaroop, A., 2001. Nrl is required for rod photoreceptor development. Nat. Genet. 29, 
447-452. https://doi.org/10.1038/ng774

Mehat, M.S., Sundaram, V., Ripamonti, C., Robson, A.G., Smith, A.J., Borooah, S., Robinson, M., Rosenthal, A.N., Innes, W., Weleber, R.G., Lee, R.W.J., Crossland, M., Rubin, G.S., Dhillon, B., Steel, D.H.W., Anglade, E., Lanza, R.P., Ali, R.R., Michaelides, M., Bainbridge, J.W.B., 2018. Transplantation of Human Embryonic Stem Cell-Derived Retinal Pigment Epithelial Cells in Macular Degeneration. Ophthalmology 125, 1765-1775. https://doi.org/10.1016/j.ophtha.2018.04.037

Mellough, C.B., Bauer, R., Collin, J., Dorgau, B., Zerti, D., Dolan, D.W.P., Jones, C.M., Izuogu, O.G., Yu, M., Hallam, D., Steyn, J.S., White, K., Steel, D.H., Santibanez-Koref, M., Elliott, D.J., Jackson, M.S., Lindsay, S., Grellscheid, S., Lako, M., 2019. An integrated transcriptional analysis of the developing human retina. Development 146, dev169474. https://doi.org/10.1242/dev.169474

Mellough, C.B., Collin, J., Khazim, M., White, K., Sernagor, E., Steel, D.H.W., Lako, M., 2015. IGF-1 Signaling Plays an Important Role in the Formation of Three-Dimensional Laminated Neural Retina and Other Ocular Structures From Human Embryonic Stem Cells. Stem Cells 33, 2416-2430. https://doi.org/10.1002/stem.2023

Mellough, C.B., Sernagor, E., Moreno-Gimeno, I., Steel, D.H.W., Lako, M., 2012. Efficient Stage-Specific Differentiation of Human Pluripotent Stem Cells Toward Retinal Photoreceptor Cells. Stem Cells 30, 673-686. https://doi.org/10.1002/stem.1037

Meyer, J.S., Howden, S.E., Wallace, K.A., Verhoeven, A.D., Wright, L.S., Capowski, E.E., Pinilla, I., Martin, J.M., Tian, S., Stewart, R., Pattnaik, B., Thomson, J.A., Gamm, D.M., 2011. Optic Vesicle-like Structures Derived from Human Pluripotent Stem Cells Facilitate a Customized Approach to Retinal Disease Treatment. Stem Cells 29, 12061218. https://doi.org/10.1002/stem.674

Meyer, J.S., Shearer, R.L., Capowski, E.E., Wright, L.S., Wallace, K.A., McMillan, E.L., Zhang, S.-C., Gamm, D.M., 2009. Modeling early retinal development with human embryonic and induced pluripotent stem cells. Proc. Natl. Acad. Sci. 106, 16698-16703. https://doi.org/10.1073/pnas.0905245106

Mitchell, P., Liew, G., Gopinath, B., Wong, T.Y., 2018. Age-related macular degeneration. Lancet 392, 1147-1159. https://doi.org/10.1016/S0140-6736(18)31550-2

Mockel, A., Perdomo, Y., Stutzmann, F., Letsch, J., Marion, V., Dollfus, H., 2011. Retinal dystrophy in Bardet-Biedl syndrome and related syndromic ciliopathies. Prog. Retin. Eye Res. 30, 258-274. https://doi.org/10.1016/j.preteyeres.2011.03.001

Mustafi, D., Kevany, B.M., Bai, X., Golczak, M., Adams, M.D., Wynshaw-Boris, A., Palczewski, K., 2016. Transcriptome analysis reveals rod/cone photoreceptor specific signatures across mammalian retinas. Hum. Mol. Genet. 25, 4376-4388. https://doi.org/10.1093/hmg/ddw268

Nakano, T., Ando, S., Takata, N., Kawada, M., Muguruma, K., Sekiguchi, K., Saito, K., Yonemura, S., Eiraku, M., Sasai, Y., 2012. Self-Formation of Optic Cups and Storable Stratified Neural Retina from Human ESCs. Cell Stem Cell 10, 771-785. https://doi.org/10.1016/j.stem.2012.05.009

Nazari, H., Zhang, L., Zhu, D., Chader, G.J., Falabella, P., Stefanini, F., Rowland, T., Clegg, D.O., Kashani, A.H., Hinton, D.R., Humayun, M.S., 2015. Stem cell based therapies for age-related macular degeneration: The promises and the challenges. Prog. Retin. Eye Res. 48, 1-39. https://doi.org/10.1016/j.preteyeres.2015.06.004 
Neves, J., Zhu, J., Sousa-Victor, P., Konjikusic, M., Riley, R., Chew, S., Qi, Y., Jasper, H., Lamba, D.A., 2016. Immune modulation by MANF promotes tissue repair and regenerative success in the retina. Science (80-. ). 353, aaf3646-aaf3646. https://doi.org/10.1126/science.aaf3646

Ng, L., Hurley, J.B., Dierks, B., Srinivas, M., Saltó, C., Vennström, B., Reh, T.A., Forrest, D., 2001. A thyroid hormone receptor that is required for the development of green cone photoreceptors. Nat. Genet. 27, 94-98. https://doi.org/10.1038/83829

Nickerson, P.E.B., Ortin-Martinez, A., Wallace, V.A., 2018. Material Exchange in Photoreceptor Transplantation: Updating Our Understanding of Donor/Host Communication and the Future of Cell Engraftment Science. Front. Neural Circuits 12, 17. https://doi.org/10.3389/fncir.2018.00017

Nishida, A., Furukawa, A., Koike, C., Tano, Y., Aizawa, S., Matsuo, I., Furukawa, T., 2003. Otx2 homeobox gene controls retinal photoreceptor cell fate and pineal gland development. Nat. Neurosci. 6, 1255-1263. https://doi.org/10.1038/nn1155

Nolbrant, S., Heuer, A., Parmar, M., Kirkeby, A., 2017. Generation of high-purity human ventral midbrain dopaminergic progenitors for in vitro maturation and intracerebral transplantation. Nat. Protoc. 12, 1962-1979. https://doi.org/10.1038/nprot.2017.078

Oh, E.C.T., Cheng, H., Hao, H., Jia, L., Khan, N.W., Swaroop, A., 2008. Rod differentiation factor NRL activates the expression of nuclear receptor NR2E3 to suppress the development of cone photoreceptors. Brain Res. 1236, 16-29. https://doi.org/10.1016/j.brainres.2008.01.028

Ohsawa, R., Kageyama, R., 2008. Regulation of retinal cell fate specification by multiple transcription factors. Brain Res. 1192, 90-98. https://doi.org/10.1016/j.brainres.2007.04.014

Ortin-Martinez, A., Tsai, E.L.S., Nickerson, P.E., Bergeret, M., Lu, Y., Smiley, S., Comanita, L., Wallace, V.A., 2017. A Reinterpretation of Cell Transplantation: GFP Transfer From Donor to Host Photoreceptors. Stem Cells 35, 932-939. https://doi.org/10.1002/stem.2552

Osakada, F., Ikeda, H., Mandai, M., Wataya, T., Watanabe, K., Yoshimura, N., Akaike, A., Sasai, Y., Takahashi, M., 2008. Toward the generation of rod and cone photoreceptors from mouse, monkey and human embryonic stem cells. Nat. Biotechnol. 26, 215-224. https://doi.org/10.1038/nbt1384

Osakada, F., Ikeda, H., Sasai, Y., Takahashi, M., 2009a. Stepwise differentiation of pluripotent stem cells into retinal cells. Nat. Protoc. 4, 811-824.

https://doi.org/10.1038/nprot.2009.51

Osakada, F., Jin, Z.-B., Hirami, Y., Ikeda, H., Danjyo, T., Watanabe, K., Sasai, Y., Takahashi, M., 2009b. In vitro differentiation of retinal cells from human pluripotent stem cells by small-molecule induction. J. Cell Sci. 122, 3169-3179. https://doi.org/10.1242/jcs.050393

Ovando-Roche, P., West, E.L., Branch, M.J., Sampson, R.D., Fernando, M., Munro, P., Georgiadis, A., Rizzi, M., Kloc, M., Naeem, A., Ribeiro, J., Smith, A.J., GonzalezCordero, A., Ali, R.R., 2018. Use of bioreactors for culturing human retinal organoids improves photoreceptor yields. Stem Cell Res. Ther. 9, 156. https://doi.org/10.1186/s13287-018-0907-0

Ozawa, Y., Nakao, K., Shimazaki, T., Takeda, J., Akira, S., Ishihara, K., Hirano, T., Oguchi, 
Y., Okano, H., 2004. Downregulation of STAT3 activation is required for presumptive rod photoreceptor cells to differentiate in the postnatal retina. Mol. Cell. Neurosci. 26, 258-270. https://doi.org/10.1016/j.men.2004.02.001

Pearson, R.A., 2014. Advances in repairing the degenerate retina by rod photoreceptor transplantation. Biotechnol. Adv. 32, 485-491. https://doi.org/10.1016/j.biotechadv.2014.01.001

Pearson, R.A., Barber, A.C., Rizzi, M., Hippert, C., Xue, T., West, E.L., Duran, Y., Smith, A.J., Chuang, J.Z., Azam, S.A., Luhmann, U.F.O., Benucci, A., Sung, C.H., Bainbridge, J.W., Carandini, M., Yau, K.-W., Sowden, J.C., Ali, R.R., 2012. Restoration of vision after transplantation of photoreceptors. Nature 485, 99-103. https://doi.org/10.1038/nature10997

Pearson, R.A., Gonzalez-Cordero, A., West, E.L., Ribeiro, J.R., Aghaizu, N., Goh, D., Sampson, R.D., Georgiadis, A., Waldron, P. V, Duran, Y., Naeem, A., Kloc, M., Cristante, E., Kruczek, K., Warre-Cornish, K., Sowden, J.C., Smith, A.J., Ali, R.R., 2016. Donor and host photoreceptors engage in material transfer following transplantation of post-mitotic photoreceptor precursors. Nat. Commun. 7, 13029. https://doi.org/10.1038/ncomms 13029

Peng, G.-H., Ahmad, O., Ahmad, F., Liu, J., Chen, S., 2005. The photoreceptor-specific nuclear receptor Nr2e 3 interacts with Crx and exerts opposing effects on the transcription of rod versus cone genes. Hum. Mol. Genet. 14, 747-764. https://doi.org/10.1093/hmg/ddi070

Phillips, M.J., Perez, E.T., Martin, J.M., Reshel, S.T., Wallace, K.A., Capowski, E.E., Singh, R., Wright, L.S., Clark, E.M., Barney, P.M., Stewart, R., Dickerson, S.J., Miller, M.J., Percin, E.F., Thomson, J.A., Gamm, D.M., 2014. Modeling human retinal development with patient-specific induced pluripotent stem cells reveals multiple roles for visual system homeobox 2. Stem Cells 32, 1480-92. https://doi.org/10.1002/stem.1667

Phillips, M.J., Wallace, K.A., Dickerson, S.J., Miller, M.J., Verhoeven, A.D., Martin, J.M., Wright, L.S., Shen, W., Capowski, E.E., Percin, E.F., Perez, E.T., Zhong, X., CantoSoler, M. V, Gamm, D.M., 2012. Blood-Derived Human iPS Cells Generate Optic Vesicle-Like Structures with the Capacity to Form Retinal Laminae and Develop Synapses. Investig. Opthalmology Vis. Sci. 53, 2007-2019. https://doi.org/10.1167/iovs.11-9313

Postel, K., Bellmann, J., Splith, V., Ader, M., 2013. Analysis of cell surface markers specific for transplantable rod photoreceptors. Mol. Vis. 19, 2058-2067.

Ramamurthy, V., Niemi, G.A., Reh, T.A., Hurley, J.B., 2004. Leber congenital amaurosis linked to AIPL1: A mouse model reveals destabilization of cGMP phosphodiesterase. Proc. Natl. Acad. Sci. 101, 13897-13902. https://doi.org/10.1073/pnas.0404197101

Reichman, S., Goureau, O., 2014. Production of Retinal Cells from Confluent Human iPS Cells, in: Methods in Molecular Biology (Clifton, N.J.). pp. 339-351. https://doi.org/10.1007/7651_2014_143

Reichman, S., Slembrouck, A., Gagliardi, G., Chaffiol, A., Terray, A., Nanteau, C., Potey, A., Belle, M., Rabesandratana, O., Duebel, J., Orieux, G., Nandrot, E.F., Sahel, J.-A., Goureau, O., 2017. Generation of Storable Retinal Organoids and Retinal Pigmented Epithelium from Adherent Human iPS Cells in Xeno-Free and Feeder-Free Conditions. Stem Cells 35, 1176-1188. https://doi.org/10.1002/stem.2586 
Reichman, S., Terray, A., Slembrouck, A., Nanteau, C., Orieux, G., Habeler, W., Nandrot, E.F., Sahel, J.-A., Monville, C., Goureau, O., 2014. From confluent human iPS cells to self-forming neural retina and retinal pigmented epithelium. Proc. Natl. Acad. Sci. 111, 8518-8523. https://doi.org/10.1073/pnas.1324212111

Rhee, K. Do, Goureau, O., Chen, S., Yang, X.-J., 2004. Cytokine-Induced Activation of Signal Transducer and Activator of Transcription in Photoreceptor Precursors Regulates Rod Differentiation in the Developing Mouse Retina. J. Neurosci. 24, 9779-9788. https://doi.org/10.1523/JNEUROSCI.1785-04.2004

Rhee, K. Do, Yang, X.-J., 2010. Function and Mechanism of CNTF/LIF Signaling in Retinogenesis, in: Advances in Experimental Medicine and Biology. pp. 647-654. https://doi.org/10.1007/978-1-4419-1399-9_74

Roberts, M.R., Hendrickson, A., McGuire, C.R., Reh, T.A., 2005. Retinoid X Receptor $\gamma$ Is Necessary to Establish the S-opsin Gradient in Cone Photoreceptors of the Developing Mouse Retina. Investig. Opthalmology Vis. Sci. 46, 2897-2904. https://doi.org/10.1167/iovs.05-0093

Santos-Ferreira, T., Llonch, S., Borsch, O., Postel, K., Haas, J., Ader, M., 2016a. Retinal transplantation of photoreceptors results in donor-host cytoplasmic exchange. Nat. Commun. 7, 13028. https://doi.org/10.1038/ncomms13028

Santos-Ferreira, T., Postel, K., Stutzki, H., Kurth, T., Zeck, G., Ader, M., 2015. Daylight Vision Repair by Cell Transplantation. Stem Cells 33, 79-90. https://doi.org/10.1002/stem.1824

Santos-Ferreira, T., Völkner, M., Borsch, O., Haas, J., Cimalla, P., Vasudevan, P., Carmeliet, P., Corbeil, D., Michalakis, S., Koch, E., Karl, M.O., Ader, M., 2016b. Stem CellDerived Photoreceptor Transplants Differentially Integrate Into Mouse Models of ConeRod Dystrophy. Investig. Opthalmology Vis. Sci. 57, 3509-3520. https://doi.org/10.1167/iovs.16-19087

Santos-Ferreira, T.F., Borsch, O., Ader, M., 2017. Rebuilding the Missing Part-A Review on Photoreceptor Transplantation. Front. Syst. Neurosci. 10, 105. https://doi.org/10.3389/fnsys.2016.00105

Satoh, S., Tang, K., Iida, A., Inoue, M., Kodama, T., Tsai, S.Y., Tsai, M.-J., Furuta, Y., Watanabe, S., 2009. The Spatial Patterning of Mouse Cone Opsin Expression Is Regulated by Bone Morphogenetic Protein Signaling through Downstream Effector COUP-TF Nuclear Receptors. J. Neurosci. 29, 12401-12411. https://doi.org/10.1523/JNEUROSCI.0951-09.2009

Schwartz, S.D., Regillo, C.D., Lam, B.L., Eliott, D., Rosenfeld, P.J., Gregori, N.Z., Hubschman, J., Davis, J.L., Heilwell, G., Spirn, M., Maguire, J., Gay, R., Bateman, J., Ostrick, R.M., Morris, D., Vincent, M., Anglade, E., Del Priore, L. V, Lanza, R., 2015. Human embryonic stem cell-derived retinal pigment epithelium in patients with agerelated macular degeneration and Stargardt's macular dystrophy: follow-up of two openlabel phase 1/2 studies. Lancet 385, 509-516. https://doi.org/10.1016/S01406736(14)61376-3

Seiler, M.J., Aramant, R.B., 2012. Cell replacement and visual restoration by retinal sheet transplants. Prog. Retin. Eye Res. 31, 661-687. https://doi.org/10.1016/j.preteyeres.2012.06.003

Shi, P., Tan, Y.S.E., Yeong, W.Y., Li, H.Y., Laude, A., 2018. A bilayer photoreceptor-retinal 
tissue model with gradient cell density design: A study of microvalve-based bioprinting. J. Tissue Eng. Regen. Med. 12, 1297-1306. https://doi.org/10.1002/term.2661

Shirai, H., Mandai, M., Matsushita, K., Kuwahara, A., Yonemura, S., Nakano, T., Assawachananont, J., Kimura, T., Saito, K., Terasaki, H., Eiraku, M., Sasai, Y., Takahashi, M., 2016. Transplantation of human embryonic stem cell-derived retinal tissue in two primate models of retinal degeneration. Proc. Natl. Acad. Sci. 113, E81E90. https://doi.org/10.1073/pnas.1512590113

Simunovic, M.P., Shen, W., Lin, J.Y., Protti, D.A., Lisowski, L., Gillies, M.C., 2019. Optogenetic approaches to vision restoration. Exp. Eye Res. 178, 15-26. https://doi.org/10.1016/j.exer.2018.09.003

Singh, M.S., Balmer, J., Barnard, A.R., Aslam, S.A., Moralli, D., Green, C.M., BarneaCramer, A., Duncan, I., MacLaren, R.E., 2016. Transplanted photoreceptor precursors transfer proteins to host photoreceptors by a mechanism of cytoplasmic fusion. Nat. Commun. 7, 13537. https://doi.org/10.1038/ncomms13537

Singh, M.S., Charbel Issa, P., Butler, R., Martin, C., Lipinski, D.M., Sekaran, S., Barnard, A.R., MacLaren, R.E., 2013. Reversal of end-stage retinal degeneration and restoration of visual function by photoreceptor transplantation. Proc. Natl. Acad. Sci. 110, 11011106. https://doi.org/10.1073/pnas.1119416110

Singh, R.K., Mallela, R.K., Cornuet, P.K., Reifler, A.N., Chervenak, A.P., West, M.D., Wong, K.Y., Nasonkin, I.O., 2015. Characterization of Three-Dimensional Retinal Tissue Derived from Human Embryonic Stem Cells in Adherent Monolayer Cultures. Stem Cells Dev. 24, 2778-2795. https://doi.org/10.1089/scd.2015.0144

Singla, D.K., 2016. Stem cells and exosomes in cardiac repair. Curr. Opin. Pharmacol. 27, 19-23. https://doi.org/10.1016/j.coph.2016.01.003

Smiley, S., Nickerson, P.E., Comanita, L., Daftarian, N., El-Sehemy, A., Tsai, E.L.S., MatanLithwick, S., Yan, K., Thurig, S., Touahri, Y., Dixit, R., Aavani, T., De Repentigny, Y., Baker, A., Tsilfidis, C., Biernaskie, J., Sauvé, Y., Schuurmans, C., Kothary, R., Mears, A.J., Wallace, V.A., 2016. Establishment of a cone photoreceptor transplantation platform based on a novel cone-GFP reporter mouse line. Sci. Rep. 6, 22867. https://doi.org/10.1038/srep22867

Song, W.K., Park, K.-M., Kim, H.-J., Lee, J.H., Choi, J., Chong, S.Y., Shim, S.H., Del Priore, L. V., Lanza, R., 2015. Treatment of Macular Degeneration Using Embryonic Stem CellDerived Retinal Pigment Epithelium: Preliminary Results in Asian Patients. Stem Cell Reports 4, 860-872. https://doi.org/10.1016/j.stemcr.2015.04.005

Strauss, O., 2005. The Retinal Pigment Epithelium in Visual Function. Physiol. Rev. 85, 845881. https://doi.org/10.1152/physrev.00021.2004

Sugita, S., Iwasaki, Y., Makabe, K., Kamao, H., Mandai, M., Shiina, T., Ogasawara, K., Hirami, Y., Kurimoto, Y., Takahashi, M., 2016. Successful Transplantation of Retinal Pigment Epithelial Cells from MHC Homozygote iPSCs in MHC-Matched Models. Stem Cell Reports 7, 635-648. https://doi.org/10.1016/j.stemcr.2016.08.010

Swaroop, A., Kim, D., Forrest, D., 2010. Transcriptional regulation of photoreceptor development and homeostasis in the mammalian retina. Nat. Rev. Neurosci. 11, 563576. https://doi.org/10.1038/nrn2880

Takahashi, K., Tanabe, K., Ohnuki, M., Narita, M., Ichisaka, T., Tomoda, K., Yamanaka, S., 2007. Induction of Pluripotent Stem Cells from Adult Human Fibroblasts by Defined 
Factors. Cell 131, 861-872. https://doi.org/10.1016/j.cell.2007.11.019

Taylor, C.J., Peacock, S., Chaudhry, A.N., Bradley, J.A., Bolton, E.M., 2012. Generating an iPSC Bank for HLA-Matched Tissue Transplantation Based on Known Donor and Recipient HLA Types. Cell Stem Cell 11, 147-152. https://doi.org/10.1016/j.stem.2012.07.014

Thomson, J.A., Itskovitz-Eldor, J., Shapiro, S.S., Waknitz, M.A., Swiergiel, J.J., Marshall, V.S., Jones, J.M., 1998. Embryonic stem cell lines derived from human blastocysts. Science (80-. ). 282, 1145-1147.

Tsai, Y., Lu, B., Bakondi, B., Girman, S., Sahabian, A., Sareen, D., Svendsen, C.N., Wang, S., 2015. Human iPSC-Derived Neural Progenitors Preserve Vision in an AMD-Like Model. Stem Cells 33, 2537-2549. https://doi.org/10.1002/stem.2032

Tu, H.-Y., Watanabe, T., Shirai, H., Yamasaki, S., Kinoshita, M., Matsushita, K., Hashiguchi, T., Onoe, H., Matsuyama, T., Kuwahara, A., Kishino, A., Kimura, T., Eiraku, M., Suzuma, K., Kitaoka, T., Takahashi, M., Mandai, M., 2019. Medium- to long-term survival and functional examination of human iPSC-derived retinas in rat and primate models of retinal degeneration. EBioMedicine 39, 562-574.

https://doi.org/10.1016/j.ebiom.2018.11.028

Tucker, B.A., Mullins, R.F., Streb, L.M., Anfinson, K., Eyestone, M.E., Kaalberg, E., Riker, M.J., Drack, A. V, Braun, T. a, Stone, E.M., 2013. Patient-specific iPSC-derived photoreceptor precursor cells as a means to investigate retinitis pigmentosa. Elife 2, e00824. https://doi.org/10.7554/eLife.00824

Tucker, B.A., Park, I.-H., Qi, S.D., Klassen, H.J., Jiang, C., Yao, J., Redenti, S., Daley, G.Q., Young, M.J., 2011. Transplantation of Adult Mouse iPS Cell-Derived Photoreceptor Precursors Restores Retinal Structure and Function in Degenerative Mice. PLoS One 6, e18992. https://doi.org/10.1371/journal.pone.0018992

Turner, D.L., Cepko, C.L., 1987. A common progenitor for neurons and glia persists in rat retina late in development. Nature 328, 131-136. https://doi.org/10.1038/328131a0

Turner, M., Leslie, S., Martin, N.G., Peschanski, M., Rao, M., Taylor, C.J., Trounson, A., Turner, D., Yamanaka, S., Wilmut, I., 2013. Toward the Development of a Global Induced Pluripotent Stem Cell Library. Cell Stem Cell 13, 382-384. https://doi.org/10.1016/j.stem.2013.08.003

Van Gelder, R.N., 2015. Photochemical approaches to vision restoration. Vision Res. 111, 134-141. https://doi.org/10.1016/j.visres.2015.02.001

Verbakel, S.K., van Huet, R.A.C., Boon, C.J.F., den Hollander, A.I., Collin, R.W.J., Klaver, C.C.W., Hoyng, C.B., Roepman, R., Klevering, B.J., 2018. Non-syndromic retinitis pigmentosa. Prog. Retin. Eye Res. 66, 157-186. https://doi.org/10.1016/j.preteyeres.2018.03.005

Viczian, A.S., Solessio, E.C., Lyou, Y., Zuber, M.E., 2009. Generation of Functional Eyes from Pluripotent Cells. PLoS Biol. 7, e1000174. https://doi.org/10.1371/journal.pbio.1000174

Völkner, M., Zschätzsch, M., Rostovskaya, M., Overall, R.W., Busskamp, V., Anastassiadis, K., Karl, M.O., 2016. Retinal Organoids from Pluripotent Stem Cells Efficiently Recapitulate Retinogenesis. Stem Cell Reports 6, 525-538. https://doi.org/10.1016/j.stemcr.2016.03.001

Wahlin, K.J., Maruotti, J.A., Sripathi, S.R., Ball, J., Angueyra, J.M., Kim, C., Grebe, R., Li, 
W., Jones, B.W., Zack, D.J., 2017. Photoreceptor Outer Segment-like Structures in Long-Term 3D Retinas from Human Pluripotent Stem Cells. Sci. Rep. 7, 766. https://doi.org/10.1038/s41598-017-00774-9

Waldron, P. V, Di Marco, F., Kruczek, K., Ribeiro, J., Graca, A.B., Hippert, C., Aghaizu, N.D., Kalargyrou, A.A., Barber, A.C., Grimaldi, G., Duran, Y., Blackford, S.J.I., Kloc, M., Goh, D., Zabala Aldunate, E., Sampson, R.D., Bainbridge, J.W.B., Smith, A.J., Gonzalez-Cordero, A., Sowden, J.C., Ali, R.R., Pearson, R.A., 2018. Transplanted Donor- or Stem Cell-Derived Cone Photoreceptors Can Both Integrate and Undergo Material Transfer in an Environment-Dependent Manner. Stem Cell Reports 10, 406421. https://doi.org/10.1016/j.stemcr.2017.12.008

Wang, X., Xiong, K., Lin, C., Lv, L., Chen, J., Xu, C., Wang, S., Gu, D., Zheng, H., Yu, H., Li, Y., Xiao, H., Zhou, G., 2015. New medium used in the differentiation of human pluripotent stem cells to retinal cells is comparable to fetal human eye tissue. Biomaterials 53, 40-49. https://doi.org/10.1016/j.biomaterials.2015.02.065

Welby, E., Lakowski, J., Di Foggia, V., Budinger, D., Gonzalez-Cordero, A., Lun, A.T.L., Epstein, M., Patel, A., Cuevas, E., Kruczek, K., Naeem, A., Minneci, F., Hubank, M., Jones, D.T., Marioni, J.C., Ali, R.R., Sowden, J.C., 2017. Isolation and Comparative Transcriptome Analysis of Human Fetal and iPSC-Derived Cone Photoreceptor Cells. Stem Cell Reports 9, 1898-1915. https://doi.org/10.1016/j.stemcr.2017.10.018

Wiley, L.A., Burnight, E.R., DeLuca, A.P., Anfinson, K.R., Cranston, C.M., Kaalberg, E.E., Penticoff, J.A., Affatigato, L.M., Mullins, R.F., Stone, E.M., Tucker, B.A., 2016. cGMP production of patient-specific iPSCs and photoreceptor precursor cells to treat retinal degenerative blindness. Sci. Rep. 6, 30742. https://doi.org/10.1038/srep30742

Worthington, K.S., Wiley, L.A., Kaalberg, E.E., Collins, M.M., Mullins, R.F., Stone, E.M., Tucker, B.A., 2017. Two-photon polymerization for production of human iPSC-derived retinal cell grafts. Acta Biomater. 55, 385-395.

https://doi.org/10.1016/j.actbio.2017.03.039

Yanai, A., Laver, C.R.J., Joe, A.W., Viringipurampeer, I.A., Wang, X., Gregory-Evans, C.Y., Gregory-Evans, K., 2013. Differentiation of Human Embryonic Stem Cells Using SizeControlled Embryoid Bodies and Negative Cell Selection in the Production of Photoreceptor Precursor Cells. Tissue Eng. Part C Methods 19, 755-764. https://doi.org/10.1089/ten.tec.2012.0524

Young, R.W., 1985. Cell differentiation in the retina of the mouse. Anat. Rec. 212, 199-205. https://doi.org/10.1002/ar.1092120215

Yue, L., Weiland, J.D., Roska, B., Humayun, M.S., 2016. Retinal stimulation strategies to restore vision: Fundamentals and systems. Prog. Retin. Eye Res. 53, 21-47. https://doi.org/10.1016/j.preteyeres.2016.05.002

Zeitz, C., Robson, A.G., Audo, I., 2015. Congenital stationary night blindness: An analysis and update of genotype-phenotype correlations and pathogenic mechanisms. Prog. Retin. Eye Res. 45, 58-110. https://doi.org/10.1016/j.preteyeres.2014.09.001

Zhong, X., Gutierrez, C., Xue, T., Hampton, C., Vergara, M.N., Cao, L.-H., Peters, A., Park, T.S., Zambidis, E.T., Meyer, J.S., Gamm, D.M., Yau, K.-W., Canto-Soler, M.V., 2014. Generation of three-dimensional retinal tissue with functional photoreceptors from human iPSCs. Nat. Commun. 5, 4047. https://doi.org/10.1038/ncomms5047

Zhou, J., Benito-Martin, A., Mighty, J., Chang, L., Ghoroghi, S., Wu, H., Wong, M., 
Guariglia, S., Baranov, P., Young, M., Gharbaran, R., Emerson, M., Mark, M.T., Molina, H., Canto-Soler, M.V., Selgas, H.P., Redenti, S., 2018. Retinal progenitor cells release extracellular vesicles containing developmental transcription factors, microRNA and membrane proteins. Sci. Rep. 8, 2823. https://doi.org/10.1038/s41598-018-20421-1

Zhou, S., Flamier, A., Abdouh, M., Tétreault, N., Barabino, A., Wadhwa, S., Bernier, G., 2015. Differentiation of human embryonic stem cells into cone photoreceptors through simultaneous inhibition of BMP, TGF $\beta$ and Wnt signaling. Development 142, 32943306. https://doi.org/10.1242/dev.125385

Zhu, J., Cifuentes, H., Reynolds, J., Lamba, D.A., 2017. Immunosuppression via Loss of IL2r $\gamma$ Enhances Long-Term Functional Integration of hESC-Derived Photoreceptors in the Mouse Retina. Cell Stem Cell 20, 374-384.e5. https://doi.org/10.1016/j.stem.2016.11.019

Zhu, J., Reynolds, J., Garcia, T., Cifuentes, H., Chew, S., Zeng, X., Lamba, D.A., 2018. Generation of Transplantable Retinal Photoreceptors from a Current Good Manufacturing Practice-Manufactured Human Induced Pluripotent Stem Cell Line. Stem Cells Transl. Med. 7, 210-219. https://doi.org/10.1002/sctm.17-0205

Zhu, Y., Carido, M., Meinhardt, A., Kurth, T., Karl, M.O., Ader, M., Tanaka, E.M., 2013. Three-Dimensional Neuroepithelial Culture from Human Embryonic Stem Cells and Its Use for Quantitative Conversion to Retinal Pigment Epithelium. PLoS One 8, e54552. https://doi.org/10.1371/journal.pone.0054552

Zuber, M.E., 2010. Eye Field Specification in Xenopus laevis, in: Cagan, Ross L;Reh, T.A. (Ed.), Current Topics in Developmental Biology. Elsevier Inc., pp. 29-60. https://doi.org/10.1016/B978-0-12-385044-7.00002-3 


\section{Legends of figures}

\section{Figure 1: Classification of inherited monogenic retinal diseases.}

Diseases are categorized according to the photoreceptor cell type primarily and predominantly affected. Cone dominated diseases are subdivided in stationary and progressive, while rod dominated and generalized photoreceptor diseases are mostly progressive. Only the progressive forms of non-syndromic or syndromic (associated with non-retinal disorders) were mentioned in the figure. RP: Retinitis Pigmentosa. *Dystrophies caused by BEST1 mutations are generally grouped as Bestrophinopathies. Names of syndromes in bold correspond to the most common syndromes in each category. Source:

https://sph.uth.edu/retnet/ (2018/11).

Figure 2: Schematic representation of eye, retinal and photoreceptor development. At early stages, the eye field territory is specified in an anterior region of the neural plate under the control of specific gradients of morphogens and growth factors. This domain extends laterally to form the optic vesicle and the optic cup after invagination. At this stage, specific morphogens and growth factors allow the specification of the future RPE and the future neural retina respectively in the outer and in the inner part of the developing optic cup. Within the neural retina, retinal progenitors were specified in different lineages, including the photoreceptor lineage. Further differentiation of committed post-mitotic photoreceptor precursors gives rise to fully mature rod or cone photoreceptors. BMP: Bone morphogenetic protein; FGF: Fibroblast Growth Factor; IGF: Insulin-like Growth Factor; SHH: Sonic Hedgehog; TGF $\beta$ : Transforming growth factor $\beta$. 
Figure 3: Schematic representation of key steps for the generation of retinal organoids from human PSCs.

Top panel illustrates the different steps to generate retinal organoids from adherent PSC cultures (detailed in Reichman et al. 2014, 2017 and Gonzalez-Cordero et al. 2017). Bottom panel shows the different 2D and 3D steps using PSC-derived embryoid bodies (detailed in Zhong et al. 2014, Kuwahara et al. 2015 and Capowski et al. 2019). iPSM: iPS media; NIM: Neural induction media; RDM: retinal differentiation media; RMM: retinal maturation media.

\section{Figure 4: Example of multiple strategies for the identification of human cells following} subretinal transplantation in the rhodopsin $\mathrm{P} 23 \mathrm{H}$ transgenic photoreceptor degenerative rat model.

(A-C) Transplanted human cells obtained from iPSC-derived retinal organoids identified by immunostaining with human specific antibodies against antigens localized in different cellular compartments, cytoplasm (A), nucleus (B) and mitochondria (C). (D-D”) Rat and human cells, display different nuclear morphology, with rat photoreceptors having smaller nuclei and condensed heterochromatin at their center, compared to bigger nuclei with multiple chromocenters in human cells, additionally identified by immunostaining against S121 in panel D; Panel D" corresponds to a high magnification of the area delimited in panel D'. (EE') FISH targeting human Y chromosome (green) combined with immunostaining for human cytoplasmic antigen S121 (red). All cells displaying a FISH signal also express S121 and bear typical human nuclear morphology. Analyses were performed four weeks following transplantation. Nuclei were counterstained with DAPI. Scale bars: $20 \mu \mathrm{m}$. Chr, chromosome; FISH, fluorescent in situ hybridization; GCL, Ganglion Cell Layer; HNA, Human Nuclear Antigen; INL, Inner Nuclear Layer; MTC02, Mitochondrial cytochrome c oxidase subunit 2; 
ONL, Outer Nuclear Layer; rPR, rat photoreceptors; SRS, Subretinal Space; S121, STEM 121.

Figure 5: Schematic illustrating the major strategies adopted so far in transplantation studies using human PSC-derived retinal organoids as source of retinal cells.

FACS, Fluorescence-Activated Cell Sorting; GCL, Ganglion Cell Layer; INL, Inner Nuclear Layer; MACS, Magnetic-Activated Cell Sorting; ONL, Outer Nuclear Layer; RPE, Retinal Pigment Epithelium; SRS, Subretinal Space. 


\section{Table 1: Principal protocols for the differentiation of hPSCs to photoreceptors}

Somatic cells used for reprogramming are indicated between brackets

\begin{tabular}{|c|c|c|c|c|}
\hline $\begin{array}{l}\text { Type of } \\
\text { pluripotent } \\
\text { stem cells } \\
\text { (source) }\end{array}$ & $\begin{array}{l}\text { Method of } \\
\text { differentiation }\end{array}$ & $\begin{array}{l}\text { Media } \\
\text { supplementation/ } \\
\text { Factors added }\end{array}$ & $\begin{array}{l}\text { Markers of photoreceptor } \\
\text { lineage and time for } \\
\text { detection } \\
\text { (immunohistochemistry) }\end{array}$ & References \\
\hline $\begin{array}{l}\text { hESCs } \\
\text { hiPSCs } \\
\text { (fibroblasts) }\end{array}$ & $\begin{array}{l}\text { Floating cultures (EB or } \\
\text { small clumps of cells), } \\
\text { followed by plating } \\
\text { (Matrigel coating). }\end{array}$ & $\begin{array}{l}\text { N2 and B27 / } \\
\text { IGF-1, Dkk1, Noggin } \\
\text { and FGF2 }\end{array}$ & $\begin{array}{l}\text { CRX, NRL }(D 20) \\
\text { RECOVERIN, } \\
\text { RHODOPSIN, S-OPSIN } \\
(D 60)\end{array}$ & $\begin{array}{l}\text { (Lamba et } \\
\text { al., 2006) } \\
\text { (Lamba et al., } \\
2010)\end{array}$ \\
\hline $\begin{array}{l}\text { hESCs } \\
\text { hiPSCs } \\
\text { (fibroblasts) }\end{array}$ & $\begin{array}{l}\text { Floating cultures (EB- } \\
\text { like aggregates), } \\
\text { followed by plating } \\
\text { (poly-Lysine /laminin/ } \\
\text { fibronectin coating). }\end{array}$ & $\begin{array}{l}\text { N2/ } \\
\text { Dkk1 (or CKI-7), } \\
\text { Lefty (or SB431542), } \\
\text { RA and taurine }\end{array}$ & $\begin{array}{l}\text { CRX, RECOVERIN }(D 50) \\
\text { NRL, RHODOPSIN, OPSIN } \\
(D 120)\end{array}$ & $\begin{array}{l}\text { (Osakada et } \\
\text { al., 2008) } \\
\text { (Hirami et al., } \\
\text { 2009; Jin et } \\
\text { al., 2011; } \\
\text { Osakada et } \\
\text { al., 2009a) }\end{array}$ \\
\hline $\begin{array}{l}\text { hESCs } \\
\text { hiPSCs } \\
\text { (fibroblasts, } \\
\text { T cells) }\end{array}$ & $\begin{array}{l}\text { Floating cultures (small } \\
\text { clumps of cells), } \\
\text { followed by plating } \\
\text { (laminin coating) and } \\
\text { isolation (D 20-25) of } \\
\text { self-forming optic } \\
\text { vesicle-like structures } \\
\text { (culture in suspension). }\end{array}$ & $\begin{array}{l}\mathrm{N} 2 \text { and B27 / } \\
\text { Optional: Noggin (or } \\
\text { Dorsomorphin) and } \\
\text { Dkk1 (or XAV939) }\end{array}$ & $\begin{array}{l}\text { CRX, NRL, RECOVERIN } \\
(D 40-D 70) \\
\text { RHODOPSIN, S-OPSIN } \\
(D 80-D 100)\end{array}$ & $\begin{array}{l}\text { (Meyer et al., } \\
\text { 2011) } \\
\text { (Meyer et al., } \\
\text { 2009; Phillips } \\
\text { et al., 2014, } \\
\text { 2012) }\end{array}$ \\
\hline hESCs & $\begin{array}{l}\text { Adherent cell cultures } \\
\text { followed by isolation of } \\
\text { "Neural tube-like } \\
\text { structures" (day 16) and } \\
\text { by plating (Laminin } \\
\text { /Poly-ornithin coating). }\end{array}$ & $\begin{array}{l}\text { N2 and B27 / } \\
\text { IGF-1, Dkk1, Noggin, } \\
\text { FGF2 } \\
\text { SHH (optional) }\end{array}$ & $\begin{array}{l}\text { RHODOPSIN, S-OPSIN } \\
(D 40-50)\end{array}$ & $\begin{array}{l}\text { (Amirpour } \\
\text { et al., 2012) }\end{array}$ \\
\hline $\begin{array}{l}\text { hESCs } \\
\text { hiPSCs } \\
\text { (fibroblasts) }\end{array}$ & $\begin{array}{l}\text { Floating cultures } \\
\text { (clumps of cells), } \\
\text { followed by isolation } \\
\text { (day } 30 \text { ) and plating } \\
\text { (Poly-ornithin / laminin } \\
\text { coating). }\end{array}$ & $\begin{array}{l}\text { N2 and B27 / } \\
\text { IGF-1, Dkk1, Noggin, } \\
\text { Lefty, SHH, T3, } \\
\text { FGF2, RA and taurine }\end{array}$ & $\begin{array}{l}\text { RHODOPSIN, S-OPSIN } \\
(D 45-60)\end{array}$ & $\begin{array}{l}\text { (Mellough et } \\
\text { al., 2012) }\end{array}$ \\
\hline hESCs & $\begin{array}{l}\text { Floating cultures (EB- } \\
\text { like aggregates) in } 1 \% \\
\text { Matrigel: self- } \\
\text { formation of optic cup } \\
\text { structures. }\end{array}$ & $\begin{array}{l}\text { KSR, FBS, N2 / } \\
\text { IWR1e (Wnt } \\
\text { inhibitor), SAG (SHH } \\
\text { mimetic), } \\
\text { CHIR99021 (GSK3 } \\
\text { inhibitor), RA and } \\
\text { taurine, }\end{array}$ & $\begin{array}{l}\text { CRX, RECOVERIN (D35 - } \\
40) \\
\text { NRL, RHODOPSIN, S- } \\
\text { OPSIN }(D 120)\end{array}$ & $\begin{array}{l}\text { (Nakano et } \\
\text { al., 2012) } \\
\text { (Kuwahara et } \\
\text { al., 2015) }\end{array}$ \\
\hline hESCs & $\begin{array}{l}\text { Floating cultures } \\
\text { (clumps of cells) in } \\
\text { presence of Matrigel } \\
\text { followed by isolation } \\
\text { (day 5) and plating } \\
\text { (Matrigel coating). }\end{array}$ & $\mathrm{N} 2$ and B27 / & $\mathrm{CRX}(D 20-40)$ & $\begin{array}{l}\text { (Zhu et al., } \\
\text { 2013) }\end{array}$ \\
\hline $\begin{array}{l}\text { hESCs } \\
\text { hiPSCs }\end{array}$ & $\begin{array}{l}\text { Floating cultures } \\
\text { (clumps of cells) in } \\
\text { presence of Matrigel. }\end{array}$ & $\begin{array}{l}\text { N2 and B27 / } \\
\text { SHH, T3, FGF1, } \\
\text { FGF2, RA and taurine }\end{array}$ & $\begin{array}{l}\text { CRX }(D 10) \\
\text { RHODOPSIN }(D 30)\end{array}$ & $\begin{array}{l}\text { (Boucherie } \\
\text { et al., 2013) }\end{array}$ \\
\hline
\end{tabular}




\begin{tabular}{|c|c|c|c|c|}
\hline $\begin{array}{l}\text { hiPSCs } \\
\text { (fibroblasts, } \\
\text { keratinocytes) }\end{array}$ & $\begin{array}{l}\text { Floating cultures (EBs) } \\
\text { followed by isolation } \\
\text { (day 5) and plating } \\
\text { (synthemax culture } \\
\text { plates): self-formation } \\
\text { of eye cup structures }\end{array}$ & $\begin{array}{l}\text { N2 and B27 / } \\
\text { IGF-1, Dkk1, Noggin, } \\
\text { FGF2, DAPT and } \\
\text { FGF1 }\end{array}$ & $\begin{array}{l}\text { RECOVERIN }(D 90) \\
\text { RHODOPSIN }(D 120)\end{array}$ & $\begin{array}{l}\text { (Tucker et } \\
\text { al., 2013) }\end{array}$ \\
\hline hESCs & $\begin{array}{l}\text { Floating cultures (Size- } \\
\text { calibrated EBs) } \\
\text { followed by isolation } \\
\text { (day 4) and plating } \\
\text { (Matrigel coating). }\end{array}$ & $\begin{array}{l}\text { N2 and B27 / } \\
\text { Noggin, DKK1, } \\
\text { IGF1, FGF2, taurine } \\
\text { and T3 }\end{array}$ & CRX (D20) & $\begin{array}{l}\text { (Yanai et al., } \\
\text { 2013) }\end{array}$ \\
\hline $\begin{array}{l}\text { hiPSCs } \\
\text { (fibroblasts) }\end{array}$ & $\begin{array}{l}\text { Adherent cell cultures } \\
\text { followed by isolation } \\
\text { (day 24) of self- } \\
\text { forming neural-retina } \\
\text { structures (culture in } \\
\text { suspension). }\end{array}$ & N2 /B27 & $\begin{array}{l}\text { CRX }(D 25-30) \\
\text { RECOVERIN, CD73 (D35- } \\
50) \\
\text { RHODOPSIN, L/M-OPSIN } \\
(D 90-D 120)\end{array}$ & $\begin{array}{l}\text { (Reichman } \\
\text { et al., 2014) } \\
\text { (Reichman et } \\
\text { al., 2017; } \\
\text { Reichman } \\
\text { and Goureau, } \\
\text { 2014) }\end{array}$ \\
\hline $\begin{array}{l}\text { hiPSCs } \\
\text { (fibroblasts) }\end{array}$ & $\begin{array}{l}\text { Floating cultures (small } \\
\text { clumps of cells), } \\
\text { followed by plating } \\
\text { (Matrigel coating) and } \\
\text { isolation (D21-28) of } \\
\text { self-forming retinal } \\
\text { structures (culture in } \\
\text { suspension). }\end{array}$ & $\begin{array}{l}\mathrm{N} 2 \text { and } \mathrm{B} 27 \text { and FBS } \\
\text { / Heparin, RA and } \\
\text { taurine }\end{array}$ & $\begin{array}{l}\text { RECOVERIN }(D 100) \\
\text { TRANSDUCIN, } \\
\text { RHODOPSIN, S-OPSIN, } \\
\text { L/M-OPSIN }(D 120-150)\end{array}$ & $\begin{array}{l}\text { (Zhong et al., } \\
\text { 2014) } \\
\text { (Li et al., } \\
2018 \text { ) }\end{array}$ \\
\hline hESCs & $\begin{array}{l}\text { Adherent cell cultures } \\
\text { followed by isolation } \\
\text { (D16) of self-forming } \\
\text { neuro-epithelial } \\
\text { structures (culture in } \\
\text { suspension). }\end{array}$ & $\begin{array}{l}\text { N2 and KSR / } \\
\text { FGF2, Nicotinamide }\end{array}$ & $\mathrm{CRX}(D 40-45)$ & $\begin{array}{l}\text { (Wang et al., } \\
\text { 2015) }\end{array}$ \\
\hline hESCs & $\begin{array}{l}\text { Floating cultures } \\
\text { (clumps of cells). }\end{array}$ & $\begin{array}{l}\text { KSR, N2 and B27 / } \\
\text { IGF-1, Dkk1, Noggin, } \\
\text { Lefty, SHH, T3, } \\
\text { FGF2, RA and taurine }\end{array}$ & $\begin{array}{l}\text { S-OPSIN }(D 30) \\
\text { CRX, RECOVERIN and } \\
\text { RHODOPSIN }(D 90)\end{array}$ & $\begin{array}{l}\text { (Mellough et } \\
\text { al., 2015) }\end{array}$ \\
\hline hESCs & $\begin{array}{l}\text { Adherent cells cultures } \\
\text { (Matrigel coating). }\end{array}$ & $\begin{array}{l}\text { N2 and B27 / } \\
\text { IGF-1, Dkk1, Noggin, } \\
\text { FGF2, and FGF9 }\end{array}$ & $\begin{array}{l}\text { CRX }(D 40-45) \\
\text { RECOVERIN } \\
\text { PNA }\end{array}$ & $\begin{array}{l}\text { (Singh et al., } \\
\text { 2015) }\end{array}$ \\
\hline hESCs & $\begin{array}{l}\text { Floating cultures (EBs), } \\
\text { followed by plating } \\
\text { (Matrigel coating). }\end{array}$ & $\begin{array}{l}\text { N2 and B27 / } \\
\text { IGF-1, Dkk1, Noggin, } \\
\text { FGF2, and COCO }\end{array}$ & $\begin{array}{l}\text { CRX and S-OPSIN (D21) } \\
\text { No NRL and RHODOPSIN }\end{array}$ & $\begin{array}{l}\text { (Zhou et al., } \\
\text { 2015) }\end{array}$ \\
\hline $\begin{array}{l}\text { hESCs } \\
\text { hiPSCs }\end{array}$ & $\begin{array}{l}\text { Adherent cells cultures } \\
\text { (Matrigel coating), } \\
\text { followed by culture of } \\
\text { neural spheres (D19-23) } \\
\text { and re-plating on } \\
\text { Matrigel coating. }\end{array}$ & $\begin{array}{l}\text { N2, B27 / } \\
\text { Insulin, Noggin, } \\
\text { BDNF, CTNF, DAPT } \\
\text { and RA }\end{array}$ & $\begin{array}{l}\text { CRX, NRL, NR2E3 (D90- } \\
D 100)\end{array}$ & $\begin{array}{l}\text { (Barnea- } \\
\text { Cramer et } \\
\text { al., 2016) }\end{array}$ \\
\hline hESCs & $\begin{array}{l}\text { Floating cultures (EB- } \\
\text { like aggregates) in } 2 \% \\
\text { Matrigel: self- } \\
\text { formation of optic cup } \\
\text { structures, followed by } \\
\text { (D18) manually } \\
\text { dissection of retinal } \\
\text { organoids in } 3-5 \text { parts } \\
\text { (floating culture). }\end{array}$ & $\begin{array}{l}\text { KSR, FBS, N2 / } \\
\text { IWR1e, SAG, EC23 } \\
\text { (synthetic retinoid) }\end{array}$ & Not reported & $\begin{array}{l}\text { (Völkner et } \\
\text { al., 2016) }\end{array}$ \\
\hline
\end{tabular}




\begin{tabular}{|c|c|c|c|c|}
\hline $\begin{array}{l}\text { hESCs } \\
\text { hiPSCs }\end{array}$ & $\begin{array}{l}\text { Adherent cell cultures } \\
\text { followed by isolation } \\
\text { (D28-49) of } \\
\text { neuroretinal vesicles } \\
\text { (culture in suspension). }\end{array}$ & $\begin{array}{l}\text { N2 and B27 and FBS } \\
/ \\
\text { RA and taurine }\end{array}$ & $\begin{array}{l}\text { RECOVERIN }(D 70), \\
\text { RHODOPSIN }(D 105), \text { S- } \\
\text { OPSIN }(D 84), \text { L/M-OPSIN } \\
(D 120)\end{array}$ & $\begin{array}{l}\text { (Gonzalez- } \\
\text { Cordero et } \\
\text { al., 2017) } \\
\text { (Ovando- } \\
\text { Roche et al., } \\
2018 \text { ) }\end{array}$ \\
\hline $\begin{array}{l}\text { hESCs } \\
\text { hiPSCs }\end{array}$ & $\begin{array}{l}\text { Floating cultures (EB- } \\
\text { like aggregates) in } 1 \% \\
\text { Matrigel: self- } \\
\text { formation of optic cup } \\
\text { structures. }\end{array}$ & $\begin{array}{l}\text { B27 FBS / } \\
\text { IWR1, SAG, RA, } \\
\text { DAPT and taurine }\end{array}$ & $\begin{array}{l}\text { RECOVERIN }(D 45) \text {, } \\
\text { RHODOPSIN, L/M-OPSIN } \\
(D 160)\end{array}$ & $\begin{array}{l}\text { (Wahlin et } \\
\text { al., 2017) }\end{array}$ \\
\hline
\end{tabular}


Table 2: Transplantation studies with retinal cells derived from mouse PSCs.

Retinal differentiation protocol used for generation of transplanted cells are indicated between brackets. D, day; ERG, Electroretinogram; m, mouse; MEA, Multi Electrode Array; ONL, Outer Nuclear Layer; SRS, subretinal space; WT, wild-type.

\begin{tabular}{|c|c|c|c|c|}
\hline Mouse PSC line used & Transplanted population & Host & $\begin{array}{l}\text { Injection route/ } \\
\text { Transplantation } \\
\text { results }\end{array}$ & References \\
\hline $\begin{array}{l}\text { dsRed-miPSCs } \\
\text { (Tucker et al. 2011) }\end{array}$ & $\begin{array}{l}\text { D33 differentiated cells } \\
\text { containing } 30 \% \text { of } \\
\text { undifferentiated cells. } \\
\text { Magnetic beads depletion } \\
\text { of SSEA1-expressing cells } \\
\text { prior to transplantation of } \\
250000 \text { cells }\end{array}$ & $\begin{array}{l}4 \text { to } 6 \text { week- } \\
\text { old } R h o^{-/-} \\
\text {mice }\end{array}$ & $\begin{array}{l}\text { Subretinal injection. } \\
6.4 \% \text { of integrated cells } \\
\text { within the outer nuclear } \\
\text { layer }(16000 \text { cells out } \\
\text { of } 250000) . \\
\text { ERG response and c-Fos } \\
\text { expression detected in } \\
\text { grafted eyes. }\end{array}$ & $\begin{array}{l}\text { (Tucker et al., } \\
\text { 2011) }\end{array}$ \\
\hline $\begin{array}{l}\text { mESCs } \\
\text { (Eiraku et al. 2011) }\end{array}$ & $\begin{array}{l}200000 \text { FAC-sorted } \\
\text { AAV2/9.RhoP.GFP+ rod } \\
\text { photoreceptors after } 26,29 \\
\text { or 34D of differentiation. }\end{array}$ & $\begin{array}{l}\text { Adult } \\
\text { Gnat1 } 1^{-/} \\
\text {mice. }\end{array}$ & $\begin{array}{l}\text { Subretinal injection via } \\
\text { trans-scleral route. } \\
0.3 \% \text { of integrated cells. }\end{array}$ & $\begin{array}{l}\text { (Gonzalez- } \\
\text { Cordero et al., } \\
\text { 2013) }\end{array}$ \\
\hline $\begin{array}{l}\text { Crx:GFP-mESCls } \\
\text { (Eiraku et al. 2011) }\end{array}$ & $\begin{array}{l}200000 \text { FAC-sorted } \\
\text { GFP }+ \text { photoreceptors after } \\
22,26 \text { or } 30 \mathrm{D} \text { of } \\
\text { differentiation }\end{array}$ & $\begin{array}{l}\text { Adult } \\
\text { NOD/SCID } \\
\text { mice }\end{array}$ & $\begin{array}{l}\text { Subretinal injection. } \\
800 \text { integrated cells } \\
(0.4 \%) .\end{array}$ & $\begin{array}{l}\text { (Decembrini et } \\
\text { al., 2014) }\end{array}$ \\
\hline $\begin{array}{l}\text { Rosa26.tdTomato/Rx: } \\
\text { GFP mESCs } \\
\text { Nrl:GFP miPSCs } \\
\text { (Eiraku et al. 2011) }\end{array}$ & $\begin{array}{l}\text { PSC-derived retinal sheets } \\
\text { at different time points of } \\
\text { differentiation (D11-D24) }\end{array}$ & $\begin{array}{l}6-8 \text { week- } \\
\text { old } R d 1 \\
\text { mice }\end{array}$ & $\begin{array}{l}\text { Subretinal injection via } \\
\text { trans-vitreal route. } \\
\text { Different graft } \\
\text { integration patterns, } \\
\text { maturation and } \\
\text { structural integrity } \\
\text { observed. } \\
\text { No difference between } \\
\text { miPSC and mESC- } \\
\text { derived grafts. }\end{array}$ & $\begin{array}{l}\text { (Assawachana } \\
\text { nont et al., } \\
\text { 2014) }\end{array}$ \\
\hline $\begin{array}{l}\text { CBA.YFP-mESCs } \\
\text { (Eiraku et al. 2011) }\end{array}$ & $\begin{array}{l}200000 \text { FAC-sorted rod } \\
\text { precursors selected at D27 } \\
\text { on their co-expression of } \\
\text { CD } 73, \text { CD24, CD133 and } \\
\text { CD } 47 \text { and absence of } \\
\text { CD15 expression }\end{array}$ & $\begin{array}{l}6-8 \text { week- } \\
\text { old WT or } \\
\text { Gnat1 } 1^{-/-} \\
\text {mice }\end{array}$ & $\begin{array}{l}\text { Subretinal injection via } \\
\text { trans-scleral route. } \\
\text { Higher integration levels } \\
\text { of sorted cells ( } 654 \\
\text { cells) compared to } \\
\text { unsorted cells ( } 9 \text { cells). }\end{array}$ & $\begin{array}{l}\text { (Lakowski et } \\
\text { al., 2015) }\end{array}$ \\
\hline $\begin{array}{l}\text { mESCs } \\
\text { (Eiraku et al. 2011) }\end{array}$ & $\begin{array}{l}200000 \text { CD } 73+\text { MAC- } \\
\text { sorted rod photoreceptors, } \\
\text { selected from D26 } \\
\text { organoids (pre-transfected } \\
\text { with AAV Rho-GFP) }\end{array}$ & $\begin{array}{l}\text { 7-12 week- } \\
\text { old WT, } \\
{\text { Prom } 1^{-/-}}_{\text {Cpfl/Rho-/- }} \\
\text { mice }\end{array}$ & $\begin{array}{l}\text { Subretinal injection via } \\
\text { trans-vitreal route. } \\
\text { Photoreceptors } \\
\text { transplanted in WT and } \\
\text { Prom } 1^{-/} \text {mice integrated } \\
\text { with similar efficiencies; } \\
\text { transplanted cells in } \\
\text { Cpfl/Rho/- did not }\end{array}$ & $\begin{array}{l}\text { (Santos- } \\
\text { Ferreira et al., } \\
\text { 2016b) }\end{array}$ \\
\hline
\end{tabular}


acquire mature

morphology. No

functionally recovery

detected by ERG.

200000 FAC-sorted

$\mathrm{GFP}+$ cells from D16 and D23 Crx-GFP organoids or D26-30

transfected organoids

200000 FAC-sorted

L/MOpsin.GFP+ cones

sorted from D26-30 AAV

ShH10.L/MOpsin.GFP

transfected organoids
AAV2/9.2.1.GFP

WT, DsRed and $\mathrm{Nrl}^{-/-}$

mice

WT and 8

week-old

Aipl1/- mice

Subretinal injection via

trans-scleral route.

Transplanted cells

within host SRS were

positive for cone

markers.

Subretinal injection via trans-scleral route.

$99 \%$ of GFP+/DsRed+

cells in DsRed

recipients; increased

number of GFP+ cells in

$\mathrm{Nrl}^{-/-}$host ONL

compared to WT

Subretinal injection via trans-vitreal route.

Nrl-GFP/

ROSA::Nrl-CtBP2-

D13 miPSC-derived

tdTomato miPSC line retinal sheets

(Eiraku et al. 2011)

L7-GFP/rd1 behavior and MEA
Light-avoidance

(Mandai et al.,

responses recorded in

some transplanted mice.
(Kruczek et

al., 2017)

(Waldron et

al., 2018) 
Table 3: Transplantation studies with retinal cells derived from human PSCs.

Retinal differentiation protocol used for generation of transplanted cells are indicated between

brackets. D, day; ERG, Electroretinogram; h, human; MEA, Multi Electrode Array; OCT,

Optical Coherence Tomography; ONL, Outer Nuclear Layer; RGCs, Retinal Ganglion Cells;

SRS, subretinal space.

\begin{tabular}{|c|c|c|c|c|}
\hline Human PSC line used & $\begin{array}{l}\text { Transplanted } \\
\text { population }\end{array}$ & Host & $\begin{array}{l}\text { Injection route/ } \\
\text { Transplantation results }\end{array}$ & References \\
\hline $\begin{array}{l}\text { hESCs } \\
\text { (Lamba et al. 2006) }\end{array}$ & $\begin{array}{l}\text { 3-week retinal } \\
\text { differentiated cells } \\
\text { GFP-labeled by } \\
\text { infection with } \\
\text { lentivirus. (hEFF1aP- } \\
\text { eGFP) or adenovirus } \\
\text { (CMVP-eGFP). } \\
\text { Transplantation of } \\
50 \text { to } 80000 \text { cells. }\end{array}$ & $\begin{array}{l}\text { Neonatal } \\
\text { (P0-P3) } \\
\text { and adult } \\
\text { Crx } x^{-/-} \text {mice } \\
\text { (cyclospori } \\
\text { ne } \\
\text { treatment) }\end{array}$ & $\begin{array}{l}\text { Intravitreal and subretinal (via } \\
\text { trans-scleral route) injections. } \\
3000 \text { GFP+ cells in recipient } \\
\text { ONL. } \\
\text { Small ERG response detected } \\
\text { in grafted eyes. }\end{array}$ & $\begin{array}{l}\text { (Lamba et } \\
\text { al., 2009) }\end{array}$ \\
\hline $\begin{array}{l}\text { hiPSCs } \\
\text { (Lamba et al. 2006) }\end{array}$ & $\begin{array}{l}4 \text { to } 8 \text { week retinal } \\
\text { differentiated cells } \\
\text { GFP-labeled with } \\
\text { lentivirus (IRBPP- } \\
\text { GFP). Transplantation } \\
\text { of } 50000 \text { FAC-sorted } \\
\text { GFP+ cells. }\end{array}$ & $\begin{array}{l}\text { WT mice } \\
\text { (cyclospori } \\
\text { ne } \\
\text { treatment) }\end{array}$ & $\begin{array}{l}\text { Subretinal injection via trans- } \\
\text { scleral route. } \\
\text { Only } \sim 50 \text { cells detected in } \\
\text { recipient ONL }\end{array}$ & $\begin{array}{l}\text { (Lamba et } \\
\text { al., 2010) }\end{array}$ \\
\hline $\begin{array}{l}\text { hESCs } \\
\text { (Hambright et al. 2012) }\end{array}$ & $\begin{array}{l}\text { Transplantation of } \\
50000 \text { unsorted cells } \\
\text { corresponding to } 50 \\
\text { day-old retinal } \\
\text { progenitors expressing } \\
\text { EFTFs, NESTIN and } \\
\text { TUJ1. }\end{array}$ & $\begin{array}{l}\text { WT mice } \\
\text { (no } \\
\text { immunosup } \\
\text { pression) }\end{array}$ & $\begin{array}{l}\text { Epiretinal and subretinal } \\
\text { (trans-vitreal route) injections. } \\
\text { Cells in SRS predominantly } \\
\text { RECOVERIN+ cells. } \\
\text { Epiretinally grafted cells did } \\
\text { not mature. Survival of the } \\
\text { xenograft correlated with the } \\
\text { integrity of the blood retinal } \\
\text { barrier. }\end{array}$ & $\begin{array}{l}\text { (Hambright } \\
\text { et al., 2012) }\end{array}$ \\
\hline $\begin{array}{l}\text { hESCs and hiPSCs } \\
\text { (Barnea-Cramer et al. } \\
\text { 2016) }\end{array}$ & $\begin{array}{l}\text { Transplantation of } \\
200000 \text { cells obtained } \\
\text { by dissociation of } \\
\text { photoreceptor } \\
\text { progenitor spheres } \\
\text { transduced with } \\
\text { adenovirus (GRK1- } \\
\text { GFP) }\end{array}$ & $\begin{array}{l}\text { WT and } \\
r d 1 \text { mice } \\
\text { aged 10-12 } \\
\text { weeks } \\
\text { (cyclospori } \\
\text { ne } \\
\text { treatment) }\end{array}$ & $\begin{array}{l}\text { Subretinal injection via trans- } \\
\text { scleral route. } \\
\text { On average } 6.45 \% \text { hESC- } \\
\text { derived cells and } 5.7 \% \text { hiPSC- } \\
\text { derived cells survived. } \\
\text { Improvement of optomotor } \\
\text { response in treated eyes but no } \\
\text { difference in light avoidance } \\
\text { response. }\end{array}$ & $\begin{array}{l}\text { (Barnea- } \\
\text { Cramer et } \\
\text { al., 2016) }\end{array}$ \\
\hline $\begin{array}{l}\text { Rx::Venus and } \\
\text { Crx::Venus hESC lines } \\
\text { (Kuwahara et al. 2015) }\end{array}$ & $\begin{array}{l}\text { hESC-derived retinal } \\
\text { sheets at different time } \\
\text { points of } \\
\text { differentiation (D50- } \\
\text { 120). }\end{array}$ & $\begin{array}{l}\text { NUDE and } \\
\text { NUDE } \\
\text { S334ter-3 } \\
\text { rats, } \\
\text { Monkey } \\
\text { damage- } \\
\text { induced }\end{array}$ & $\begin{array}{l}\text { Subretinal injection via trans- } \\
\text { vitreal route. } \\
\text { Grafts from D50 organoids } \\
\text { developed thicker ONLs than } \\
\text { those from D100 organoids. In } \\
\text { transplanted monkeys, no }\end{array}$ & $\begin{array}{l}\text { (Shirai et al., } \\
\text { 2016) }\end{array}$ \\
\hline
\end{tabular}




\begin{tabular}{|c|c|c|c|c|}
\hline & & $\begin{array}{l}\text { models } \\
\text { (cyclospori } \\
\text { ne } \\
\text { treatment) }\end{array}$ & $\begin{array}{l}\text { positive results obtained by } \\
\text { focal ERG. }\end{array}$ & \\
\hline $\begin{array}{l}\text { hES cells } \\
\text { (Lamba et al. 2006) }\end{array}$ & $\begin{array}{l}\text { Transplantation of } \\
500000 \text { - } 750000 \\
\text { retinal differentiated } \\
\text { cells GFP-labeled by } \\
\text { infection with } \\
\text { lentivirus. (hEFF1aP- } \\
\text { eGFP). }\end{array}$ & $\begin{array}{l}\text { 4-6 week- } \\
\text { old WT, } \\
I L 2 r \gamma^{-/-} \\
C r x^{t v r m 65} \\
I L 2 r \gamma^{-/-} \\
/ C r x^{t v r m 65} \\
\text { mice }\end{array}$ & $\begin{array}{l}\text { Subretinal injection via trans- } \\
\text { vitreal route. } \\
3 \text { months following } \\
\text { transplantation, robust } \\
\text { presence of GFP+ cells in } \\
I L 2 r \gamma^{-/} \text {mice (more than } \\
20000 \mathrm{GFP}+\text { cells on } \\
\text { average). } \\
\text { Pupillometry and ERG } \\
\text { response in } I L 2 r \gamma^{-/} / C r x^{t v r m 65} \\
\text { mice. }\end{array}$ & $\begin{array}{l}\text { (Zhu et al., } \\
\text { 2017) }\end{array}$ \\
\hline $\begin{array}{l}\text { hESCs and hiPSCs } \\
\text { (Gonzalez-Cordero et al. } \\
2017 \text { ) }\end{array}$ & $\begin{array}{l}\text { Labeling of L/M cones } \\
\text { by infection with } \\
\text { ShH10.L/Mopsin.GFP. } \\
\text { Transplantation of } \\
100 \text { 000 FAC-sorted } \\
\text { GFP+ cells. }\end{array}$ & $\begin{array}{l}\mathrm{Nrl}^{-/-} \text {and } \\
\text { Aipll-/- } \\
\text { mice (no } \\
\text { immunosup } \\
\text { pression). }\end{array}$ & $\begin{array}{l}\text { Subretinal injection. } \\
\text { Human cell mostly in SRS of } \\
\text { recipient retinas. } 30( \pm 34) \\
\text { GFP+ cells negative for } \\
\text { human-specific markers } \\
\text { detected in the ONL of } \mathrm{Nrl}^{-/-} \\
\text {mice. }\end{array}$ & $\begin{array}{l}\text { (Gonzalez- } \\
\text { Cordero et } \\
\text { al., 2017) }\end{array}$ \\
\hline $\begin{array}{l}\text { Crx::Venus hESC line } \\
\text { (Kuwahara et al. 2015) }\end{array}$ & $\begin{array}{l}\text { D64-66 hESC-derived } \\
\text { retinal sheets }\end{array}$ & $\begin{array}{l}\text { NOG- } \\
P d e 6 \beta^{r d 12 J / r} \\
d 1-2 J\end{array}$ & $\begin{array}{l}\text { Subretinal injection via trans- } \\
\text { vitreal route. } \\
\text { Long term survival ( } 20-27 \\
\text { weeks) and maturation of } \\
\text { transplants. Light responses } \\
\text { recorded by MEA from host } \\
\text { RGCs in } 3 \text { out of } 8 \text { grafted } \\
\text { retinas. }\end{array}$ & $\begin{array}{l}\text { (Iraha et al., } \\
\text { 2018) }\end{array}$ \\
\hline $\begin{array}{l}\text { hESCs } \\
\text { (Zhong et al. 2014) }\end{array}$ & $\begin{array}{l}\text { HESC-derived retinal } \\
\text { sheets at different time } \\
\text { points of } \\
\text { differentiation (D30- } \\
65 \text { ) }\end{array}$ & $\begin{array}{l}\text { NUDE } \\
\text { S334ter-3 }\end{array}$ & $\begin{array}{l}\text { Subretinal injection via trans- } \\
\text { scleral route. } \\
\text { OCT imaging showed long- } \\
\text { term transplant growth and } \\
\text { survival } \\
\text { up to } 10 \text { months post-surgery. } \\
\text { Visual improvements } \\
\text { measured by optokinetic } \\
\text { testing and electrophysiologic } \\
\text { recording in the superior } \\
\text { colliculus. }\end{array}$ & $\begin{array}{l}\text { (McLelland } \\
\text { et al., 2018) }\end{array}$ \\
\hline $\begin{array}{l}\text { hiPSCs } \\
\text { (Reichman et al. 2017) }\end{array}$ & $\begin{array}{l}\text { Unsorted and MAC- } \\
\text { sorted CD } 73+\text { cells } \\
\text { from D120 organoids. } \\
\text { Subretinal } \\
\text { transplantation of } \\
300000 \text { cells. }\end{array}$ & $\begin{array}{l}\text { NUDE rats, } \\
\text { P23H rats } \\
\text { (cyclospori } \\
\text { ne } \\
\text { treatment) }\end{array}$ & $\begin{array}{l}\text { Subretinal injection via trans- } \\
\text { vitreal route. } \\
\text { Human cell mostly in SRS of } \\
\text { recipient retinas up to } 2.5 \\
\text { months post-transplantation. }\end{array}$ & $\begin{array}{l}\text { (Gagliardi et } \\
\text { al., 2018) }\end{array}$ \\
\hline $\begin{array}{l}\text { hiPSCs } \\
\text { (Kuwahara et al. } \\
\text { 2015) }\end{array}$ & $\begin{array}{l}\text { hiPSC-derived retinal } \\
\text { sheets at different } \\
\text { time points of } \\
\text { differentiation (D50- } \\
\text { 120). }\end{array}$ & $\begin{array}{l}\text { NUDE } \\
\text { S334ter-3 } \\
\text { rats, } \\
\text { Monkey } \\
\text { damage- } \\
\text { induced } \\
\text { models } \\
\text { (cyclospor } \\
\text { ine } \\
\text { treatment) }\end{array}$ & $\begin{array}{l}\text { Subretinal injection via } \\
\text { trans-vitreal route. } \\
\text { Long term survival ( } 10 \\
\text { months) and maturation of } \\
\text { transplants. Light responses } \\
\text { recorded by MEA from host } \\
\text { rat RGCs. Mild recovery of } \\
\text { visually-guided saccade in } \\
\text { one monkey; no positive } \\
\text { results obtained by focal } \\
\text { ERG. }\end{array}$ & $\begin{array}{l}\text { (Tu et al., } \\
\text { 2019) }\end{array}$ \\
\hline
\end{tabular}




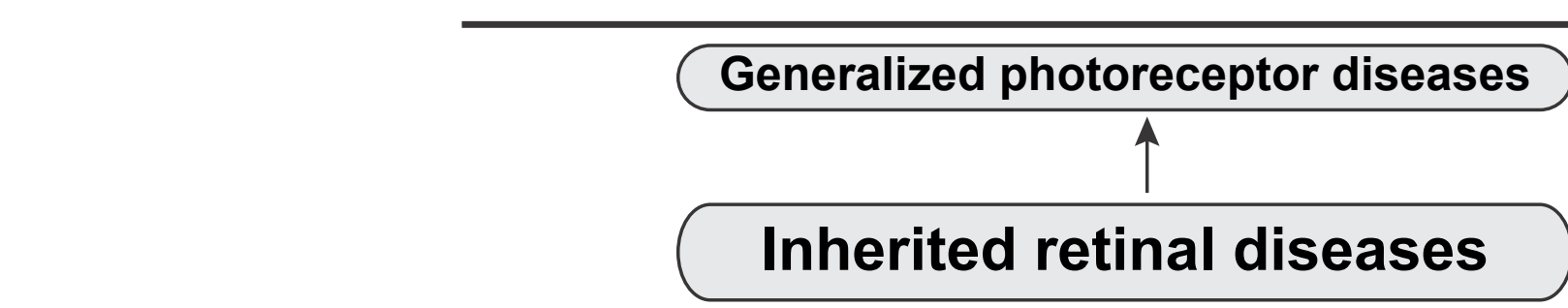

Syndromic

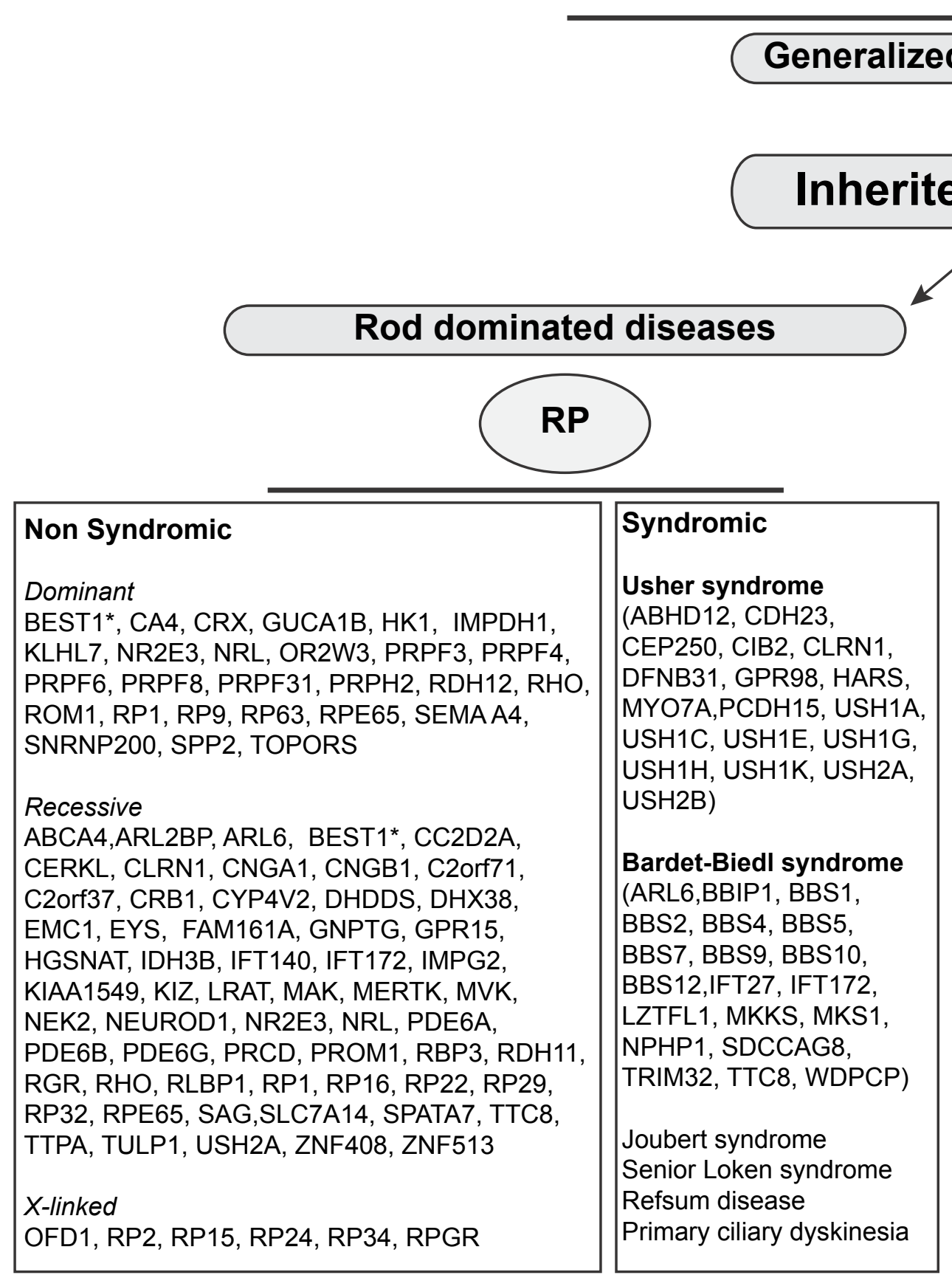

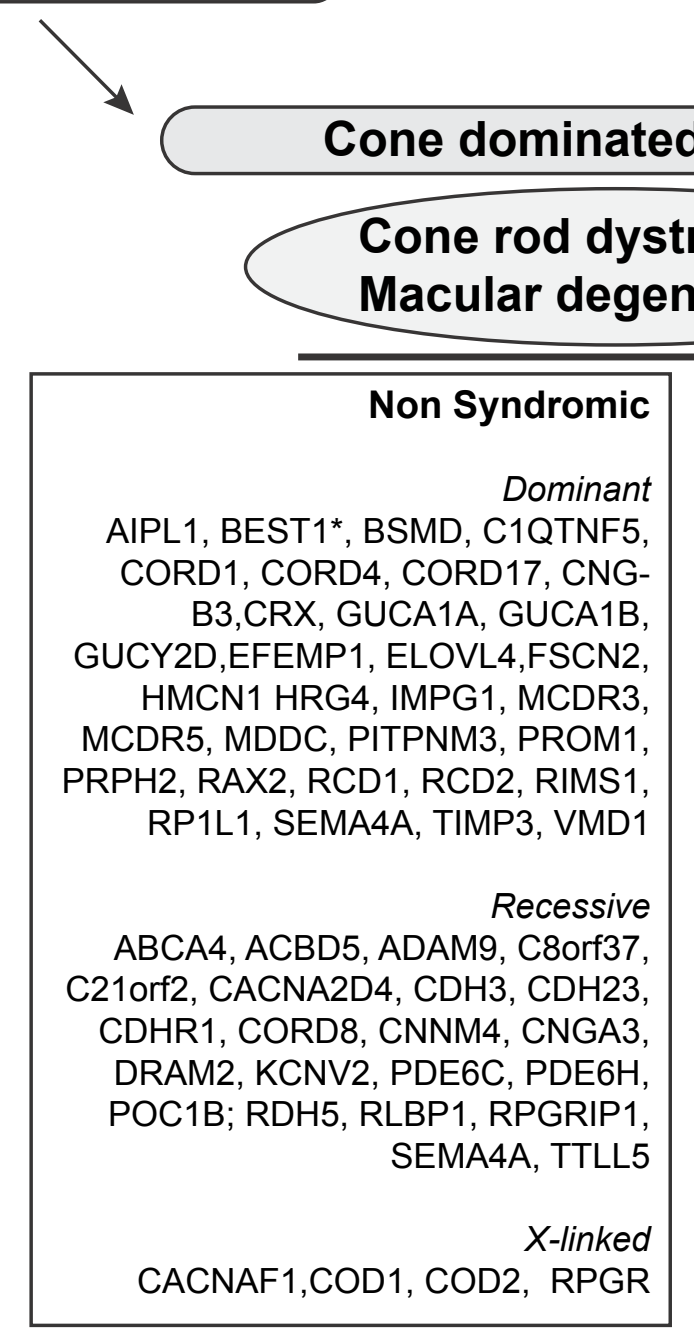




$$
\text { Q } \overline{D C} \mathrm{w}^{\prime}
$$




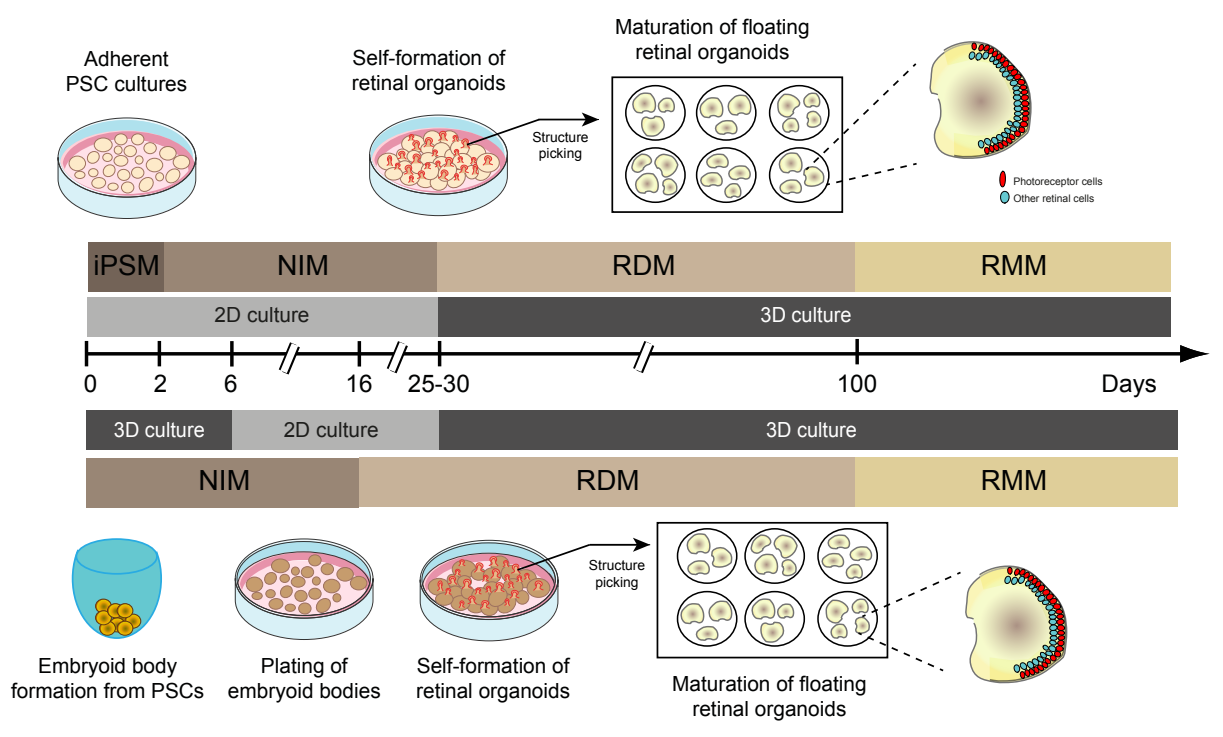



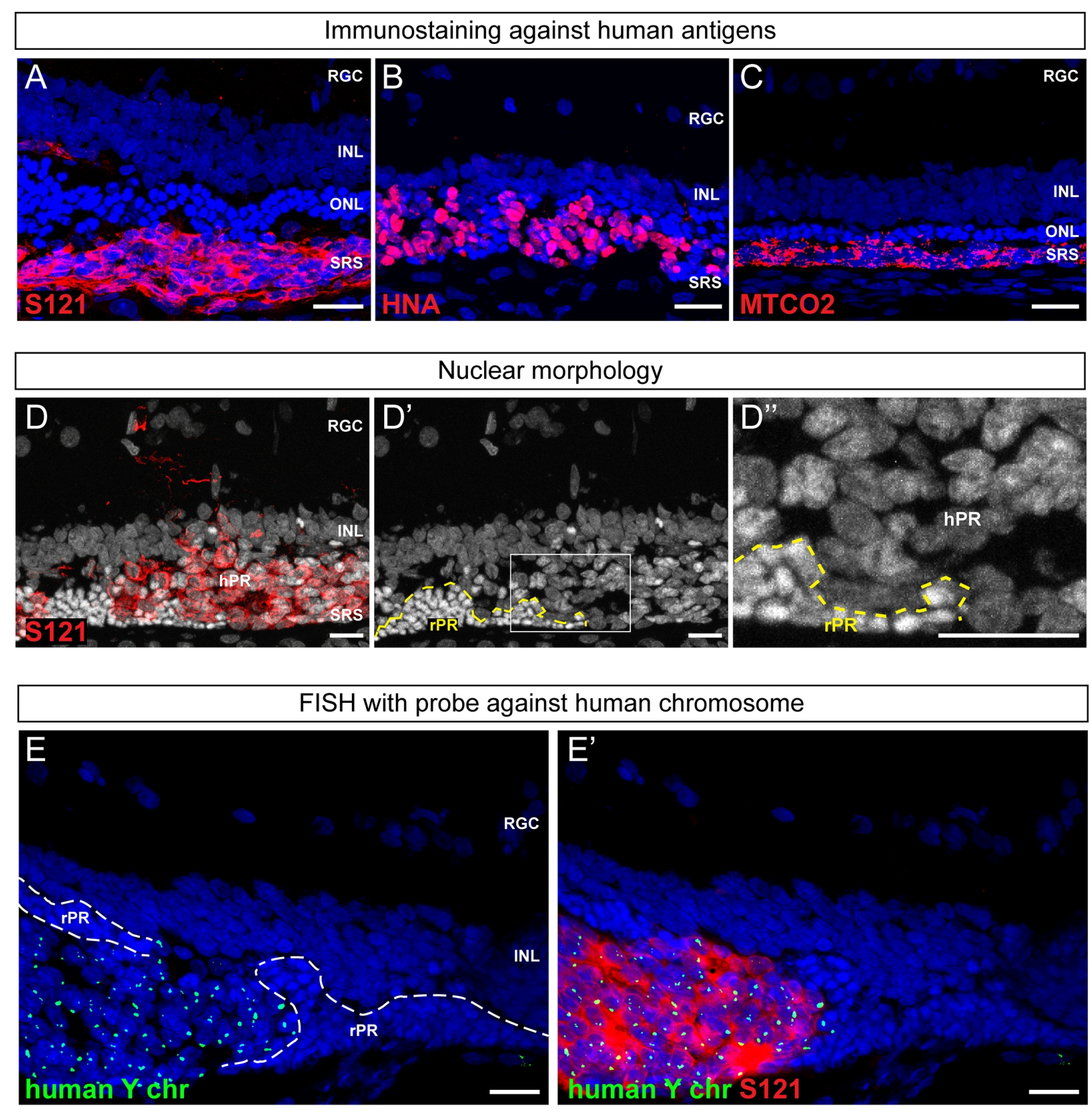
Cell product preparation

Observed/ expected subretinal transplantation outcome
- Photoreceptor cells

- Other retinal cells

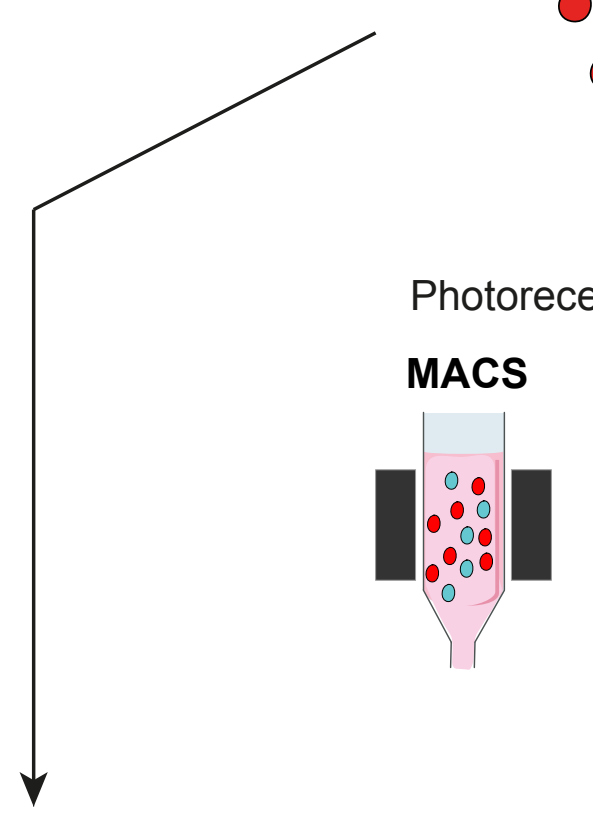

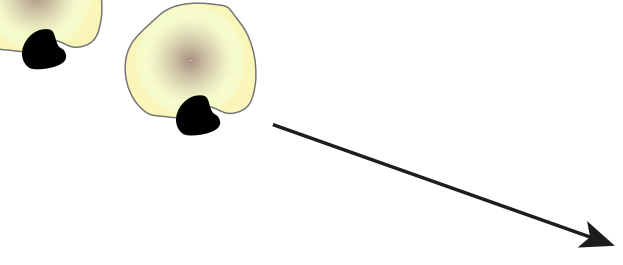

Retinal sheet

Cell suspension

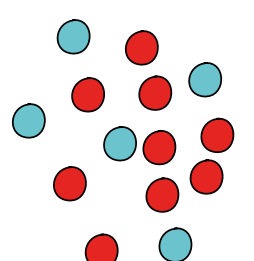

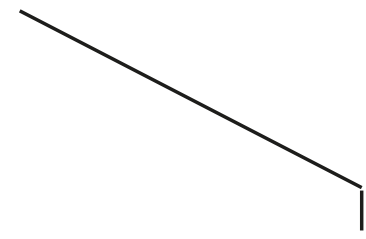

Inclusion / Bioprinting of photoreceptors on scaffold

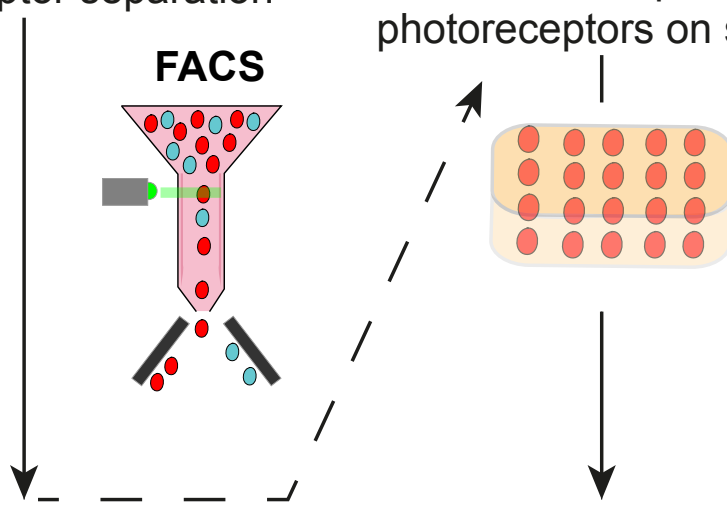

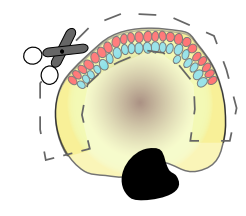

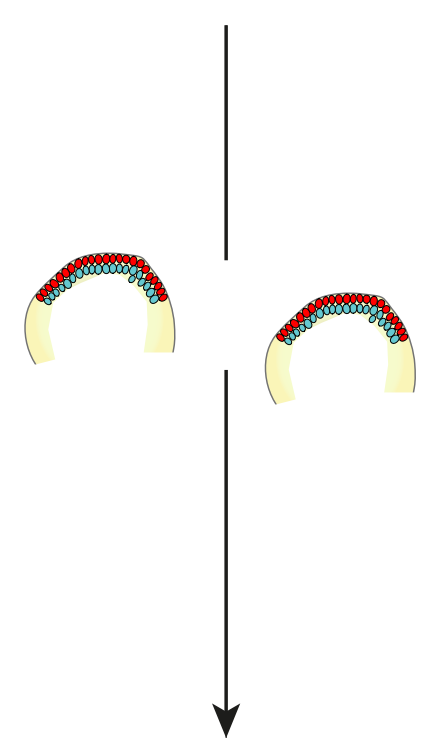

๑ 00 GCL $\infty 000$

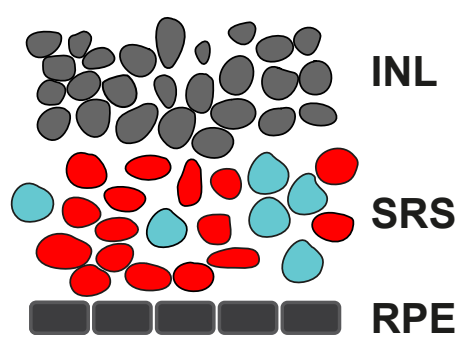

00000
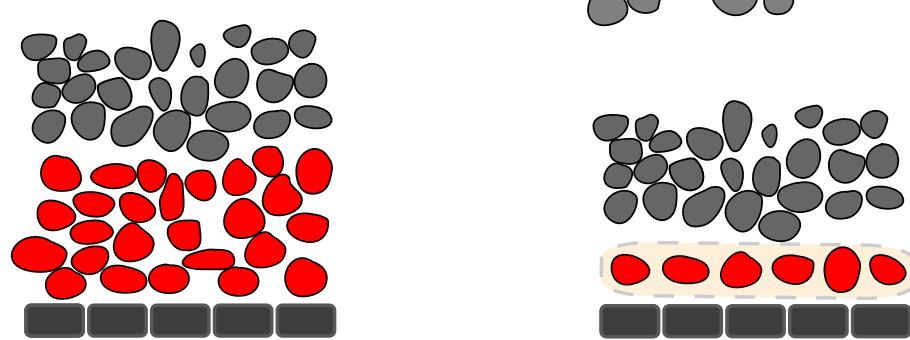

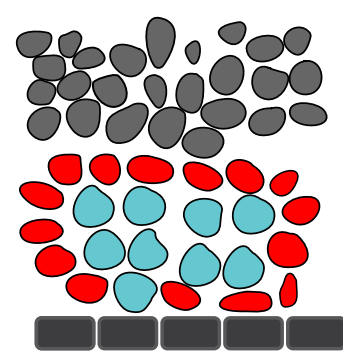

